Fall 1918

\title{
1918 Cedrus Yearbook
}

\section{Cedarville College}

Follow this and additional works at: https://digitalcommons.cedarville.edu/yearbooks

Part of the Higher Education Commons, Organizational Communication Commons, and the Public Relations and Advertising Commons

\section{Recommended Citation}

Cedarville College, "1918 Cedrus Yearbook" (1918). Yearbooks. 93.

https://digitalcommons.cedarville.edu/yearbooks/93

This Book is brought to you for free and open access by DigitalCommons@Cedarville, a service of the Centennial Library. It has been accepted for inclusion in Yearbooks by an authorized administrator of DigitalCommons@Cedarville. For more information, please contact digitalcommons@cedarville.edu. 


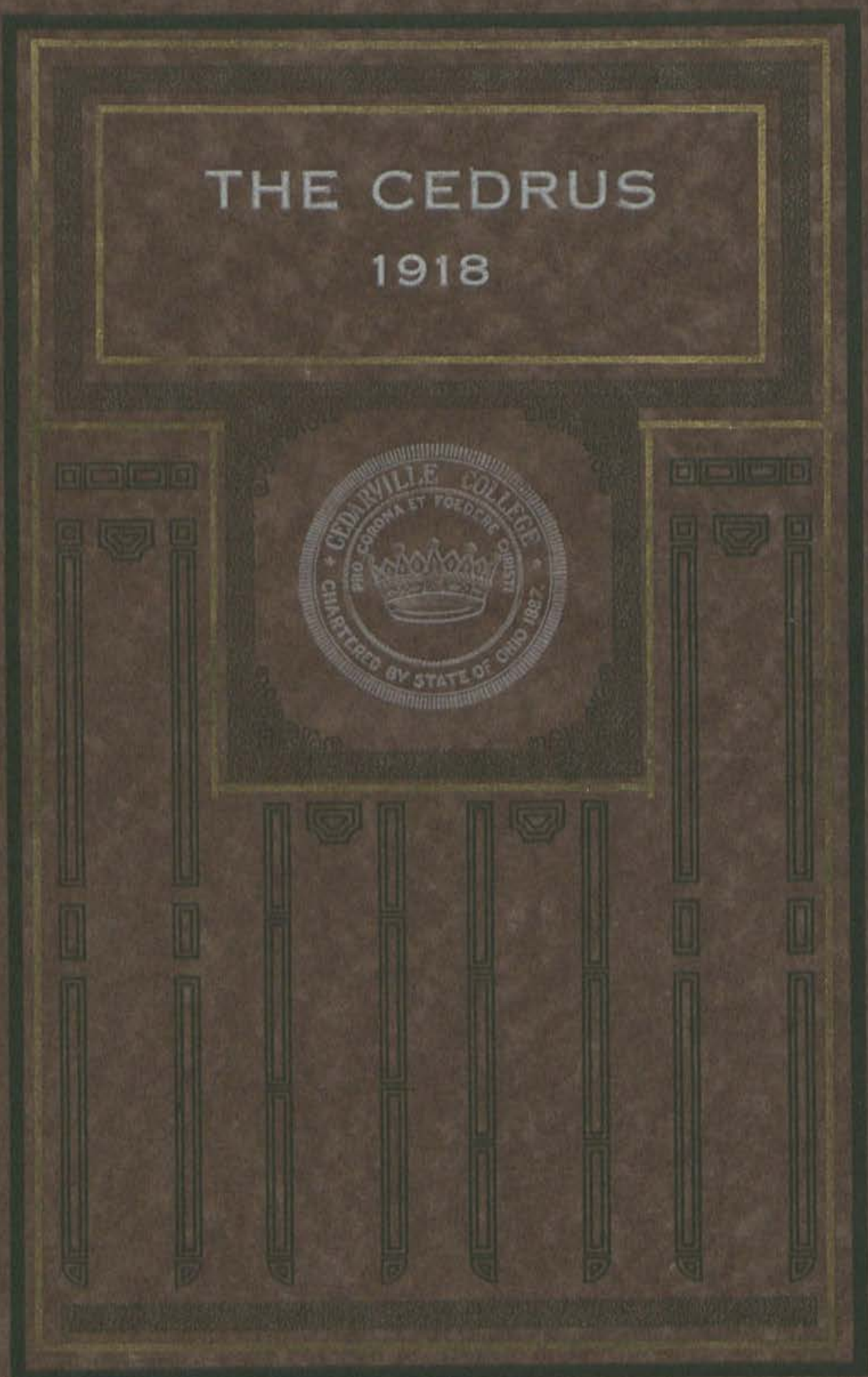




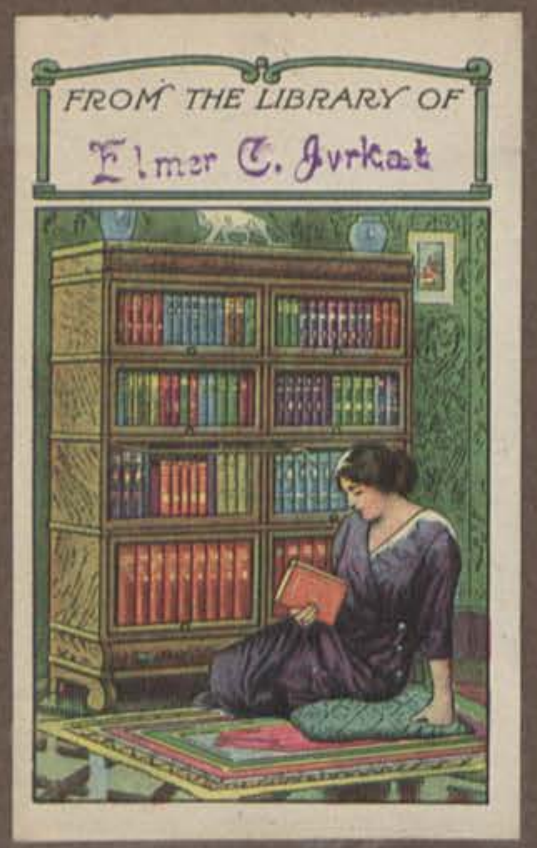



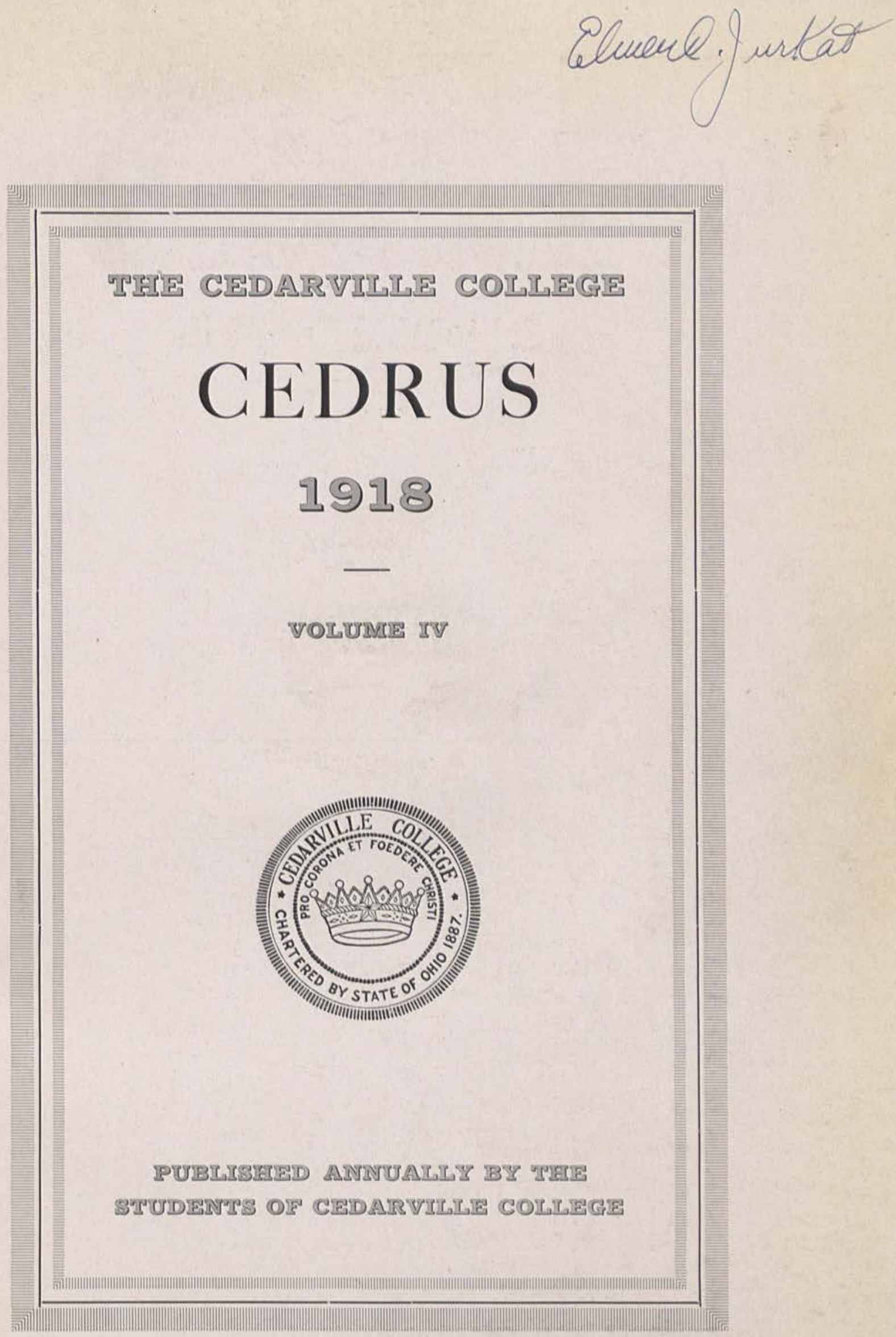



\section{Dedication}

MHIS Cedrus is dedicated with the Staff's best wishes and sincere regards to the young men of Cedarville College who have heard and heeded the call of the bugle and are now serving our country in various capacities. 

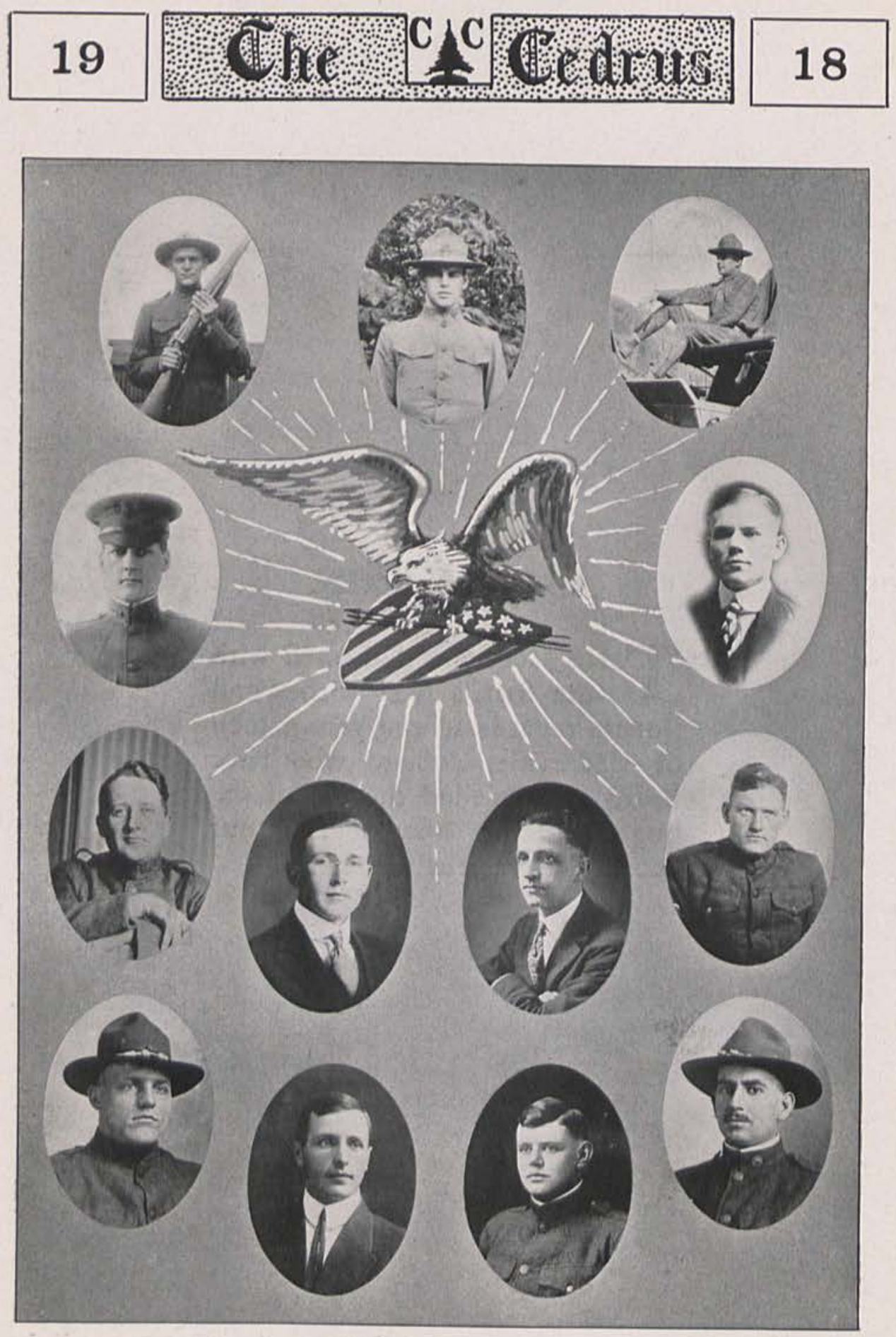

From left to right beginning with top row

1st row - John Wright Charles McClure Carl Duncan

2d row -J. Cecil George Paul Creswell

3d row-Homer Henderson Earl Short Fred Bird Charles Lowry 4th row - John Collins Hugh Turnbull David Bradfute Cameron Ross 

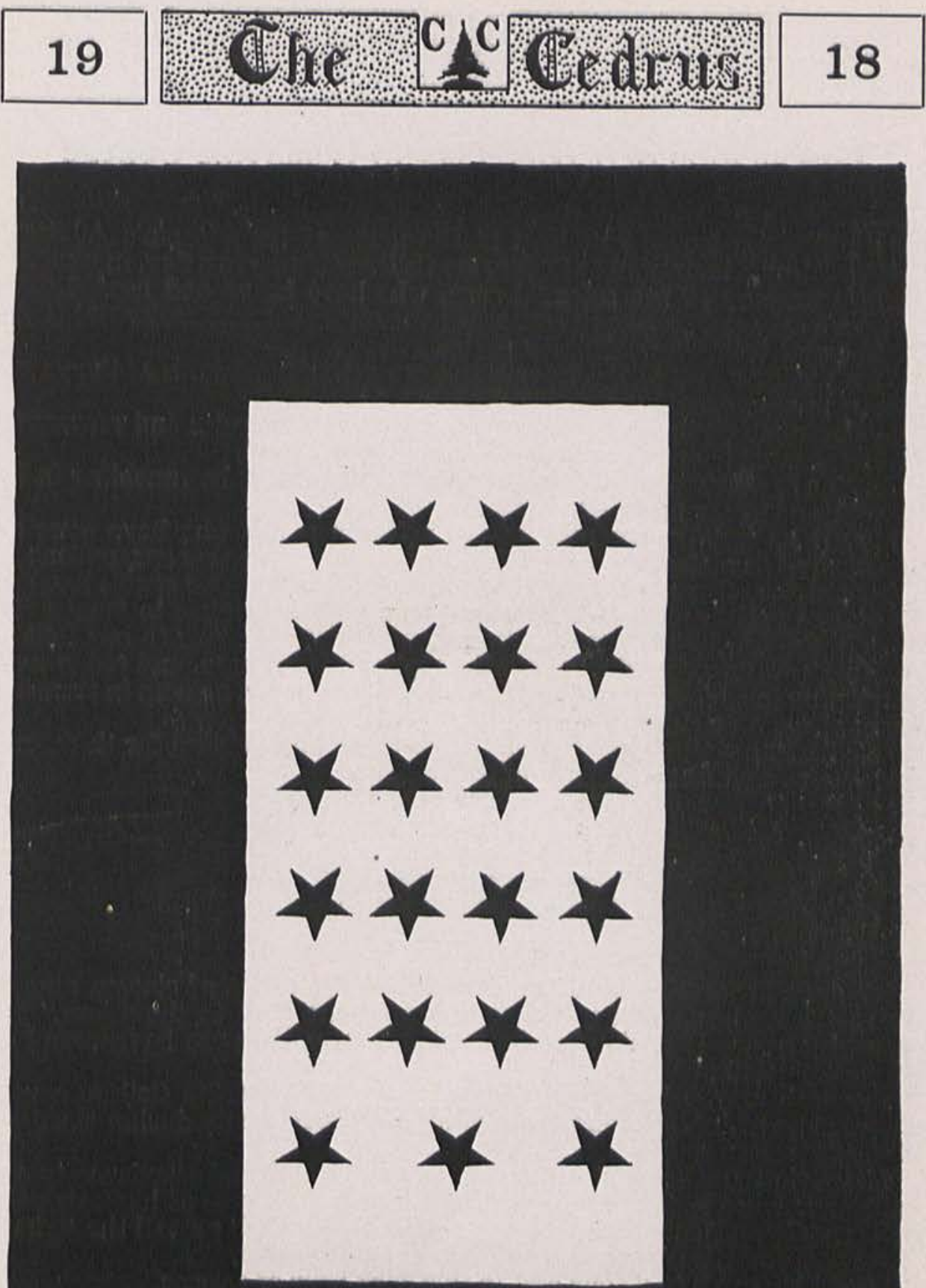


\section{9}

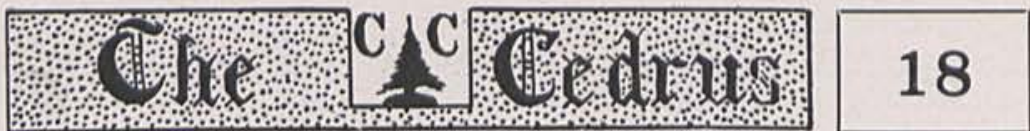

\section{Presentation of Service Flag to Cedarville College \\ Mary B. Ervin}

周

$\mathrm{T}$ is my happy privilege, in the name of the Women's Advisory Board, to present to Cedarville College this service flag, in precious memory of her splendid sons, who have heard and heeded their country's call, and today are serving in various capacities under Old Glory in the great war for world-wide peace.

This service flag typifies the courage, convictions and faith of the young men in whose honor it is presented at this time.

Each star is symbolic of service, sacrifice and surrender and represents a life dedicated to one's country and to humanity's need.

As this flag hangs within these College halls, may it be ennobling in its purpose and inspiring in its effect.

May it be a daily reminder of the splendid youth who have gone on in our stead to make the world safer for us and for coming generations.

Service for others is the spirit of the hour! As the war clouds hang so heavy, may this service flag intensify our zeal in helping to "make the world more bright" by sending messages and bits of cheer to our fellowstudents and friends, who have left home and loved ones, and today may be training in camps, or sailing on seas, or flying in air, or deep in trenches "somewhere over there."

Let them know that we are thinking of them, and praying for them, and that we are singing to the tune of America:

"God bless our splendid men,

Bring them safe home again,

God bless our men.

Keep them victorious,

Patient and chivalrous,

They are so dear to us,

God bless our men."

We proudly inscribe upon our Honor Roll the names of sixteen sons of Cedarville College who have already heeded the "call to the colors," for each of whom a blue star has been placed upon the pure background of white with its border of red.

For each new enlistment from the ranks of Cedarville College a new star will be added-binding the kindred ties more firmly during the dark days of separation.

May we pledge anew this day our loyalty to God and allegiance to our country and appreciate the blessed privilege that is ours of hastening the day when truth shall triumph, when righteousness shall prevail throughout the world, and when peace and sobriety shall reign supreme.

"God help us all to do our best in this dark hour of sorrow,

And grant that soon the night will pass and bring a bright tomorrow.

Then when the conflict's over and peace returns at last,

And the Hohenzollern menace is a relic of the past,

We'll free the U. S. Eagle for a fly around the world,

In every land, on every coast, our flag will be unfurled.

We'll lead the world-wide chorus in a song of Liberty,

We'll sound the note of freedom in a new Democracy.

The 'Brotherhood of Nations' will have won the right of way-

The truest, noblest type of which will be found in the U. S. A." 


\section{9}
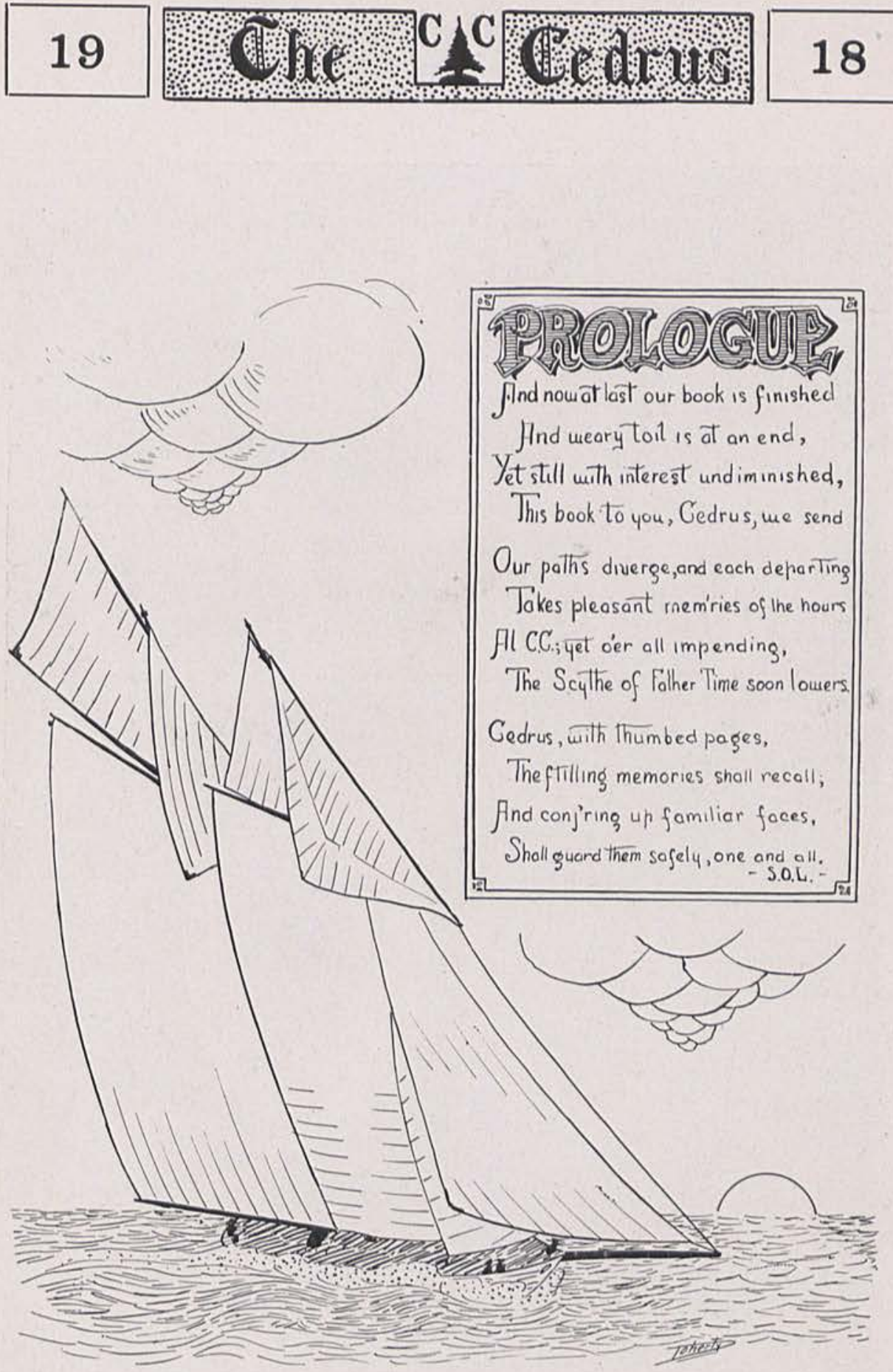


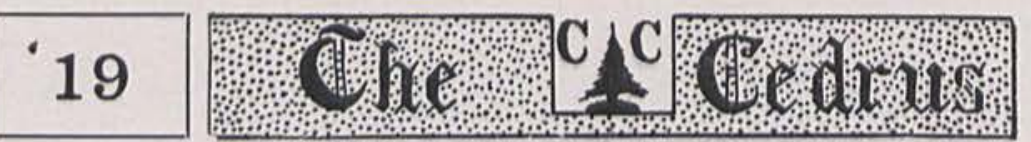

18

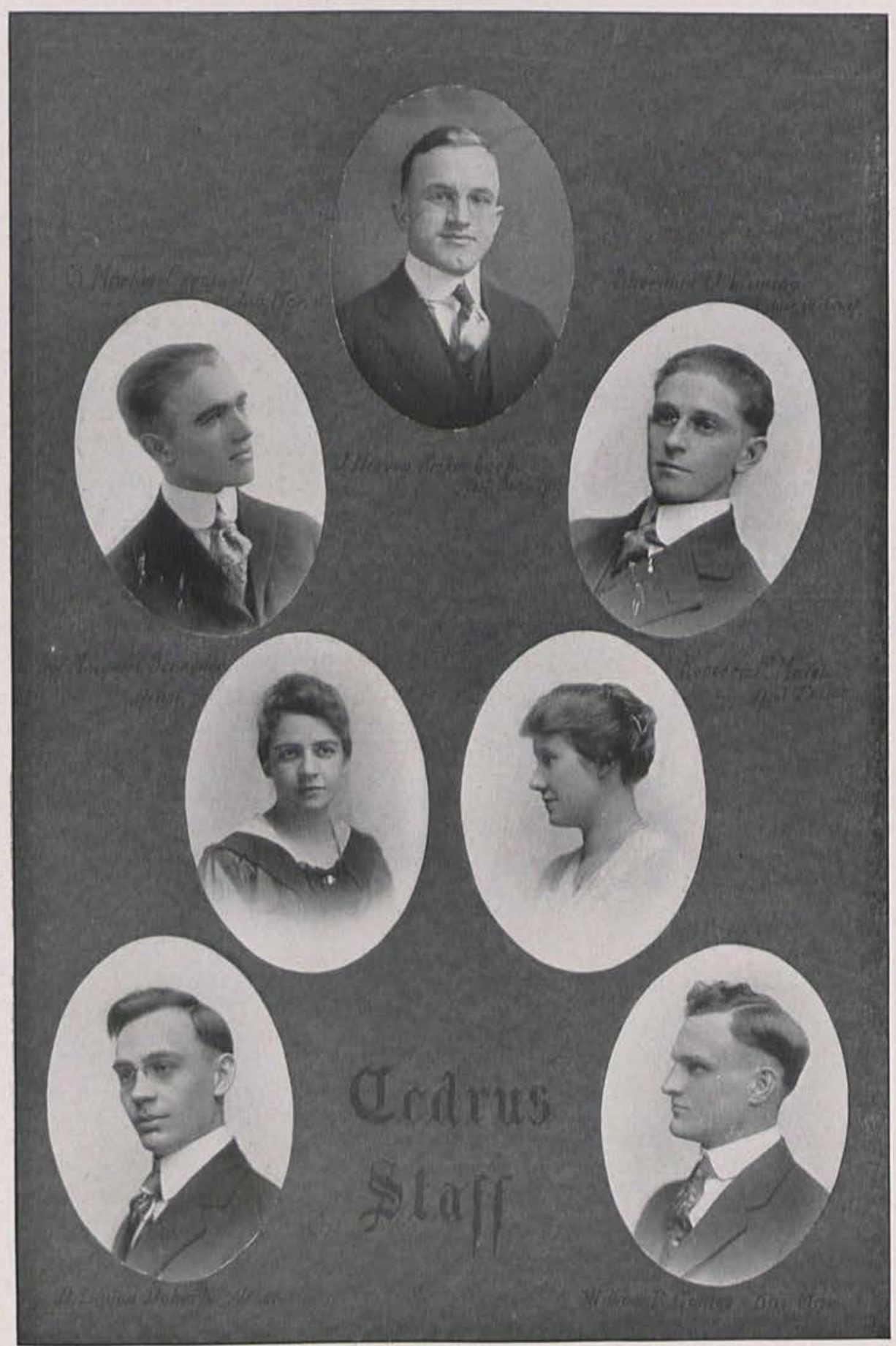




\section{9

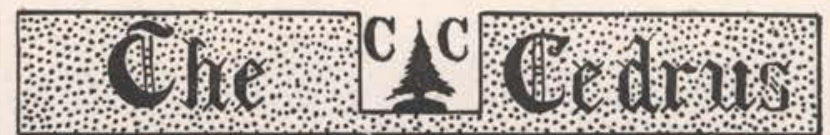 \\ 18}

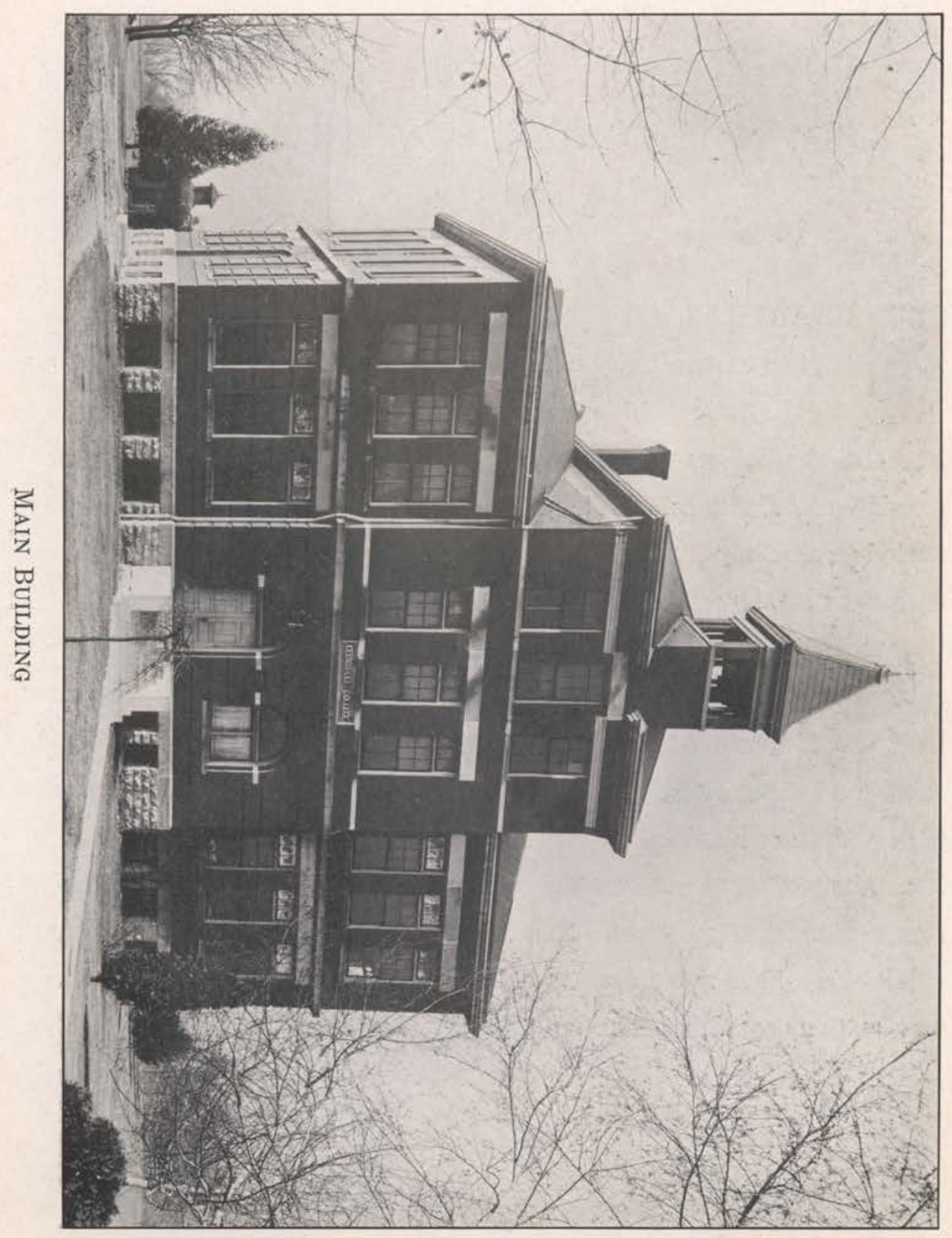




\section{9}

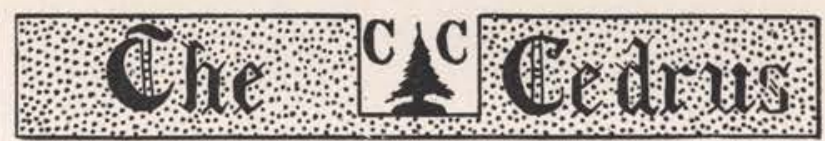

\section{HISTORICAL STATEMENT}

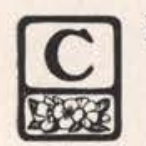

EDARVILLE COLLEGE is under the control of the General Synod of the Reformed Presbyterian Church. It was chartered by the State of Ohio in January, 1887. On Wednesday, September 19,1894 , the College was opened for instruction in the mansion formerly owned by Rev. Hugh McMillan, D. D., where, half a century ago, he conducted an academy from which many noted persons graduated. The accommodations not being sufficient for the needs of the growing institution, in the second year the present main building was erected and opened on the site purchased several years before. Both the buildings and the campus are the gifts of generous friends. Though young, the College has already exerted a lasting and wide-felt influence. Its students and graduates take high rank in seminaries, universities and other advanced schools of learning. Many of them are worthily filling positions of power and influence in America and foreign lands. And in the last two years the men of Cedarville College have nobly answered the call of their country, and are now serving their country's standards. 


\section{9}

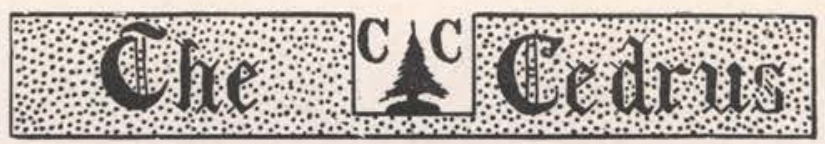

\section{BOARD OF TRUSTEES}

\section{CLASS OF 1918}

*Rev. J. L. Chesnut, D. D., Secretary_______arville, Ohio Prof. Frank A. Jurkat, A M., LL. D., Treasurer______Cedarville, Ohio Nathan L. Ramsey _._._._Cedarville, Ohio Joseph A. Finney, A. B., '06, Second Vice President_ Xenia, Ohio

\section{CLASS OF 1919}

James H. Creswell Cedarville, Ohio

Rev. Robert Boyd Wilson, A. B., '01 Jacksonville, Ill.

Rev. Homer McMillan, D. D., '97 Atlanta, Ga. Rev. David McKinney, D. D., LL. D. Cincinnati, Ohio

\section{CLASS OF 1920}

Rev. William R. Graham, A. B., '05, President Oscar E. Bradfute Rockville, Ind. Rev. W. R. McChesney, Ph. D., D. D. Xenia, Ohio

S. C. Wright, A. B., '03, First Vice President. Cedarville, Ohio Cedarville, Ohio

\section{STANDING COMMITTEES OF THE BOARD}

Executive-Chesnut, McChesney, Bradfute, Graham.

Finance-Creswell, Finney, Wilson, Ramsey.

Instruction-Chesnut, McMillan, McChesney, Wilson.

Property_Bradfute, Jurkat, Ramsey, Wright.

Auditing-Finney, Wright, McMillan, Ramsey.

Investment_Jurkat, McKinney, Bradfute, McChesney.

\section{LOCAL ADVISORY BOARD}

D. S. Ervin, J. C. Stormont, Thompson Crawford, G. E. Jobe, Oscar Smith, William Conley.

\section{WOMEN'S ADVISORY BOARD}

Miss Mary Ervin, Mrs. S. T. Baker, Mrs. John W. Johnson, Mrs. W. H. Barber, Mrs. W. R. McChesney, Mrs. Anderson Collins, Mrs. E. C. Oglesbee, Mrs. J. W. Dixon, Mrs. G. H. Creswell, Mrs. Leroy Allen, Mrs. L. D. Parker, Mrs. S. C. Wright.

*Died Feb. 7, 1918. 


\section{9}

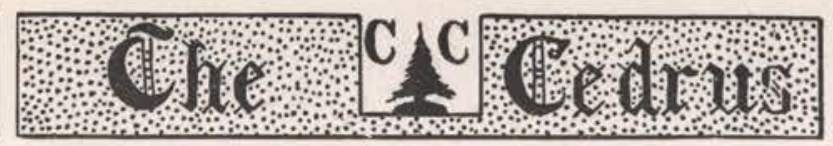

18

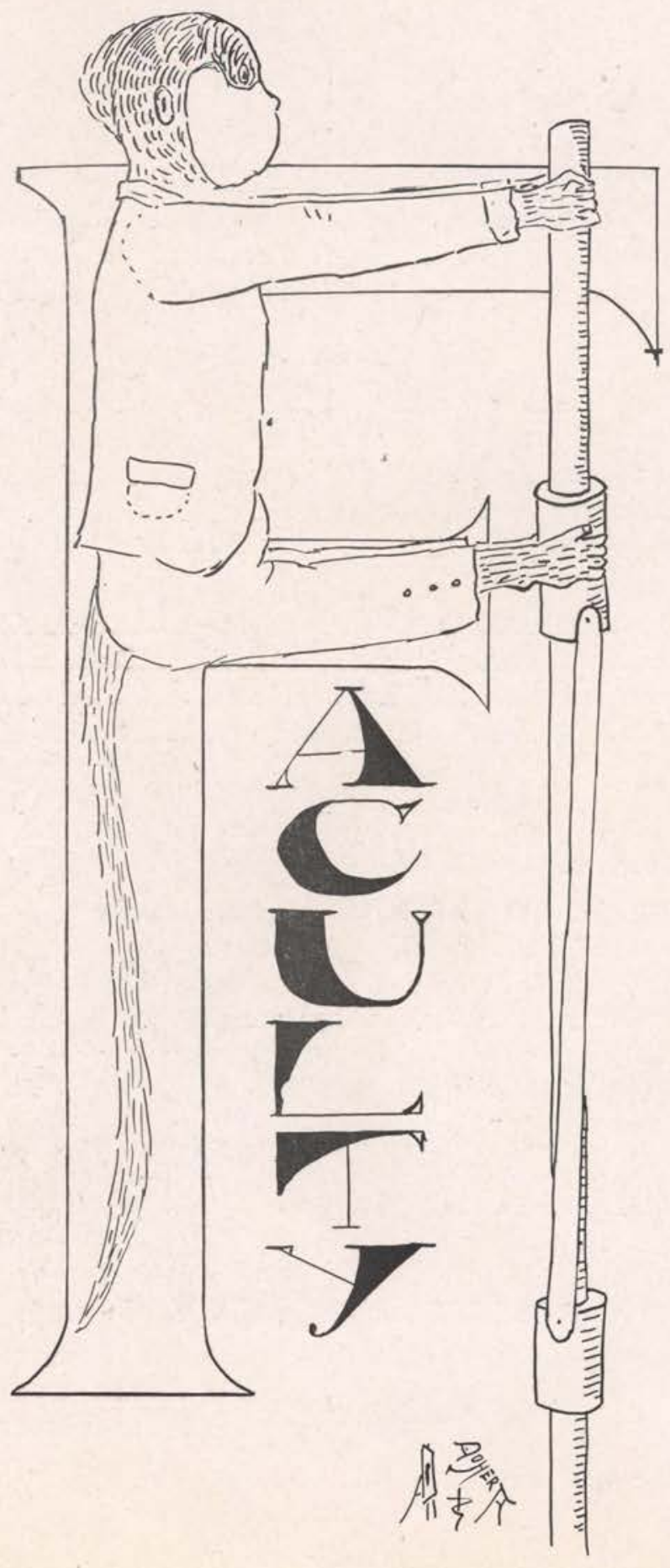



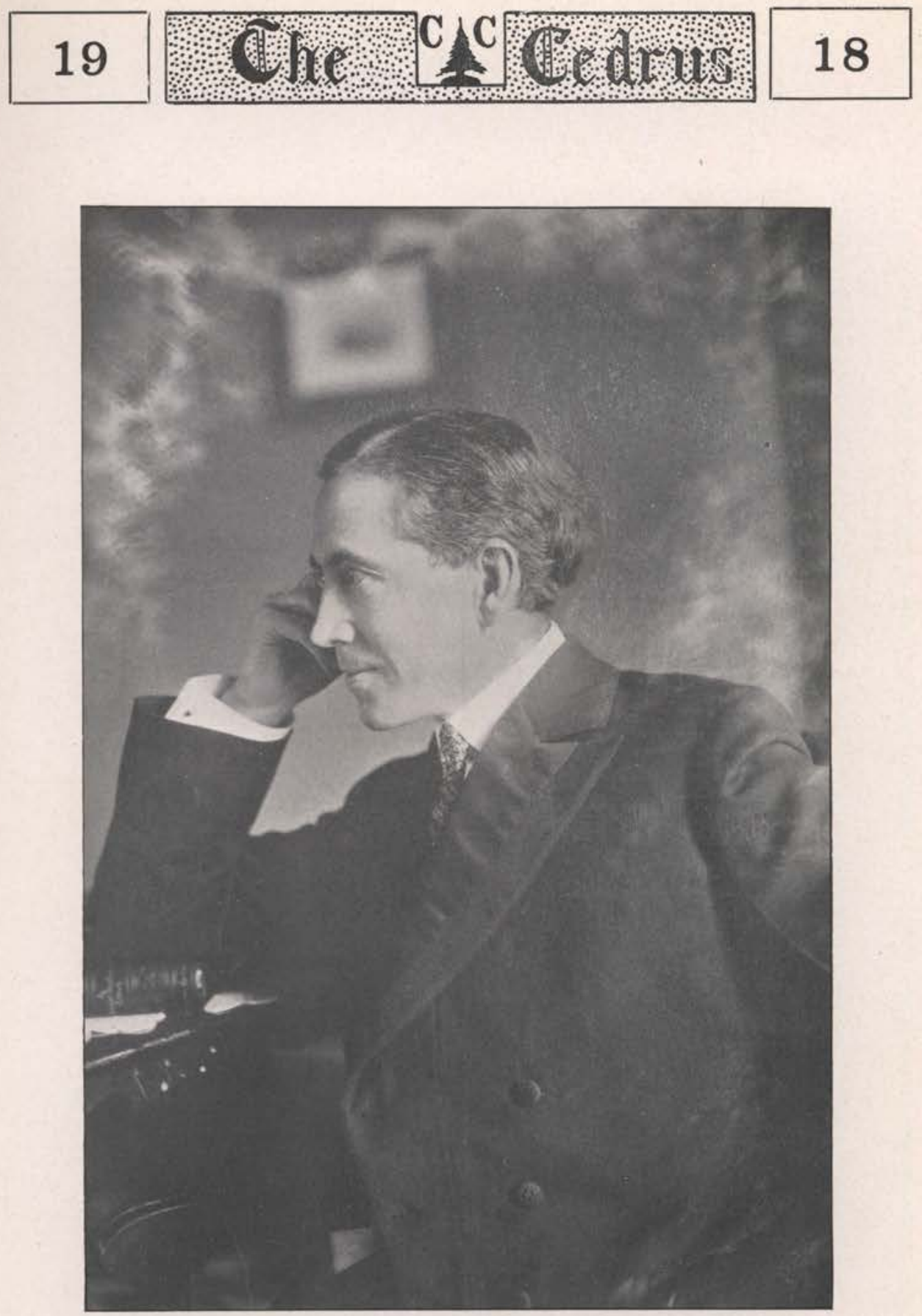

W. Renwick McChesney, Ph. D., D. D. President

Professor of Psychology, Oratory and Greek 


\section{9}
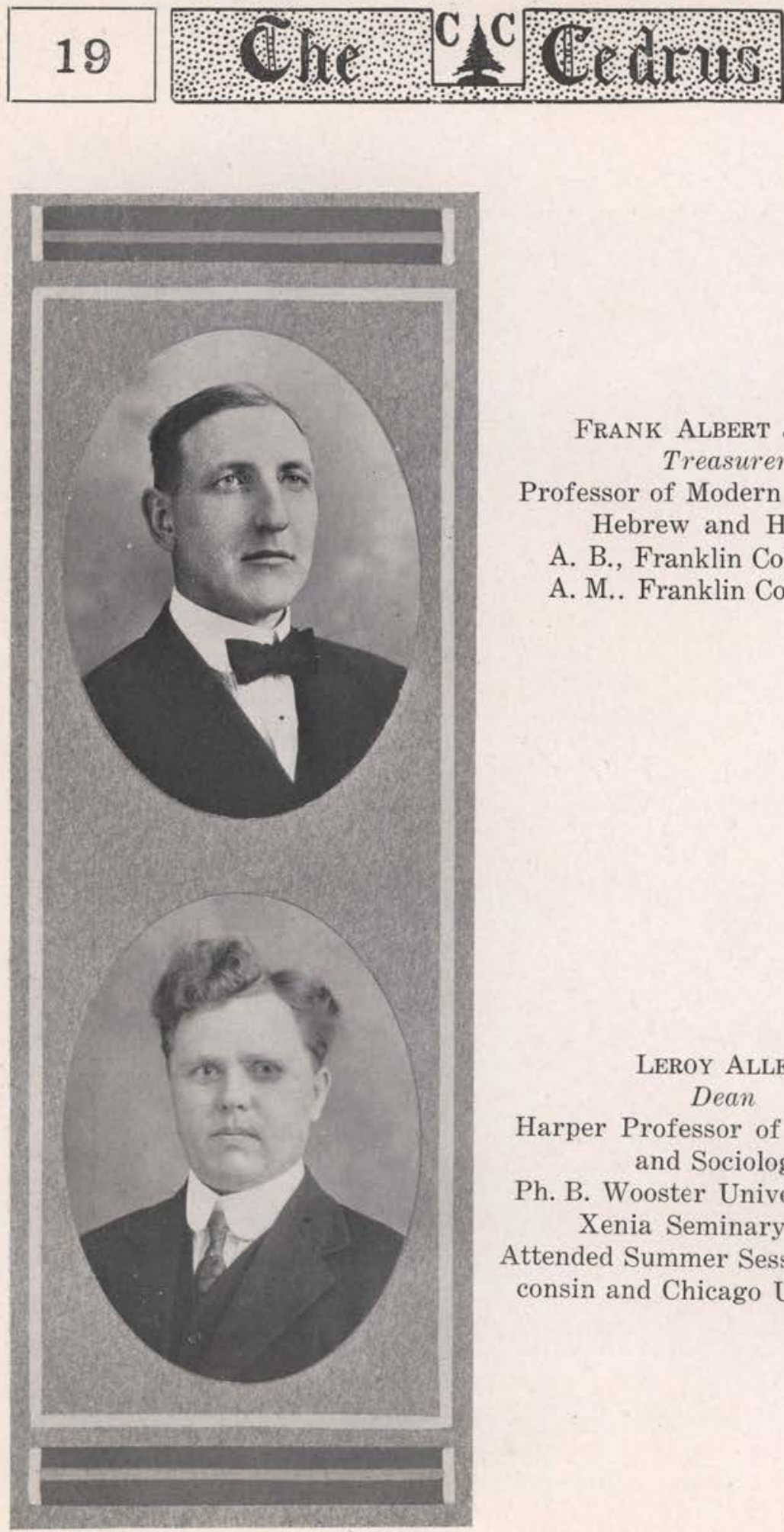

Frank Albert JuRkat

Treasurer

Professor of Modern Languages,

Hebrew and History

A. B., Franklin College 1895

A. M.. Franklin College 1898

\section{LEROY ALLEN \\ Dean}

Harper Professor of Economics and Sociology

Ph. B. Wooster University 1906

Xenia Seminary 1914

Attended Summer Sessions at Wisconsin and Chicago Universities 
AnNa MaRgaret SchneDER Professor of English and German A. B., Oberlin College 1913

Helen Pauline Oglesbee Director of the Department of Music

A. B., Cedarville College 1918 Graduate of Department of Music in Cedarville College 1914

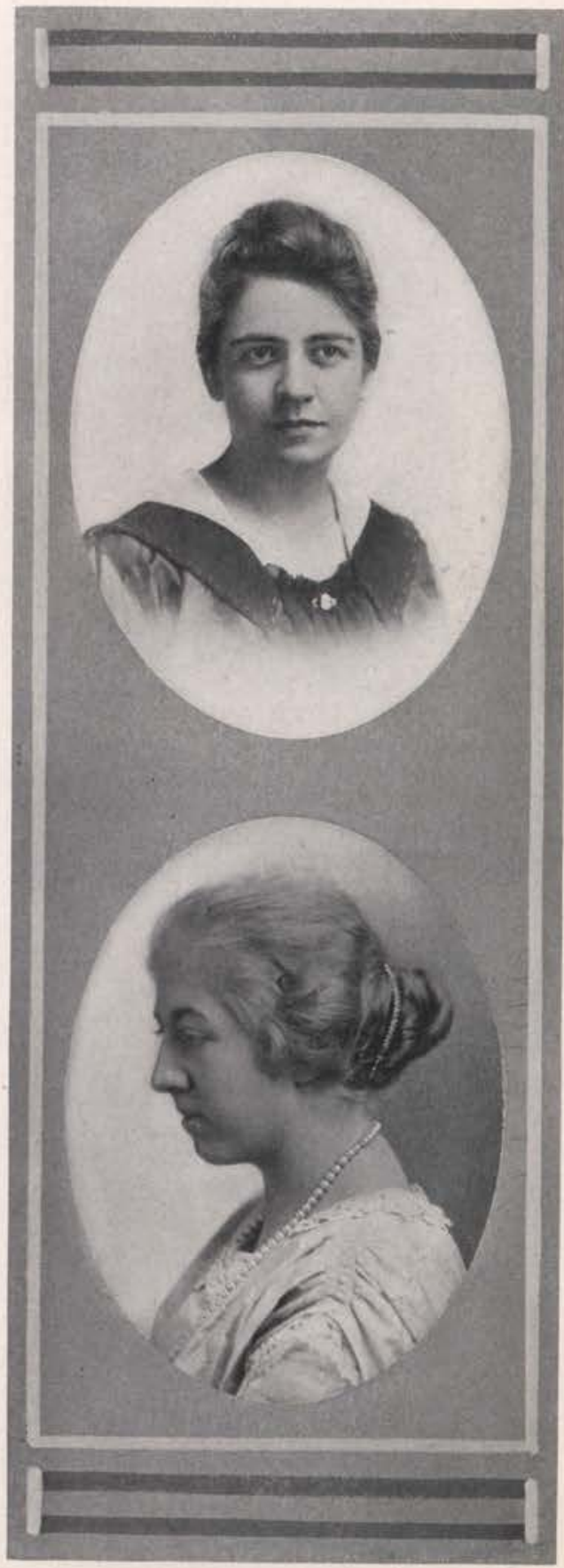



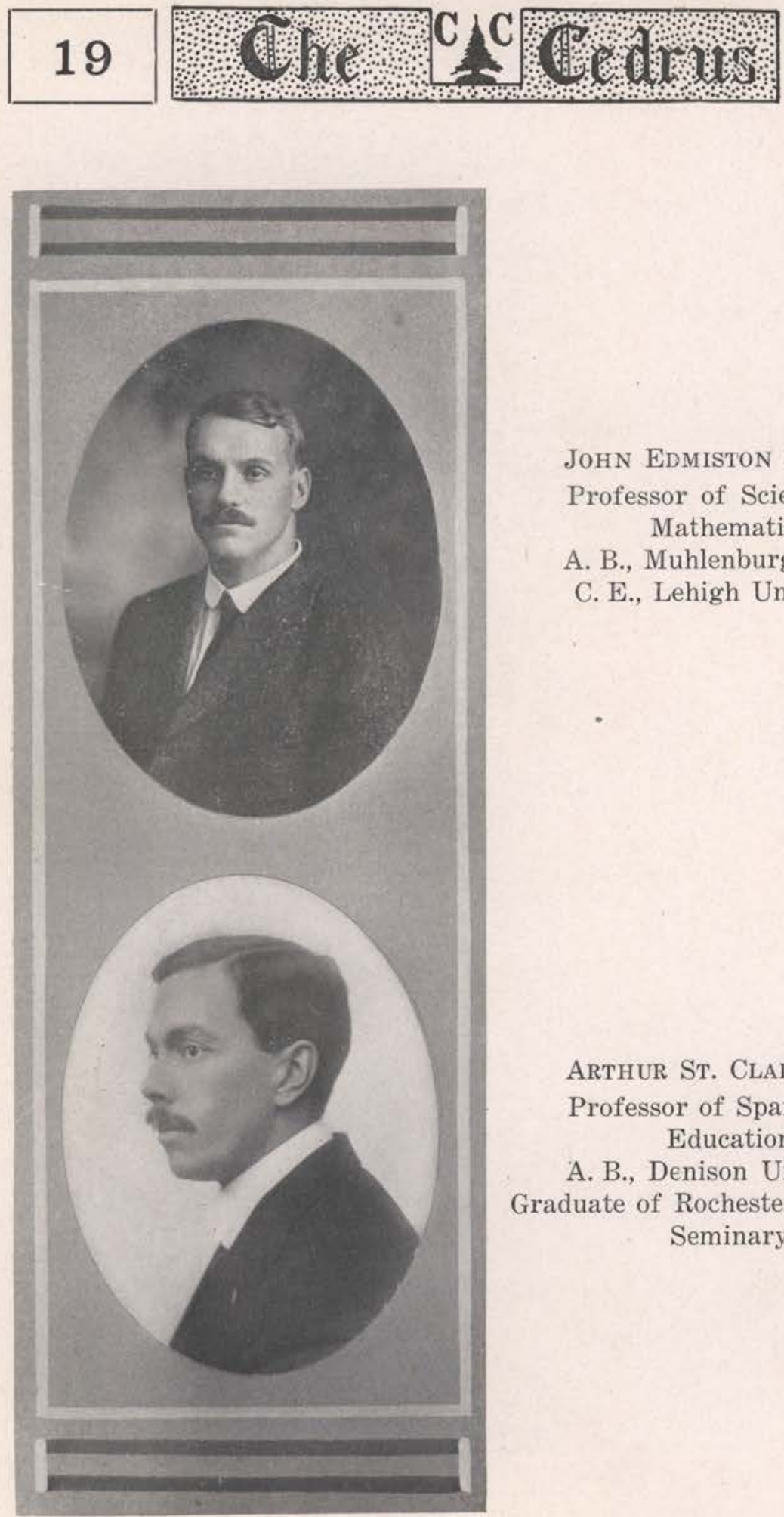

JoHN EDMiston BAUMAN

Professor of Science and Mathematics

A. B., Muhlenburg College

C. E., Lehigh University

Arthur St. Clair Sloan

Professor of Spanish and Education

A. B., Denison University

Graduate of Rochester Theological

Seminary 


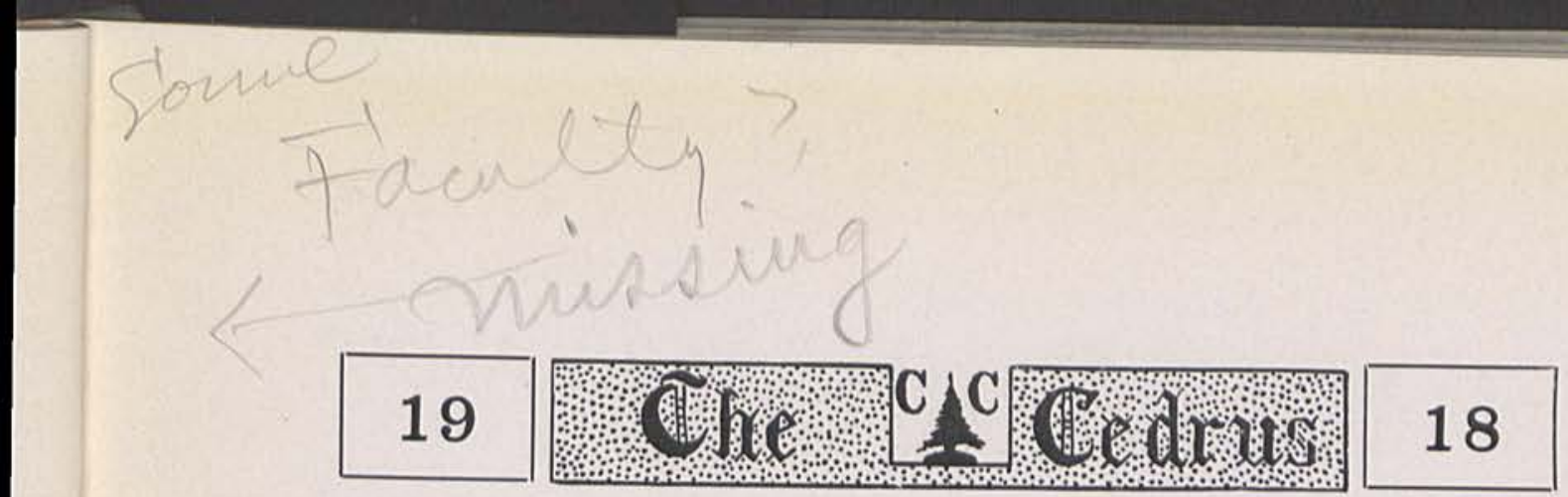

MRS. W. H. MCGERVEY

Instructor in Vocal Music

RALPH Stuart Elder

Secretary to the President and to the Dean

Instructor in Greek

A. B., Cedarville College

A. M., Cedarville College

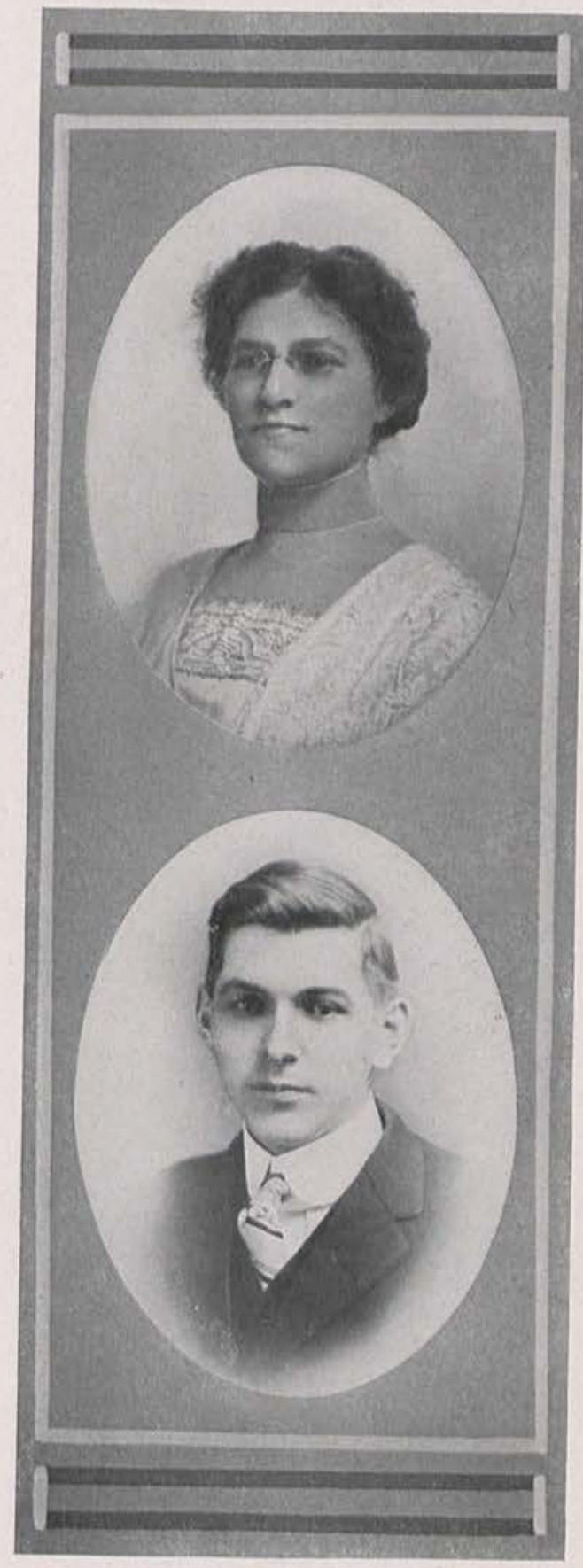



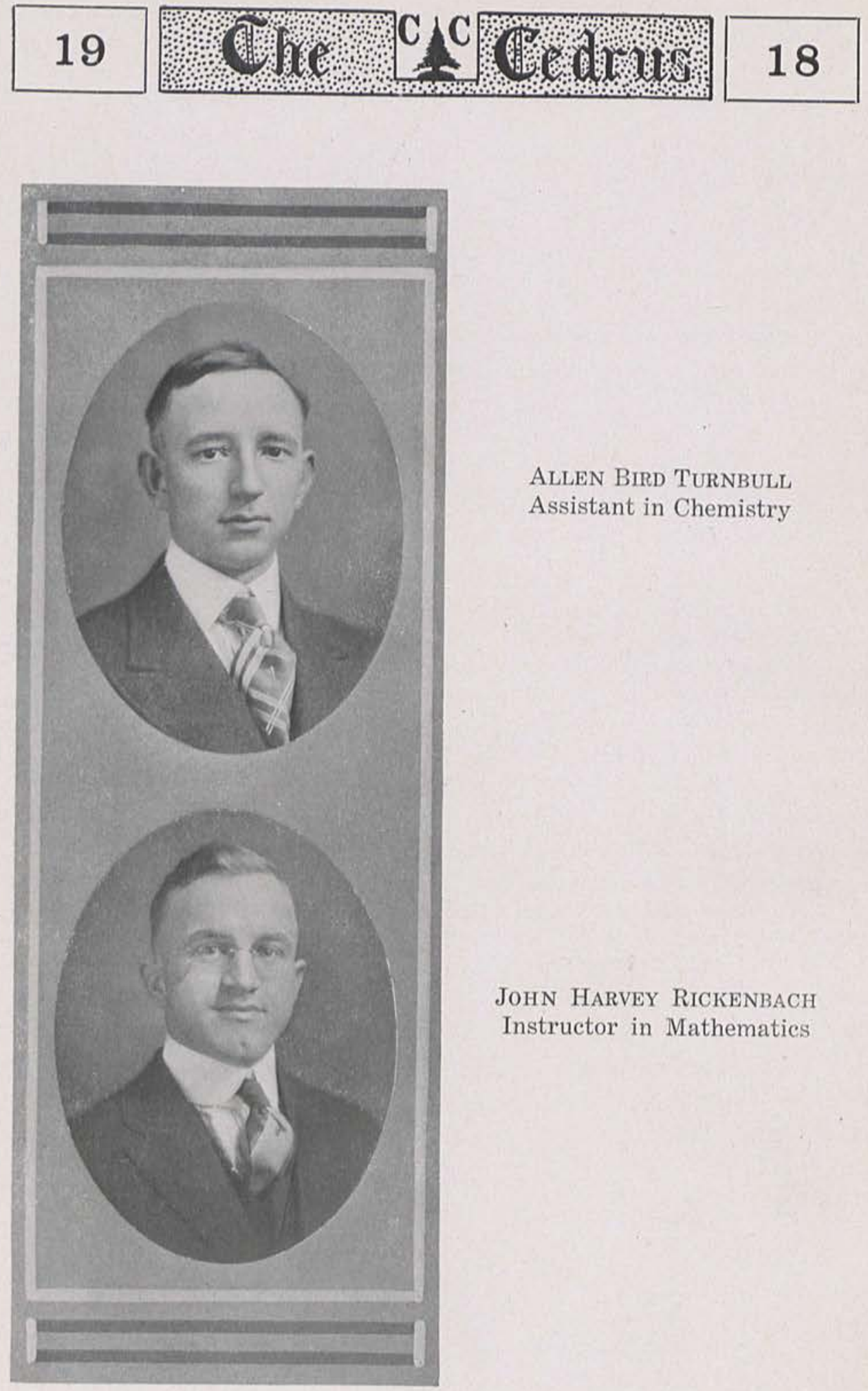

Allen Bird Turnbull Assistant in Chemistry

JOHN HARVEY RICKENBACH Instructor in Mathematics 


\section{9 ard ACAnus 18}

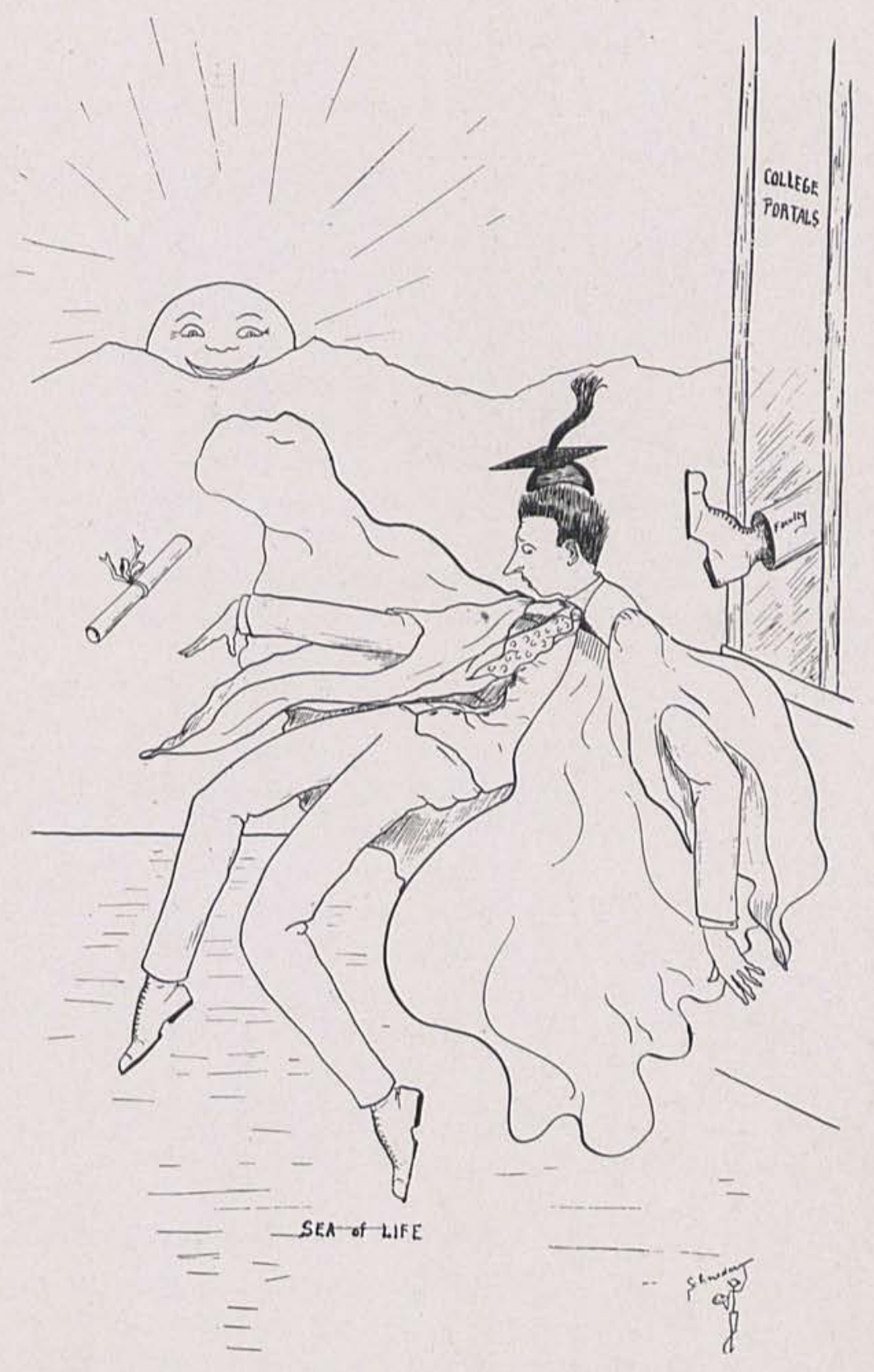




\section{9}

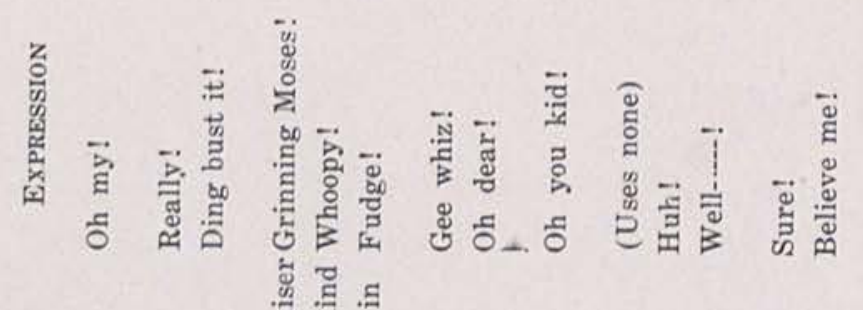

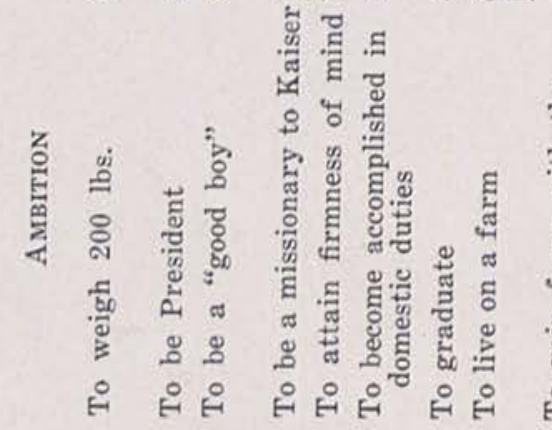

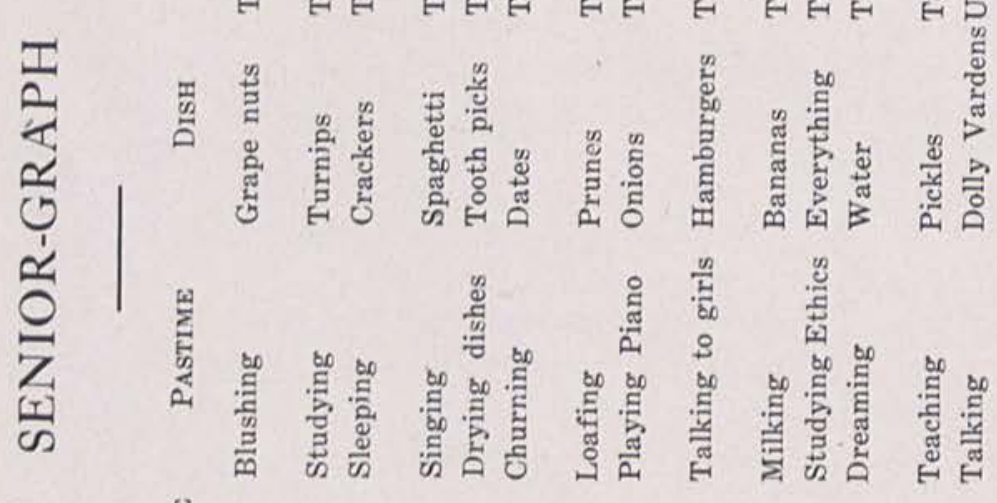

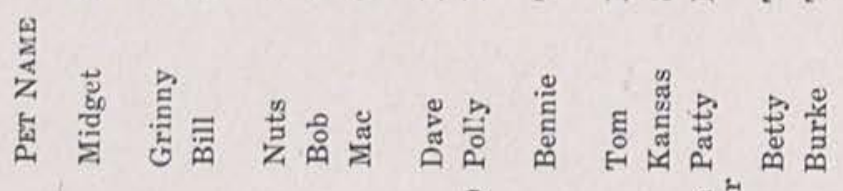

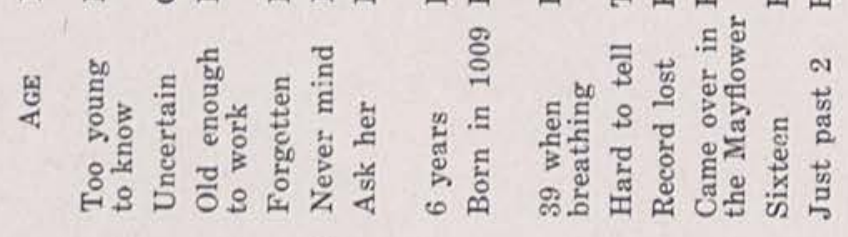

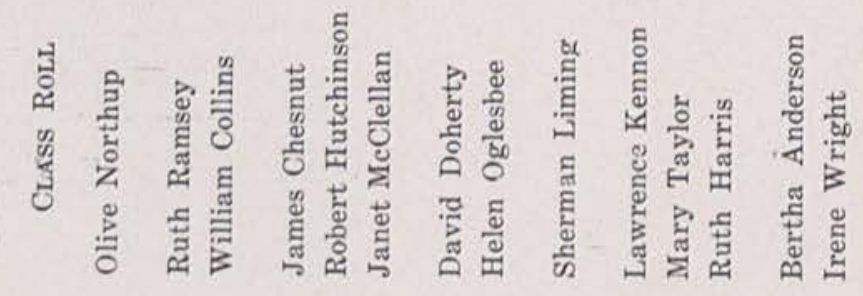




\section{RETROSPECTION}

I was sitting alone by my fireside

One evening a few days ago,

While the light of the dying embers

Lit the room with their flickering glow.

You wouldn't know me now, I'm sure-

Dear classmates of long ago,

For the hair that was black as a raven

Is now as white as snow.

Many years have passed since I saw you-

Years of both gladness and strife;

But there's one endearing memory,

My friendships in youth's gay life.

And in reverie I pondered

On my college days long past

And in fancy lived them o'er again

From the start e'en to the last.

First, when we were Freshmen-

How clearly do I remember!

We were entering a new life highway

On that day in bright September.

Oh! the jolly times we had that year!

Our teachers frowned in wonder-

But we were happy - care-free, then-

And did not mind a blunder.

It was when Sophs we made our fame;

'Twas on dear old Cedar Day.

We captured the horrible Villa

And thousands watched the fray!

As Juniors - of course we were sensible;

Learned to study and concentrate.

No longer the professors glared at us 


\section{9}

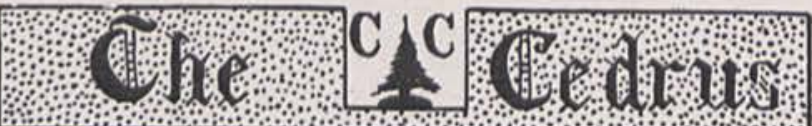

\section{RETROSPECTION -- Continued}

Even if for class we were late (?)

How quickly those days did pass by ;

Days of gladness and blissful joy,

With our spreads and college parties

And no problems to annoy.

Our Senior year was the brightest

And yet the saddest, too.

For we realized that our college days

Were vanishing-almost thru.

And at last when came the parting,

Our hearts were as heavy as lead;

Yet eager to search the future

And find what lay ahead!

Oh, classmates, as I ponder

On those college days so dear,

I feel no longer lonely,

For each smiling face seems near.

Yes, years have passed since I saw you,

But as onward in life I go

The picture will ever be with me,

Dear classmates of long ago.

So I dream, dear ones, about you,

By my fireside all alone.

Without the rain is falling,

And the weird winds wail and moan.

On the hearth the last coal flickers

And the shadows nearer seem,

But the glow in my heart remaineth

For the dear old class ' 18.

N. I. W. 


\section{9

William Rife Collins, A. B. Cedarville, Ohio

"Oh, it is excellent to have a giant's strength."

Helen Pauline Oglesbee, A. B.

Cedarville, Ohio

"Never idle a minute, always busy."

NAOMI IRENE WRIGHT

Cedarville, Ohio

"What sweet delight a quiet life affords."

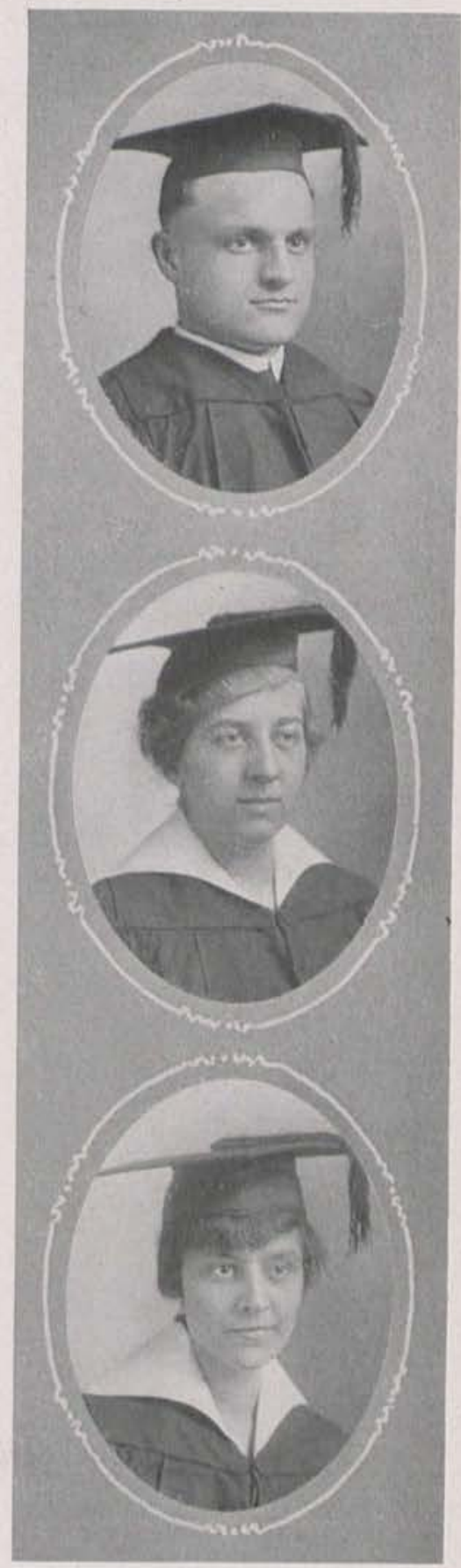




\section{9}

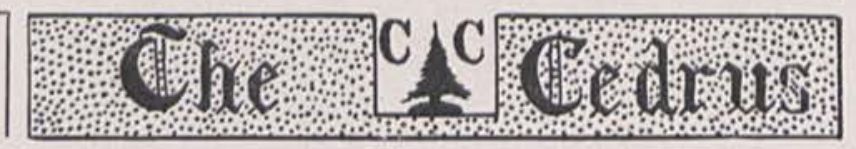

\section{8}

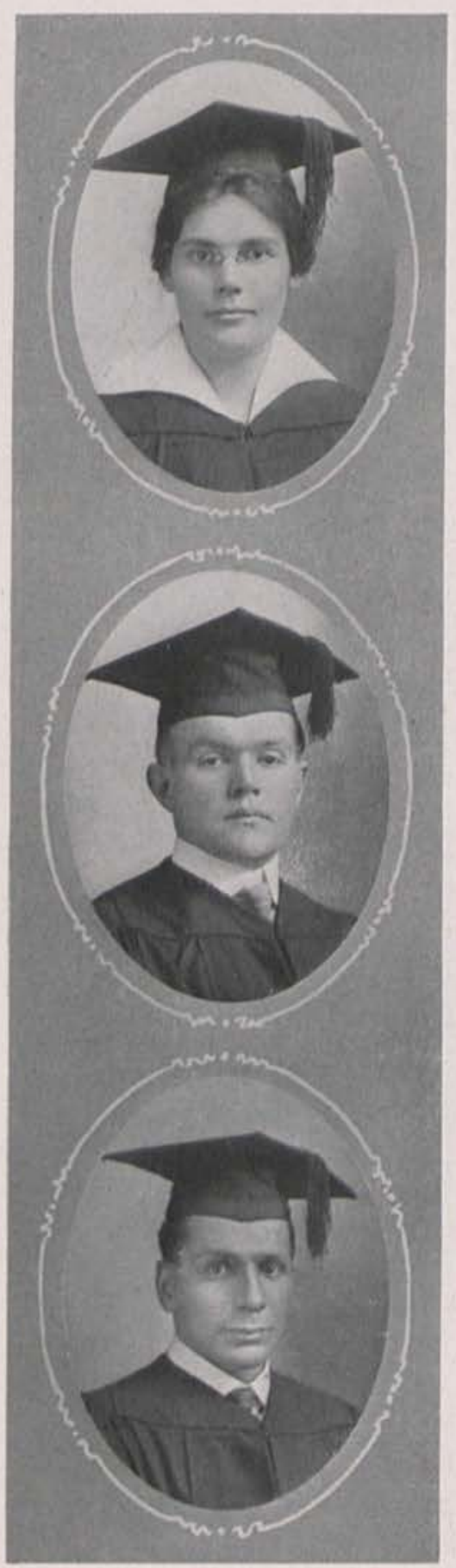

JANET ELIZA MCCLELLAN

Xenia, Ohio

"Here's to the girl with a heart, who makes this bubble of life worth while."

\section{JAMES LyONS CHESNUT}

Cedarville, Ohio

"And unextinguishable laughter shakes the skies."

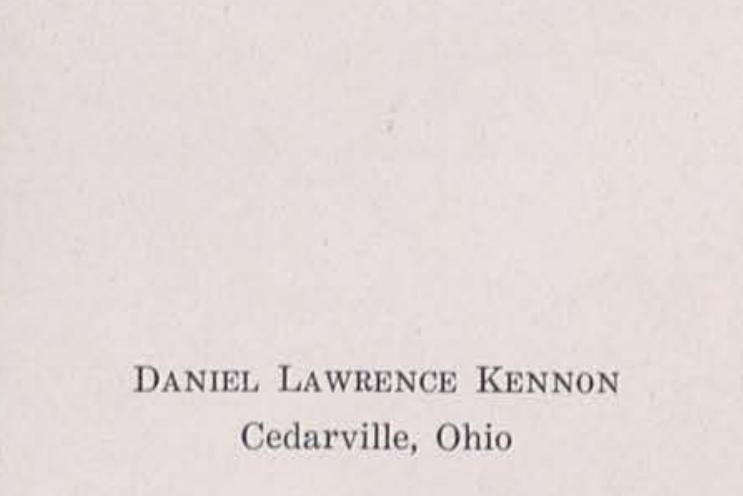

"He is winding up the watch of his wit; and by and by it will strike." 


\section{9}

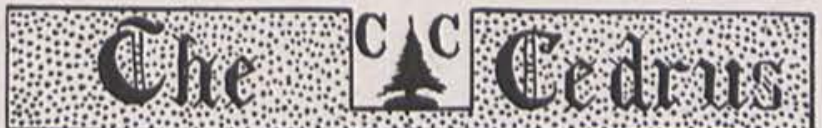

Carrie Olive Northup Clifton, Ohio

"Little strokes fell great oaks."

SHERMAN OMO LIMING

Hamersville, Ohio

"He has a lean and hungry look."

ROBERT LINTON HUTCHINSON Cedarville, Ohio

"Whatever anybody does or says, it must be good."

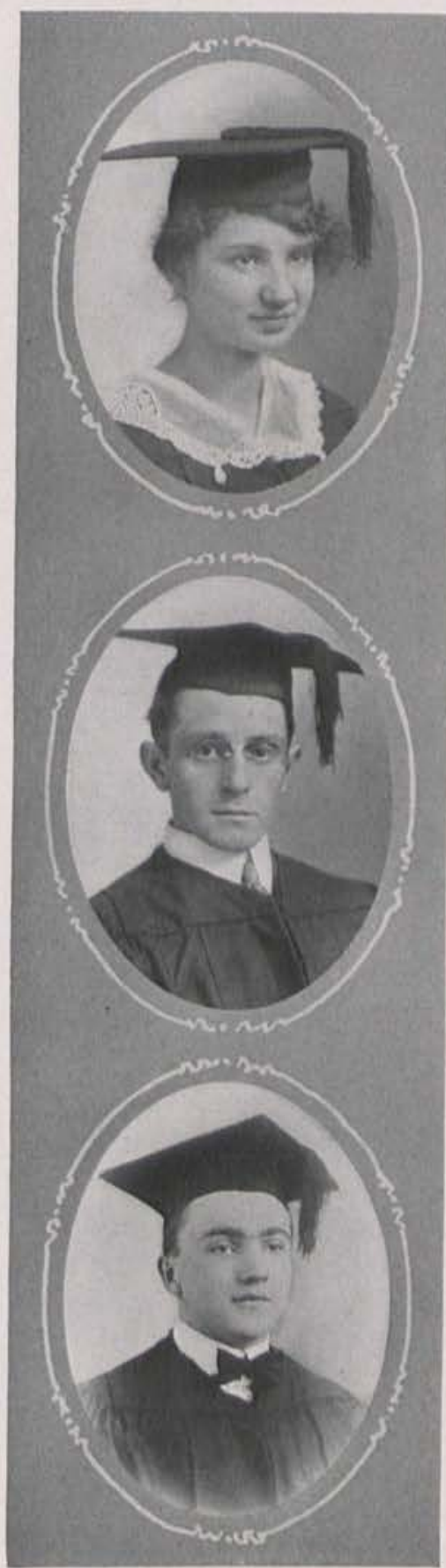



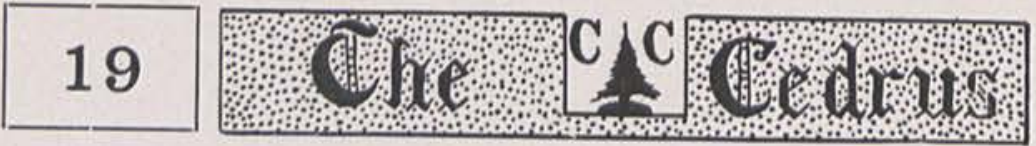

\title{
18
}

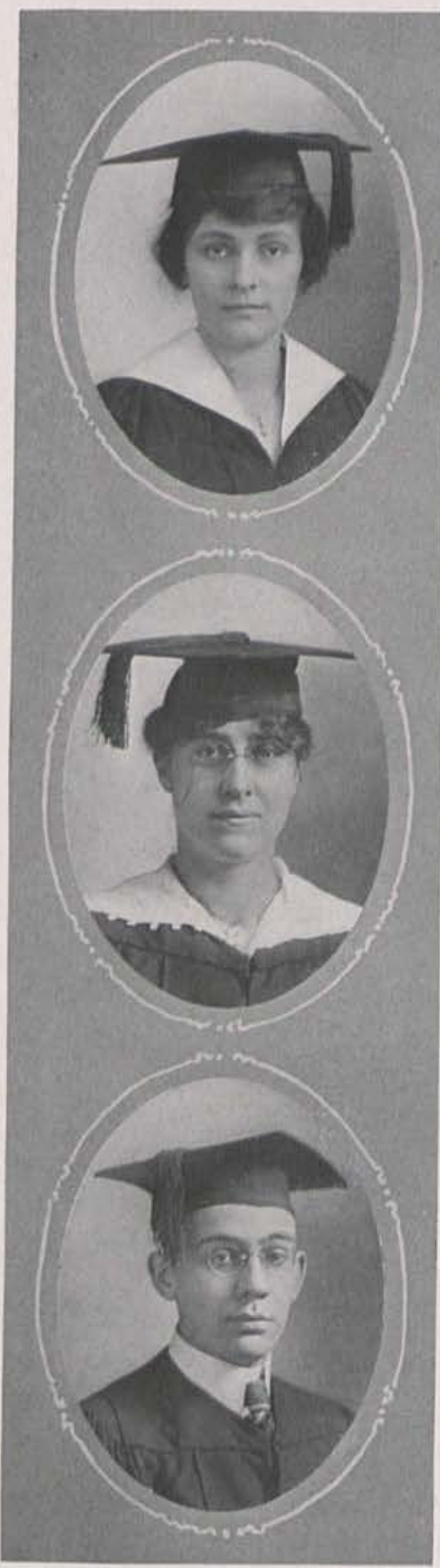

\author{
RUTH ROSETTA HaRRis \\ Dayton, Ohio
}

"And you love to feel her clinging like the blossom to the bough."

\section{MARY TAYLOR}

Manhattan, Kan.

\section{"Mary, maiden fair,}

Such should, methinks, its music be;

The sweetest name that mortals bear."

\section{DAVID LINTON DOHERTY}

Philadelphia, Penn.

"Don't do today what you can put off till tomorrow." 


\section{9}

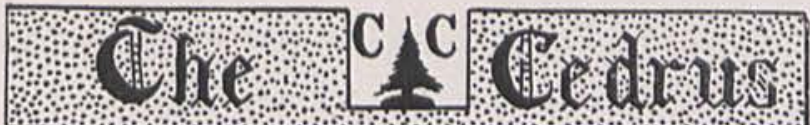

MRS. LEROY ALLEN

Cedarville, Ohio

"She has as many virtues as there are spokes to a wheel."

BERTHA ANDERSON

Cedarville, Ohio

"Of mystic beauty, dreamy grace, And ever with smiling face."

Mrs. ROBERT HUTCHINSON Cedarville, Ohio

"Her kindness and her worth to spy, You need but gaze on Myrtle's eye."

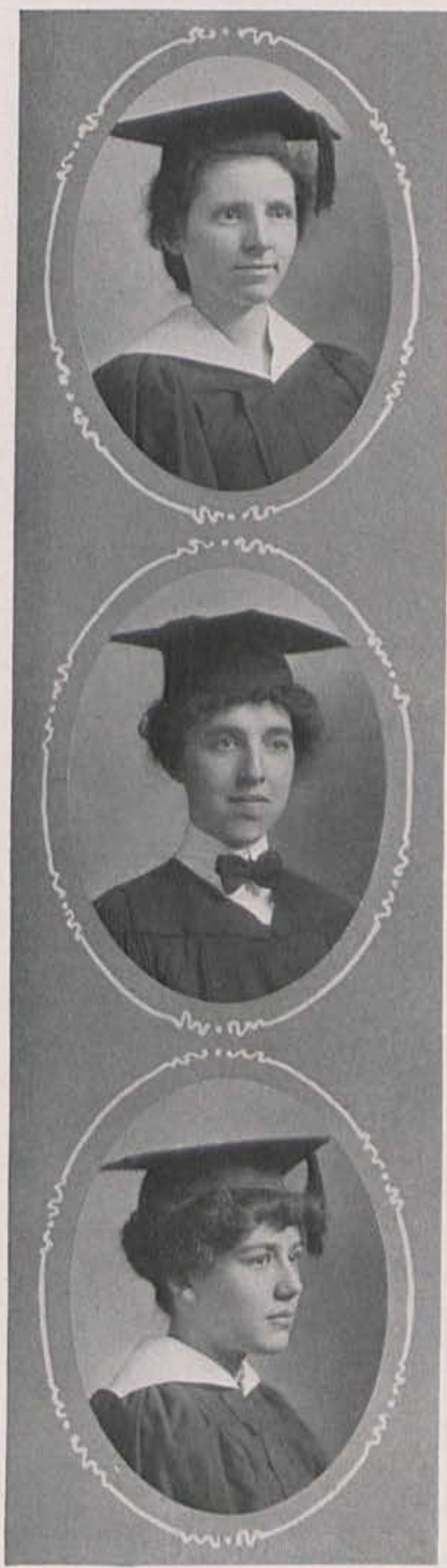




$$
\text { แUMIRS }
$$

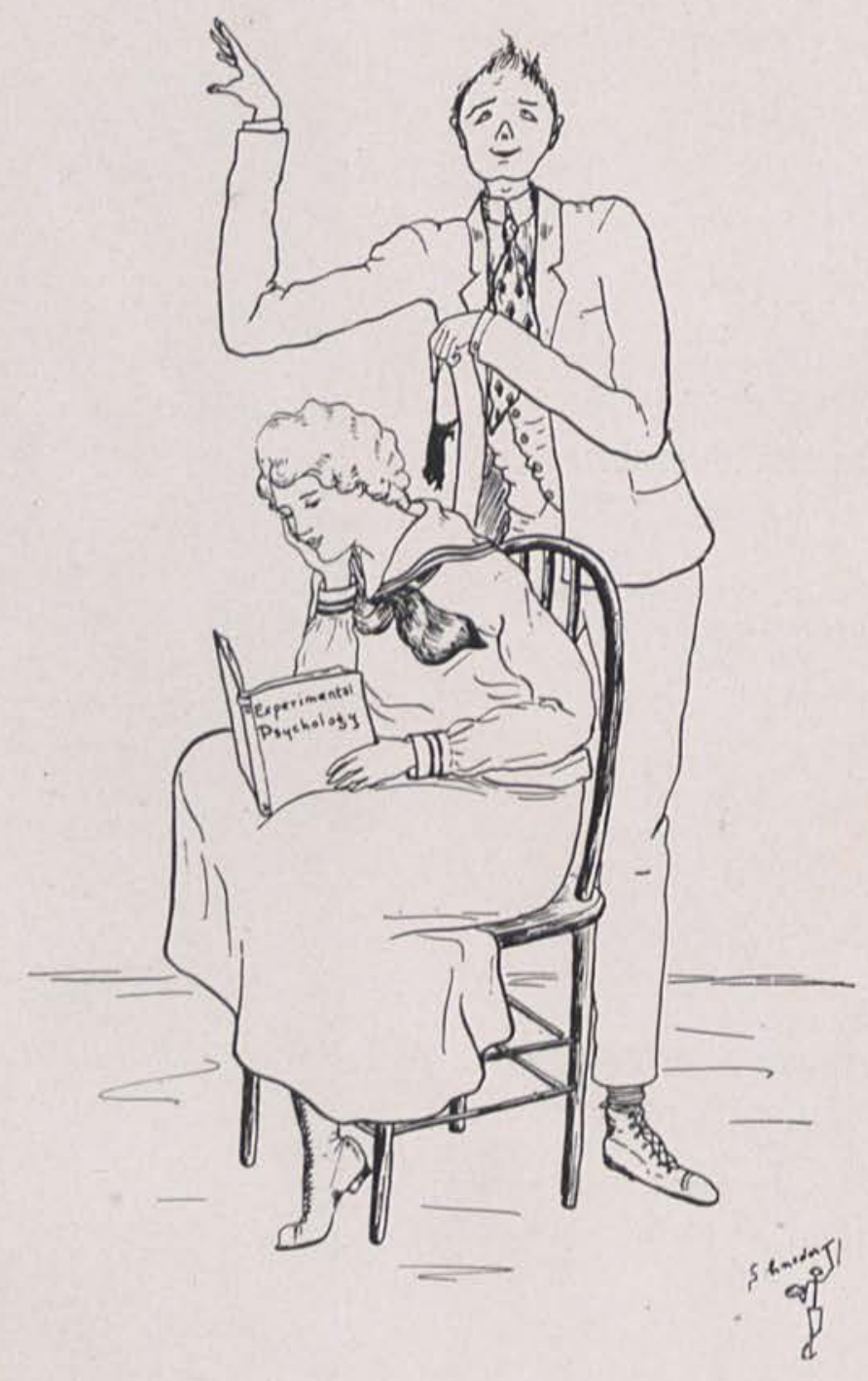




\section{9}

\section{JUNIOR HISTORY}

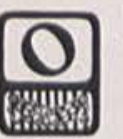

N September 14, 1915, we, twenty-three merry lads and lassies, entered Cedarville College. Our ambitions were high and our motto was "Hitch your wagon to a star." Time is too short to relate the events of that year. Although June came all too quickly, we said "good-bye" with hopes of meeting again. But,

\section{"The best laid plans of mice and men}

Gang aft aglee."

September, 1916, brought back only thirteen of our original twentythree. However, two strangers joined us that year. Spreads were less numerous than in the previous year. But we were not yet so dignified that we didn't chase the Freshies home from prayer meeting.

Our Junior year has been a pleasant one. We have at least begun to apply ourselves seriously to our books (though perhaps not from choice). We shall now try to set forth some of the merits of our class. Oliver Cornwell-tall, slender, good-natured "Ollie" is the star basket-ball center. "We just can't play without Ollie," so say the rest of the team. Helen Creswell is our country girl, who does her share for her country by knitting, and is always ready for a spread. Bob Colman, our friendly pastor, often selects this text,

"Woman, the morning star of infancy,

The day star of manhood,

The evening star of old age.

Bless our stars.

But may they ever be kept at a telescopic distance."

To our class the Faculty turned for an assistant in Chemistry Laboratory, and chose Allen Turnbull, who so well filled the position last year.

William Anderson displays great business ability. For two years he served as Assistant Business Manager for THE CEDRUS, and he is also President of our class.

Olive Finney is a quiet, reliable girl (Treasurer of the Y. W. C. A.)

Meryl Stormont is a patriotic Junior doing his part to feed the allied armies.

Louisa Finney is another country girl who cuts classes only when the snow is deep.

Some people wonder if Norman Foster is as happy as he looks. We can testify his good nature is permanent. His smile won't rub off.

George Smith was the College orator. However, he is now engaged in patriotic service on the farm.

Of the writer of this letter the "least said is soonest mended."

JUNIOR HISTORIAN. 

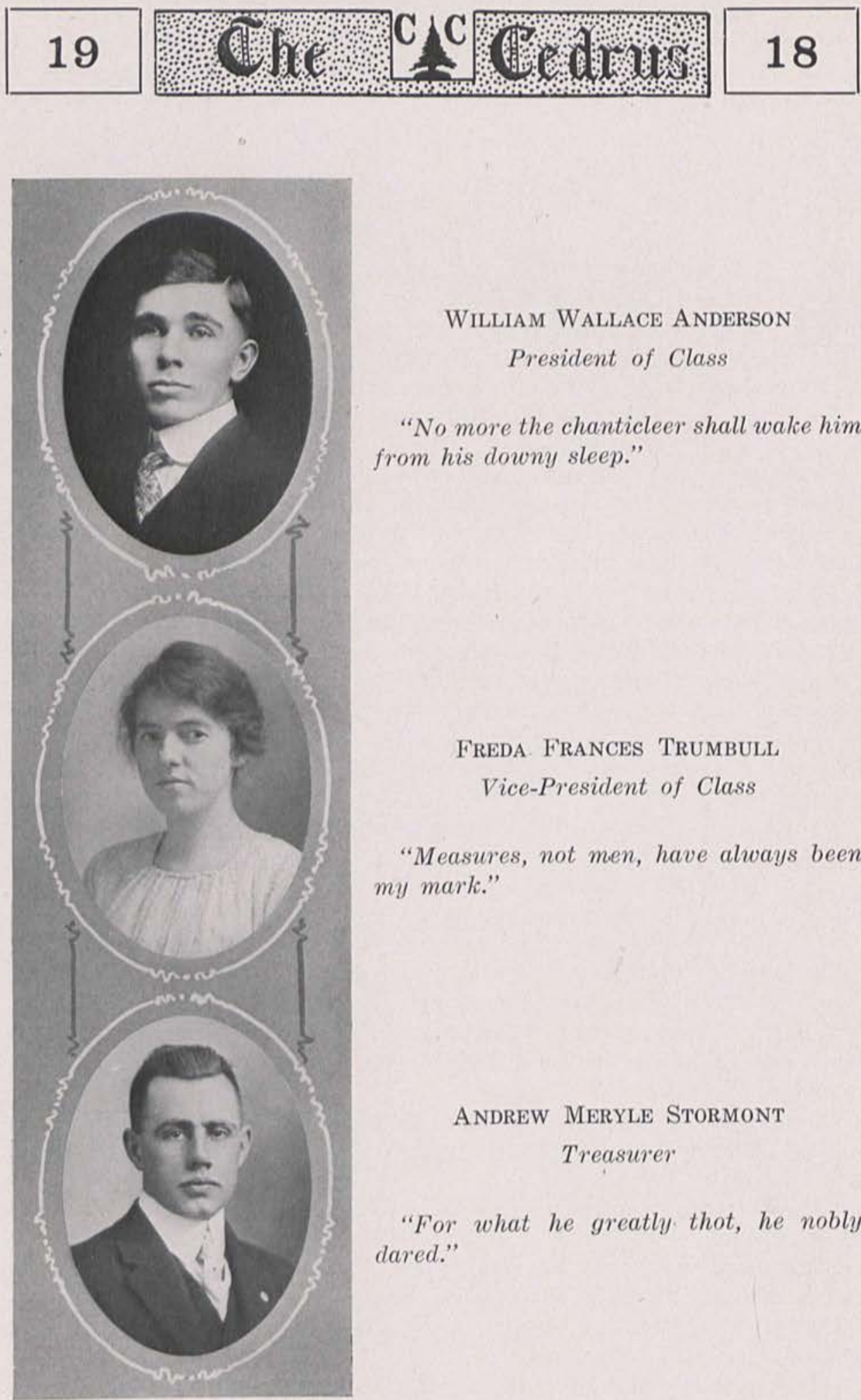

William Wallace Anderson

President of Class

"No more the chanticleer shall wake him from his downy sleep."

Freda Frances Trumbull

Vice-President of Class

"Measures, not men, have always been my mark."

\section{ANDREW MERYLE StORMONT \\ Treasurer}

"For what he greatly. thot, he nobly dared." 


\section{9}

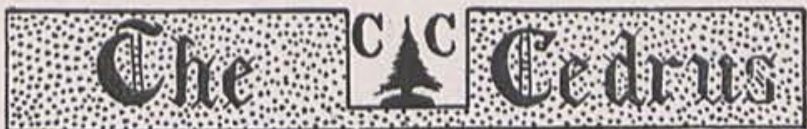

RoBert Nichol COLMAN

"My only books were woman's looks, And folly's all they've taught me."

Margaret Ellen Elder Secretary

"A loving heart is the beginning of all knowledge."

NORMAN BAIRD FOSTER

"When woman's in the case, all other things give place."

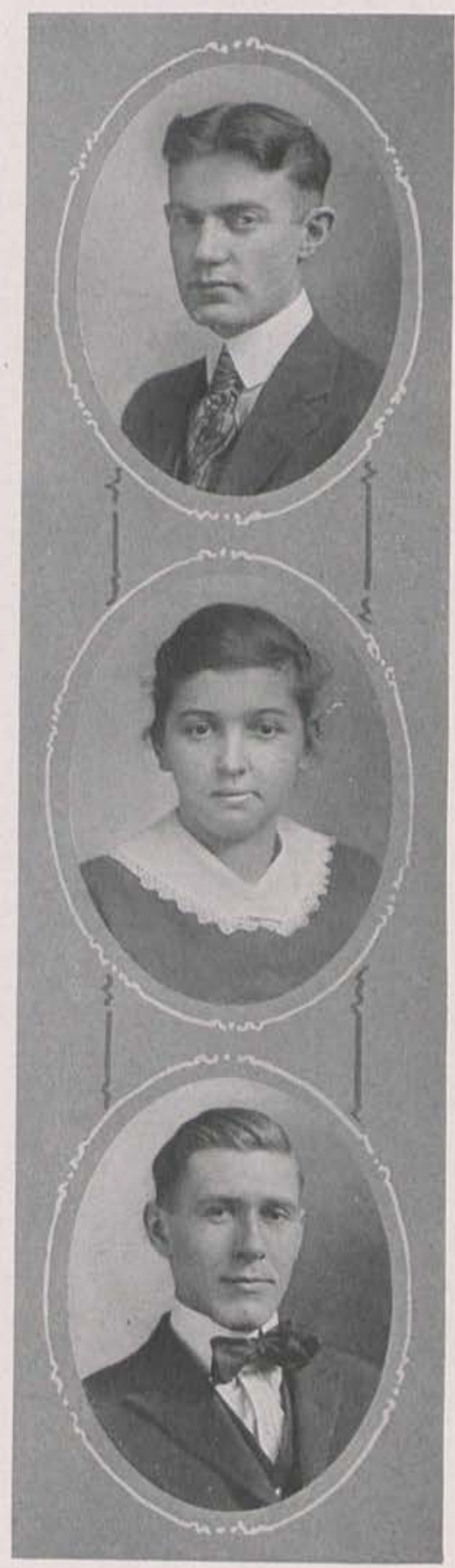




\title{
19
}

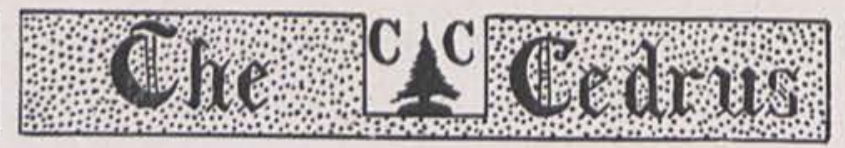

\section{8}

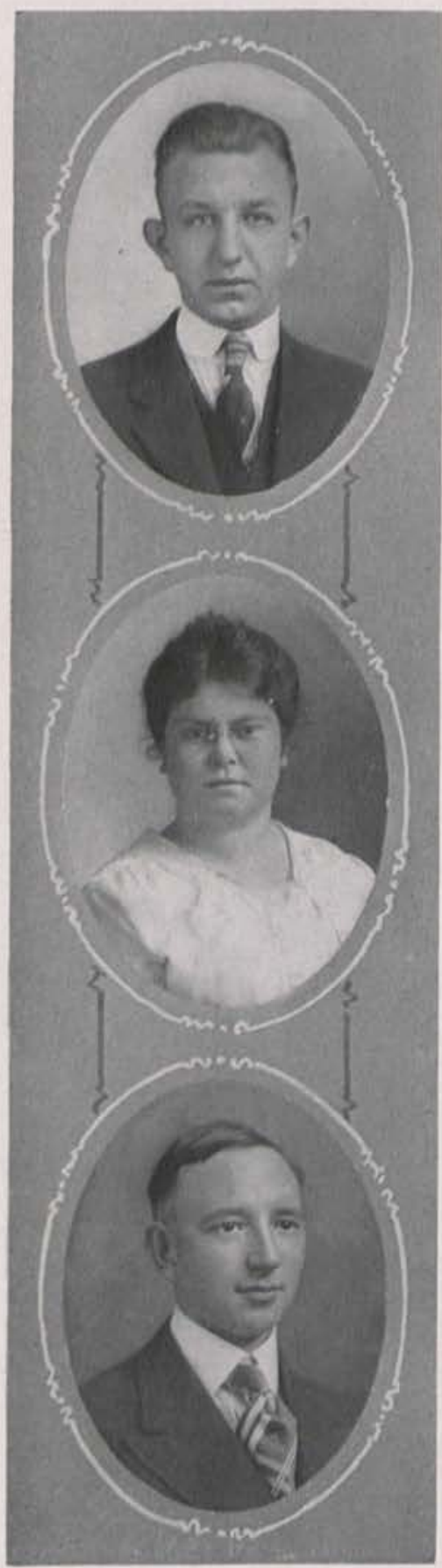

\author{
OLIVER Kelly CORNWELL \\ "Divinely tall, and most divinely fair."
}

Helen Creswell

"Her sunny locks hang on her temples like a golden fleece."

Allen Blue-Bird Turnbull

"Whence is thy learning?

Hath thy toil o'er books

Consumed the midnight oil?" 


\section{9}

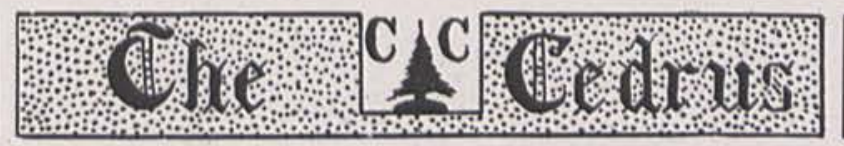

18

Olive Eunice Finney

"And the best of all ways

To lengthen our days

Is to steal a few hours from the night, my dear."

Walter Chang Tong Chu

"Better fifty years of Europe than a cycle of Cathay."

Margaret Louisa FinNey

"My heart is true as steel."
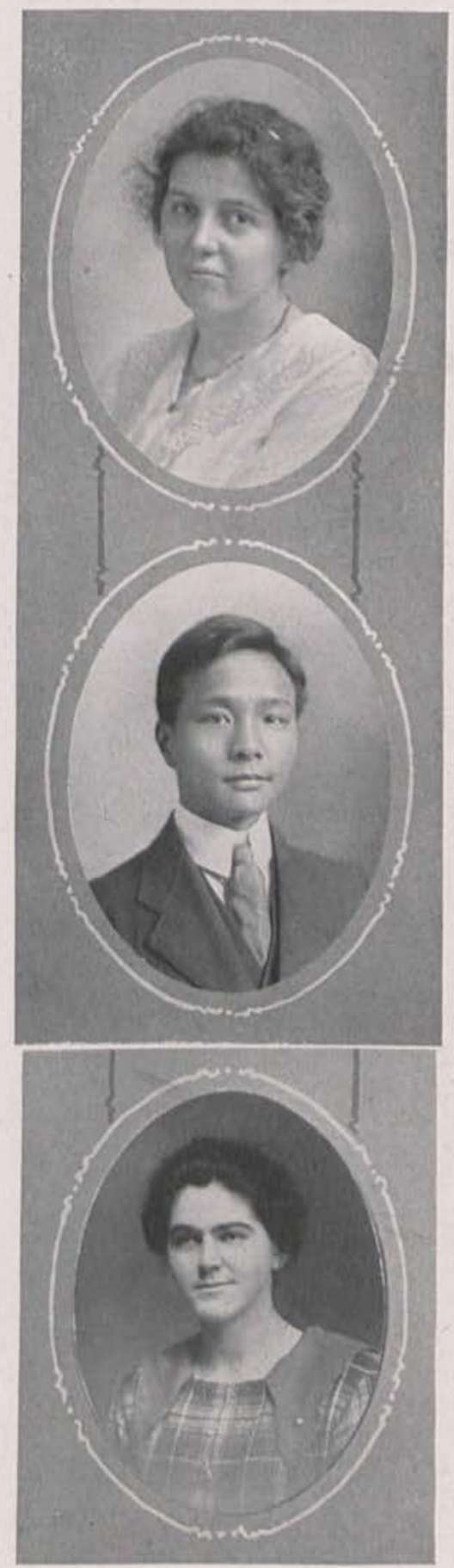


\section{9}

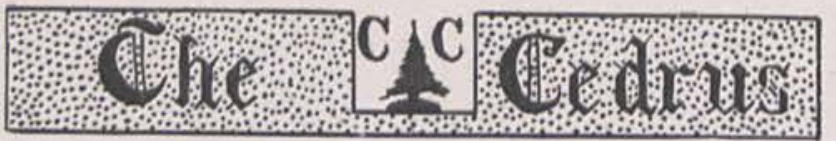

18

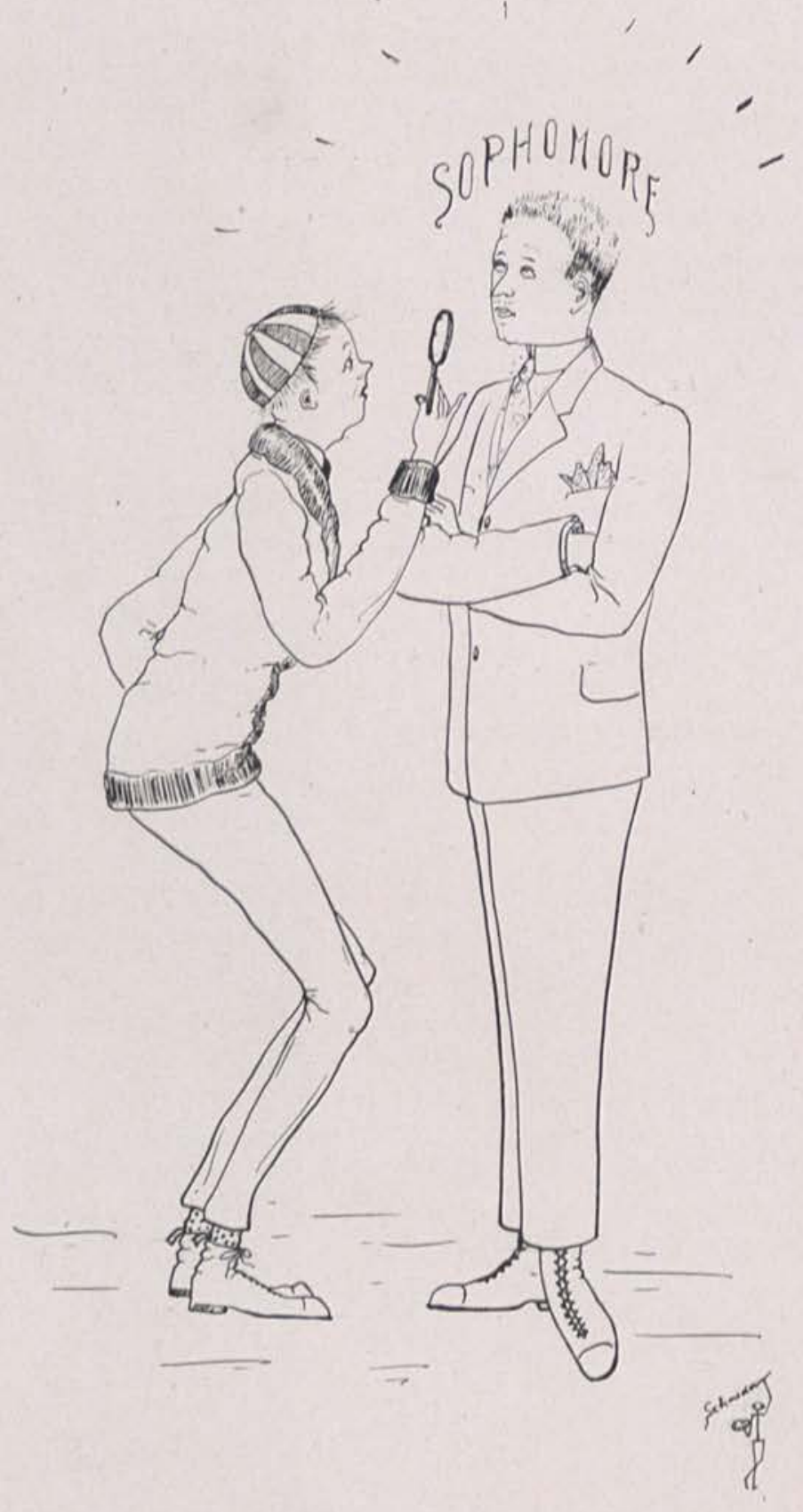




\section{9}

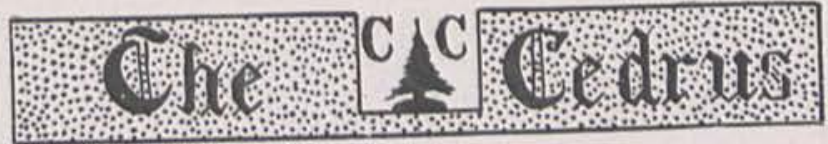

\section{ASTROLOGY OF THE SOPHOMORE CLASS}

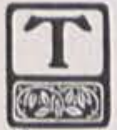

HE subject for discussion is: "Are the Sopho-more or less?" As an introduction we would suggest to the uninformed and forgetful that they read in last year's CEDRUs the truthful statement as to the personnel and morals of the then Freshmen class. We are still an organization of geniuses. We have not changed in the least. We respect ourselves as much as last year and we have as much nerve as ever, (a few of us hate to get up on cold mornings, however).

A few of our classmates could not return, much to our regret-and theirs. Several students, after entering Cedarville this year, decided to become Sophomores. Our class is as large as ever and we are glad to say, the largest of the classes. We are sorry we cannot pat ourselves on the back because of that. We acknowledge our debt to society-and the grades the professors lend us. A few of the members of our faculty actually give grades, but we cannot mention names. To do this would be illogical and unethical.

The next point in discussion is beyond refutation. We are a class of stars. You may recall the assertion that there are twelve magnitudes of stars. Forget it. We are not talking about that. Each Sophomore is a different magnitude for that matter, so we are more distinctive and varied than the stars. Our thought is that we shine (like stars), have numerous good points (stars have five, it is said), and are out only when the weather is good and the sky is clear and there is something worth seeing on the earth, (the best time to see the stars).

The most enjoyable time for us as Sophs was when we had a roast and spread at the Cliffs. The whole crowd climbed down the rocks over the reptiles and dead whales (relics of the Flood), to the camp, where we stood around the fire waiting until we had to sit down. Then we told lies until we had to stand up for the truth. The stars went in so we started for home. Unfortunately for a flock of pigs and hogs, we happened upon them while they were snoring peacefully, resting after the day's plowing. Several of the girls began calling the sausages, believing them to be acquaintances (we supposed). Being thus rudely awakened from slumber the pigs squealed and the hogs swore, until a dog began to bark-until a school of cattle commenced shouting for breakfast. It was a most exciting occurrence. The sad part of the affair was the manner in which the cows gazed reproachfully at us as we edged by. The Cliff is a grand site for a picnic and we are going to have more there when the stars stay up later.

Most pleasant was our planning of sled rides over the crystal roads and of spreads in town and out of town. Most tasty, wholesome and comical were the viands we imagined. It matters not that some did not materialize. "As one thinketh so is he." A spread planned is a spread in hand.

We had a "Hoover Banquet" also, which is a class secret. Other things which we have done or expected to do, we consider it the part of diplomacy to keep safe in our archives. We like the other classes in certain places, but not in our place. The future may tell, but Sophs-never.

We conclude with an exhortation to the old to remember that the stars are in their places ever, seen or unseen, and to the young - to be hopeful. You may be Sophomores some day. P. J. E. 


\section{9}

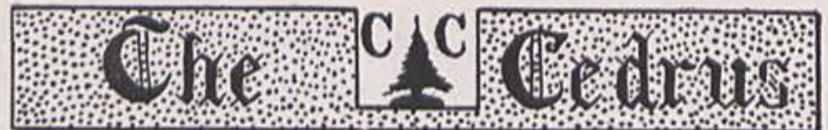

\section{CLASS POEM}

The Sophomore Class of Cedarville College

Is lively and jolly, yet crammed full of knowledge.

With spreads, hikes and parties they have lots of fun,

And yet in the class-room their work is well done.

They're an all-star class, clever, witty and bright,

(Now, if you're from Missouri they'll show you all right)

And if even then you're inclined to doubt,

Just speak to the Profs. and you will find out,

That this wonderful class whose praises are told

Cannot be valued in silver or gold.

Now, take Millie, for instance, she's bright as new dollars,

In fact, Roger dares not wear celluloid collars.

There are Reba and Helen-in grades they excel,

While Dean and Duncan do equally well.

As for music-Rebecea and Maud play and sing,

Till worry flies on "the dove of a wing."

There are some who are jolly good comrades for all,

For example take Clark, or Mildred, or Paul.

And then there's our Dorothy, a sweet little lass,

Who usually stands near the head of our class.

As for Rickenbach-he is as bright as can be,

'Tis true! Why, he is one of the Faculty!

Then there's Ellen-she's favored by every one here;

At least Morton declares that she has not a peer.

But only one thing they lack-and ah, how well they know it,

This most excellent class contains not a poet!

'Tis sad, but true - not a myth or a story,

Thru their acts-not their words-must you look on their glory,

And when in the future these lines you scan,

Just try to remember then, if you can,

That Class ' 20 had both more fun and more knowledge,

Than any that e'er trod the halls of this College.

M. M. G. 


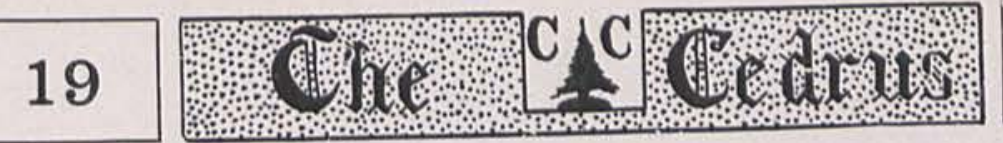

18

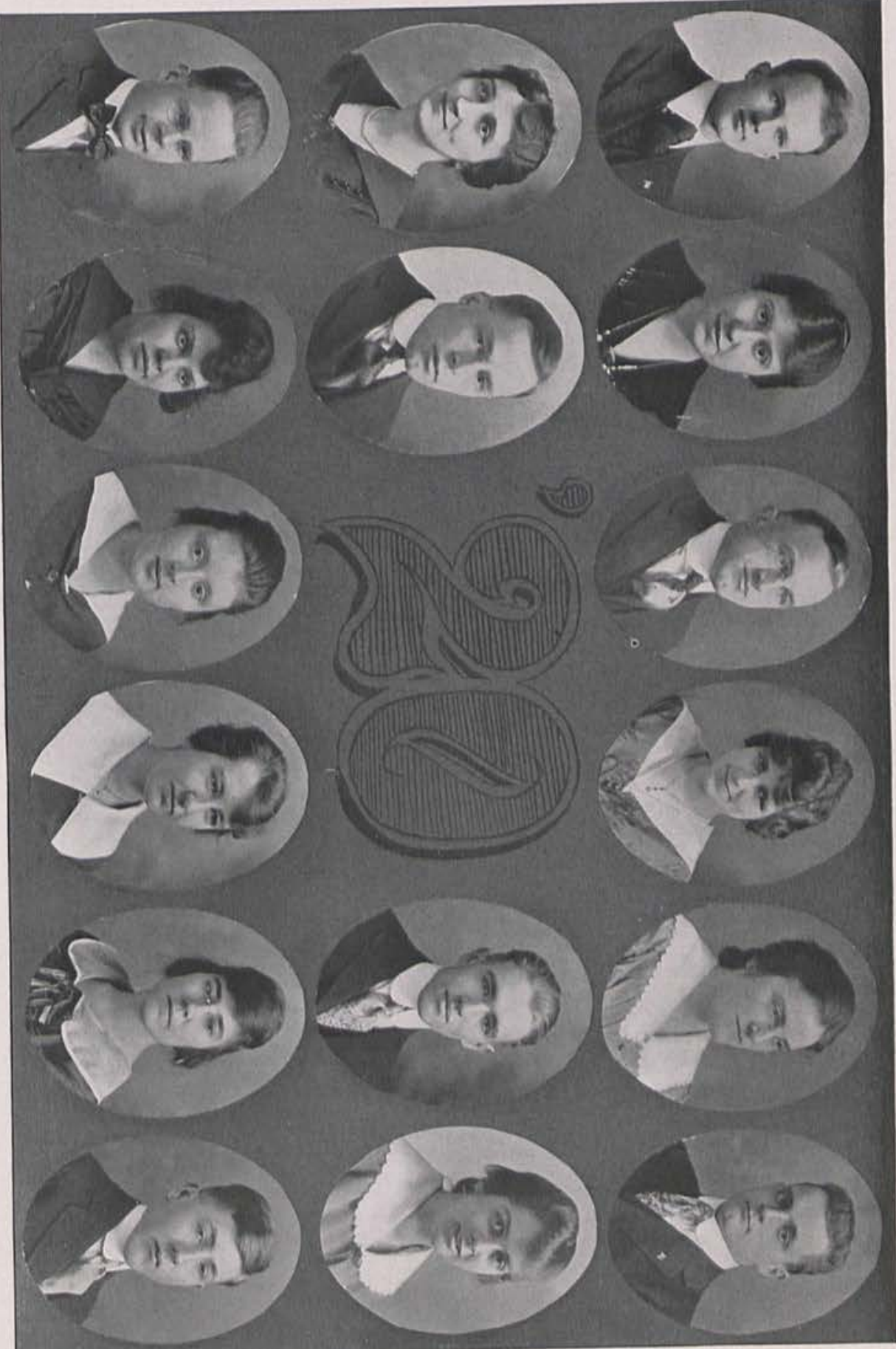



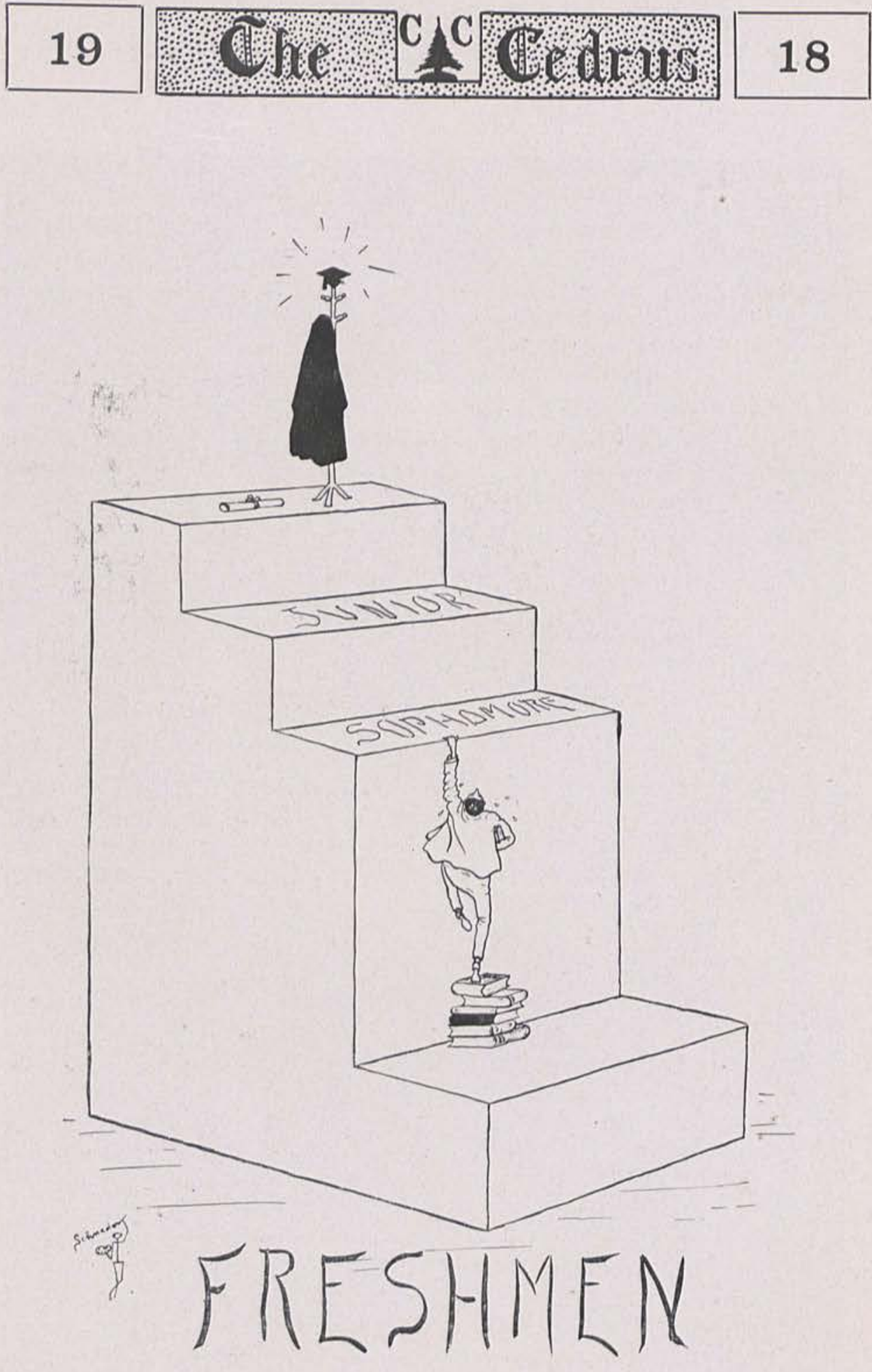


\section{9}

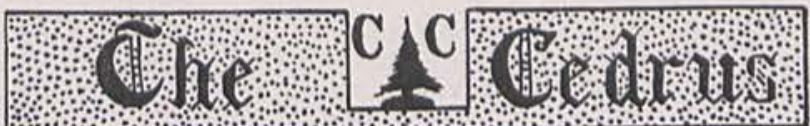

\section{FRESHMAN CLASS HISTORY}

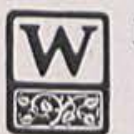

HEN Cedarville College opened her doors of learning in the fall of 1917 , twelve fine and promising young men and maidens registered as Freshmen. To be sure, we were these Freshies, and, of course, we were sniffed at for a few days, but we soon learned the ways of College life, and now we are the pets of our Professors and the praise of the students. Of course we do not mean to be proud or to be afflicted with megalomania, (excuse the big word). However, we are proud of the fact that we have a student from the largest city in the land, Nelson Thorn, a real New Yorker. He is a member of the first basket-ball team, and plays a great game. Our President, Robert Edwards, is from Clifton, a small city out near "No Man's Land." His ability as an executive is well worth mentioning. Harry Wright, the genius of the Science Department, discovered just recently that there were only two germs in kissing-namely, marriage and divorce. (Beware! Beware!)

What did you say? The girls? Oh, sure, we must not forget the girls. We have tall girls and short girls, heavy-set girls and slim girls; girls who are pretty and those who are beautiful; those whose hair is curly and those who cannot curl it. There is Zelpha Dobbins, the girl with a determination to make her mark in the world. Ida Rees, Uncle Sam's patriotic cook, who has shown her ability in working out the Hooverized meals at the Club. Nothing needs to be said about one of our members, just ask "Bob." Hannah Isaac, our Pennsylvania girl, failed to return after vacation. We understand that she has changed her name. Oh, well! another soldier was made happy.

Grace Bradford also left our class a short time before the holidays. Then there are Helen Stewart, Lois Burns, and Elizabeth Dean, all expecting to be teachers. Ohio will have reason to feel proud when such girls as these go out into her schools.

It is beyond the power of any historian to describe our social functions. You would really have to attend them in order to know the real good times that we have together. We are famed for our spreads and our knack of getting away with them.

Yes, friendships have been formed which we can never forget, and many faces have become endeared to us.

If the following words of the historian were prophetic, they would be after this manner: I see the class of 1921 graduating from the halls of Cedarville College. In it are included doctors, ministers, professors, scientists and teachers who are just about to assume their places in the world, fighting the good fight in the Battle of Life.

D. H. H. 


\section{THE FRESHMAN CLASS}

Do you remember the Freshman Class

That started in '17?

A jolly bunch and lucky, too,

Though our number was just 12 .

Our class was small, indeed, 'tis true,

Yet high ideals we held in view.

We were varied in height and weight and looks,

And shy at the sight of our new text-books,

When first we met that September day

And as Freshmen started our College way.

Now in starting, of course-I tell you what-

There is always somewhere a hardest spot,

In History, Latin, in Math., or in English,

In Psych., or in Science, in Lab., or in Spanish,

In every course there is hidden still,

Find it somewhere you must and will-

Above or below, within or without-

And that's the reason beyond a doubt,

The Freshmen must work or they have to get out.

Do I tell you, I rather guess,

This class was a wonder and nothing less!

We worked real hard endeavoring to show

The many professors that we're not slow

In gaining the knowledge that they know.

Now, Eva said, (as teachers do,-

With a "Listen here," or an "I tell you").

"It's here I started to learn the rules

How I can well improve the schools."

One of these girls I will tell you fair

Was Ida Rees, with her flowing hair.

She studied hard for a week or two

And decided then t'was too much to do

To make the credit of 22 .

Helen and Zelpha and Robert and Thorn

All came to school in the early morn.

Each was trying his course to fill

While the parents were having to pay the bill.

Harry Wright on our roll does appear,

While Grace was with us but half a year.

Lois, Eliz'beth, and Hammond, all three

In our Freshmen Class are glad to be.

Hannah Isaac stayed a little while

But at New Year's bade us adieu with a smile.

You see, of course, if you're not a dunce,

How Soph'mores we became at once.

Our Freshmen year we had journeyed thru;

Next year we'll be ready more work to do.

This story I've told you is both sad and gay,

For our college days soon pass away.

(With apologies to Holmes).

Z. M. D. 

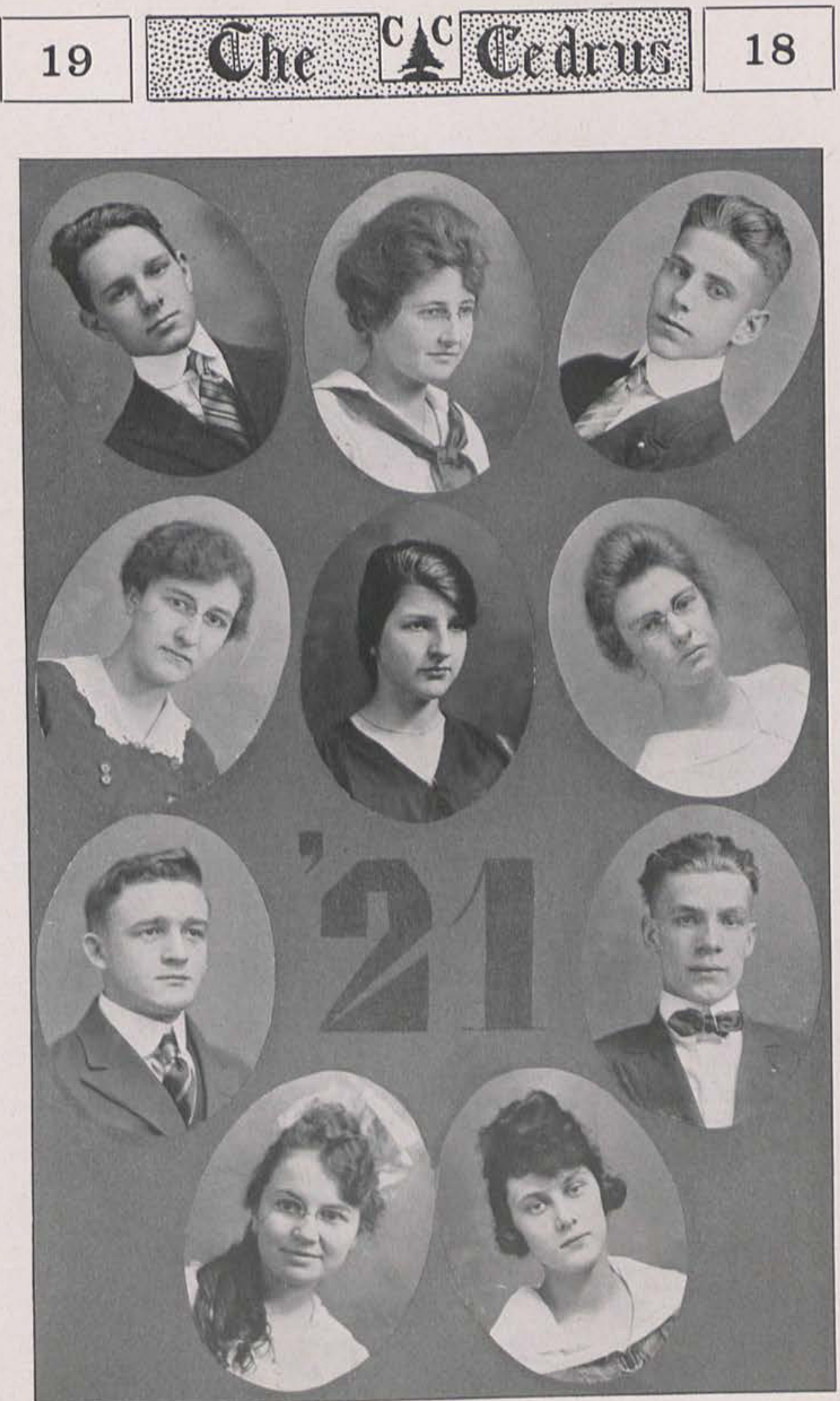


\section{CEDAR DAY}

EDAR DAY, May 10, 1917, dawned bright and clear, with just a hint of rain in the soft, spring air. This was the day for which the students had been so faithfully practicing in every spare of our capable little English teacher, Prof. Margaret Schneder.

The large crowd was on the tip-toe of expectation as they gathered around the large circle in which the stunts and May dances were to be given.

First on the program were the stunts given by the four college classes. The Freshmen class entered the ring behind four of their number, who bore upon a stretcher the body of a classmate, who, weakened physically and mentally by the frequent severe quizzes, had succumbed to the fumes of the chemistry laboratory. With appropriate wailings, his body was carried to its last resting place, where it was properly taken charge of by inhabitants of the lower world.

Next the Sophomores gave a stunt which typified the attitude of President Wilson and Theodore Roosevelt toward the present war. As these two men were discussing the advisability of Roosevelt taking an army to Europe, a German submarine entered the ring and torpedoed the "Ship of State." Roosevelt immediately called for a volunteer army, which instantly responded, uniformed and armed for service.

The Junior stunt outlined the war with all the European countries represented. Belgium and Serbia were ruthlessly overrun. The Stars and Stripes finally entered the conflict and the tide of war immediately changed in favor of the Allies. The Kaiser was killed and Columbia in triumph stretched her protecting arms over the war-worn allies.

The Senior stunt represented the Kaiser trying to escape from Germany in a submarine. His boat was found and torpedoed by a larger United States vessel. As his Imperial Majesty sank beneath the waves, bleachclad inhabitants of Davy Jones' locker kindled a fire with which to greet the soul of His Eminence as their red-robed imps brought him in. The scene ended with "Kaiser B" trying to escape from the torturing prongs of his captors.

Following the stunts came the May-day exercises. The procession started from the south entrance of the main College building, proceeded to the main entrance of the campus, from there across to the tennis court, thence down to the ring.

First in the procession were the heralds, Professors Wright and Parker, dressed in appropriate red costumes with white, ruffled collars, and carrying long trumpets with which they announced the coming of the Queen. Following the heralds was the dainty little flower girl, Miss Olive Northup, and behind her, the crown-bearer, James Stormont, carrying the crown on a large satin pillow. He preceded the former May Queen, Miss Dorothy Collins, who was to crown Miss Ruth Ramsay as Queen of the May. Next in the procession came the flower-bedecked coach drawn tandem-fashion by two gallant ponies, astride of which were white-clad pages. Following 


\section{9}

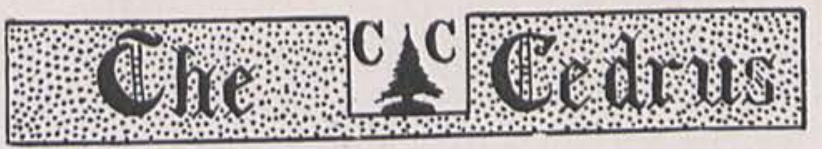

\section{8}

\section{CEDAR DAY -. Continued}

the coach were the lovely ladies in waiting, each accompanied by her chivalrous, plumed knight.

Next in order were the Foresters clad in dark greens and browns, followed by the sturdy Highland lads and lassies in their Scotch kilts. Behind these capered little white sheep, herded by the brave shepherds and winsome shepherdesses. The comical jesters in long-eared caps and belltrimmed suits came next, just ahead of light-footed fairies who were dressed in costumes of rainbow hues. Last but not least in the procession were hobby-horses who made fun for every one. When the procession had passed around the ring to the Queen's throne, the courtiers helped the lovely, dark-haired Queen to alight, and she was then crowned, while all of her followers remained on bended knees. After the queen had ascended to her throne, the dances were given. First the stately minuet, by the ladies in waiting and the courtiers, and next the dance of the shepherds and the shepherdesses, in which they drove the little lambs home; next the Highland Fling, which was performed in a manner very creditable to the participants. The fairy dance was a maze of bright colors, gauzy wings and flying curls. The fairy solo-danee given by Miss Schneder was a very beautiful and difficult one and showed that its author is an accomplished artist. The merry jesters deserve a great deal of credit for their performance, which ended the program.

Immediately after the exercises the guests were taken to the gymnasium where they were all seated at long tables. Before this account was written orders were sent all over the country to make use of the war menus just published, and as it was no war menu which was served that day by the ladies of the community, it will be better not to describe it. After dinner the usual custom of speech-making by distinguished guests was followed.

Then every one assembled on the College campus while the beautiful flag presented to the College by Dr. M. I. Marsh was raised, and Dr. McChesney, in an appropriate address of acceptance, thanked the donor, who responded very graciously. As the flag floated out over the assembly below, the students united in singing the "Star Spangled Banner" and the "Marseillaise."

Following the flag-raising the crowd gathered at the baseball game between Cedarville and Antioch. A smart shower stopped the proceedings for a short time, but when the game was finally ended Antioch was the victor.

The exercises given by the Y. W. C. A. in the Opera House in the evening completed the events of the great day. A large audience attended the program of songs, pantomimes, declamations, impersonations and sketches.

The success of this Cedar Day program was due to the untiring efforts of Miss Schneder and her efficient helper, Miss Alberta Creswell, together with the hearty coöperation of the student body and the Faculty.

F. F. T. 

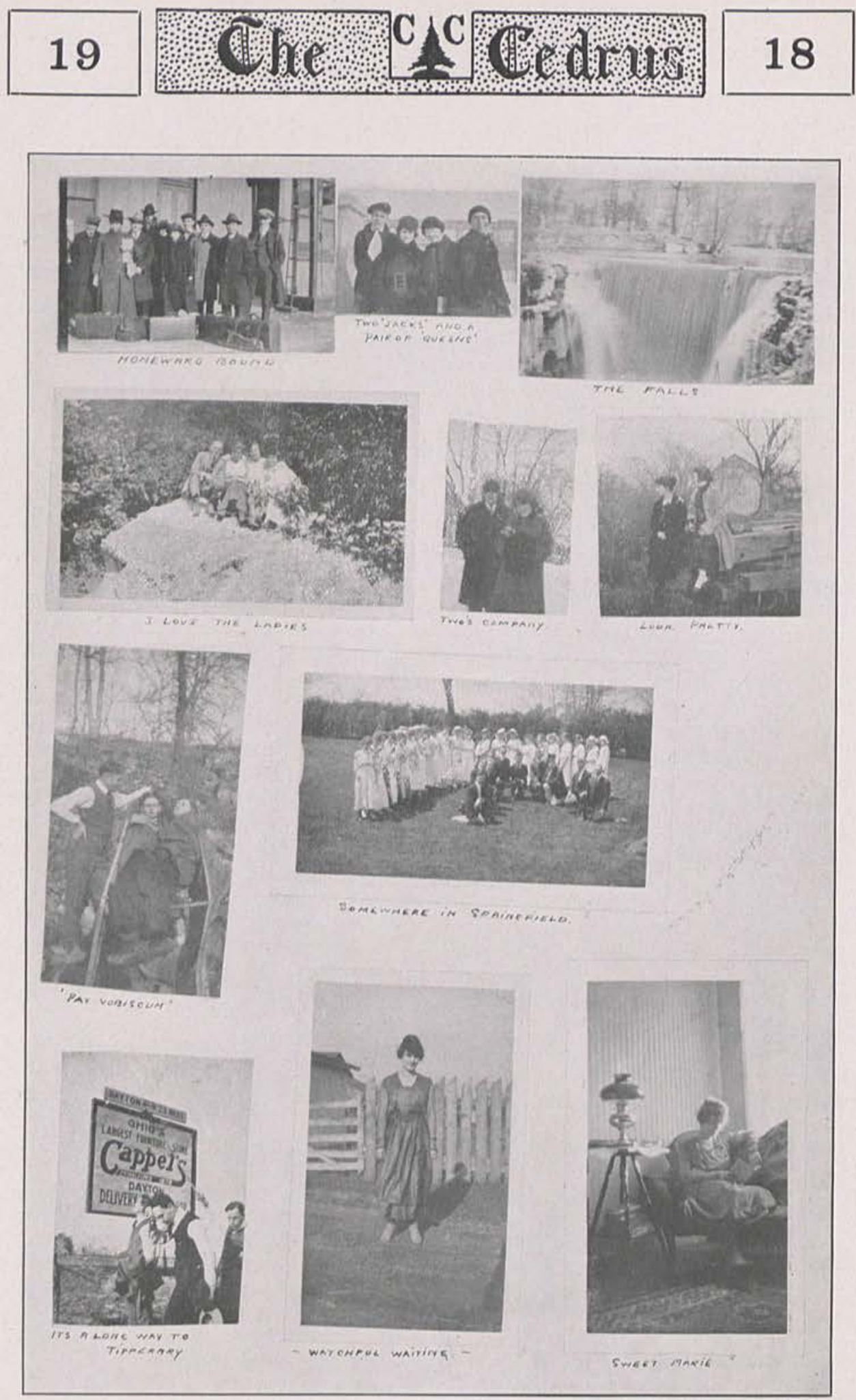


\section{9}

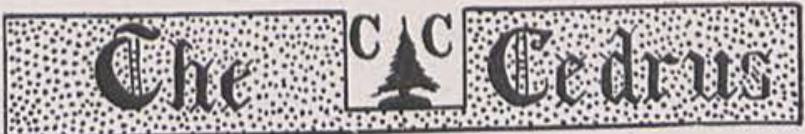

\section{THE BEST MAN WINS}

H IS exams of the first semester being over, Harry Cooper was packing his suitcase preparatory to leaving to spend a few days at home. Harry had not seen his father, mother and two sisters Hinin from home for for three months; and since he had to visit with great anticipation. Just as he closed the suitcase and was putting on his overcoat, he heard a loud knock at the door.

"Come in," he said.

"Hello, Harry! are you leaving?" exclaimed Jack Cameron.

"What's the attraction back home? Some girl, I suppose," said Lovell George.

"Not at all, Lovey; I'm going to spend a few days with my folks," he answered.

"Say, Harry, why don't you stay here," said Jack, "and practice basketball eyery day, and get on the good side of the coach? He will then let you play in the game against Oberlin."

"You can play center better than 'Bud' Harris, and if you would only convince the coach, you would get to play," said Jack.

"I'm sorry, boys, but the train will be due in five minutes, and I must go. But, fellows, before I go, I wish to say that if the coach thinks 'Bud' can play better than I can, I have no objections. Good-bye."

"Good-bye, Harry; good luck!" they answered in chorus.

"Thank you," came the faint reply.

"Say, Jack," said Lovell, in a low tone, "isn't it a pity that Harry is so honest. He must be afraid of hurting 'Bud's' feelings. Why, if I could play basketball as well as he can, I would be on the team instead of a 'sub.',"

"Those are my sentiments, too," answered Jack; "but let us study our Analyt. You know the exam, comes tomorrow and I do not want to flunk."

"That's me; so here goes," replied Lovell.

Harry had reached the depot and saw "Slim" Fulton.

"Hurry, Harry, the train is coming!" yelled "Slim."

"I'll be out in a minute," answered Harry, as he disappeared through the door to buy a ticket.

A large number of students were boarding the train as Harry came out, and being joined by "Slim" they hurried to the train. As they came up to the car they saw "Bud" Harris, with three other students disappear through the "smoker" door. Harry and "Slim" found seats in the car back of the "smoker." After having disposed of their suitcases, overcoats and hats, they discussed the examinations.

"Did you pass them all, Harry?" asked "Slim."

"Yes, I am quite sure I passed. But the Calculus exam. was rather difficult," was the reply.

"That is just the one I believe I flunked. It sure was a fright," added "Slim."

"No, you didn't, the exam. only counts one-third, and you had a class grade of eighty or more. You are safe. But, by the way, 'Slim,' I understand that 'Bud' has been smoking at times. Did you hear of it?'

"Yes, Harry, it's true. I saw him downtown after the basketball victory over Wittenberg. He was celebrating right."

"And going with Miss Ruth Angier; is it possible?"

"I guess it is, Harry, but I must leave you. Here is where I get off."

After "Slim" left him, Harry sat thinking. "Bud" was not only his 


\section{9}

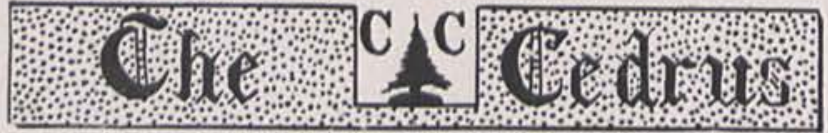

rival in basketball, but since he was on the team they had been rivals for Miss Angier. Before the basketball season, Harry paid considerable attention to Ruth. But since he had not made the team, her reply to his oftrepeated question was, "I'm sorry, but I have made other arrangements." The knowledge that "Bud" was paying attention to Ruth did not worry him, but the fact that he was losing out while "Bud" was winning, placed a great strain on his nerves.

Rising from his seat, he walked over to the door of the "smoker" and there stared in amazement at four boys, "Bud" among them, swearing, playing cards, and smoking. As he stood there thinking, he decided the proper thing for him to do was to make the team and thus win Ruth back. Awaking with a sudden start from his apparent dreaming, he said, "No, I will give 'Bud' another chance to show he is a gentleman."

Resuming his walk to his seat he realized that it was time for the train to arrive at the town where he expected to get off. Suddenly the brakeman called out, "Dunkirk, Dunkirk! Change cars to Sandusky, Cincinnati and Columbus."

Slowly drawing on his overcoat and picking up his hat and suitcase, he walked back to the rear of the car, and who should he meet coming from the other car but Miss Angier.

After stepping off the platform, Ruth exclaimed, "Is this Dunkirk?"

Harry, who was quite near her now, replied, "Yes, Miss Angier, this is Dunkirk. The town is on the other side of the track. It will look familiar to you after the train passes."

"I thank you, Mr. Cooper; I thought I stepped off at the wrong place."

"No, you are all right. But, by the way, do you change cars here?" asked Harry.

"Yes, I have a five-minute wait here, to take the train for Findlay," she replied.

"I am sorry, Miss Angier, for I should like to spend a few moments with you, but I see father and mother coming around the corner." And as he departed, he said, pleasantly, "I hope you will have a happy time."

"Thank you," she said, softly. And as she watched the manly figure hurry up and kiss his mother and greet his father, she said to herself, "He certainly is a good boy."

Harry was soon driving the machine homeward bound at a rapid rate, for he knew that his sisters were there to meet him. Reaching home, he greeted his sisters, and was soon out helping his father with the chores. Coming in, after the evening work was finished, he saw a sumptuous dinner awaiting him. As he had not eaten much for luncheon because of the anxiety of going home, he ate heartily. The conversation naturally drifted to Harry's college work, and he related such portions as he thought would be of interest to them. His talk was so interesting to them that it was midnight before they thought of going to bed.

Thus, Harry spent a few pleasant days at home, and the vacation was, as it seemed to him, entirely too short. But school work was to begin on Wednesday, and Tuesday found Harry back at College. As he entered his room "Tubby" Jones ran up to him and said, "Hello, Harry, you haven't forgotten about the game with Oberlin next Friday night, have you?"'

"Not at all, 'Tubby', I expect to be ready to take 'Bud's' place if he is disqualified."

"Did you hear that 'Bud' isn't showing up well in practice. They say he is living too high."

"Well, Roy, I hope it isn't so. But I will see you at the game." 


\section{9}

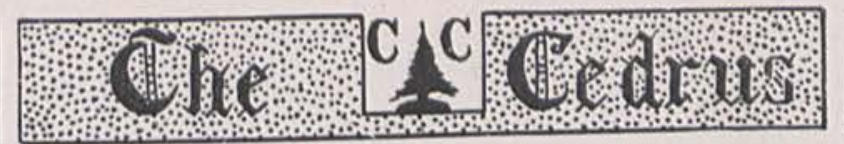

"I'll be there with bells on," replied Roy, as he left the room.

Friday night found the gymnasium packed to its limit. Harry and the other "subs" were sitting along the north side line. Just opposite and up on the running track, he noticed Ruth with her roommate, Miss Reed.

Instantly there was a clapping of hands as the Oberlin team entered and commenced practice. Shortly after, a tremendous uproar arose as our players entered. During the practice Harry was busy watching the players of the Oberlin team, and often looked to see how "Bud" was playing.

" 'Bud' isn't showing up very well in practice," exclaimed "Shorty" Fox, who was sitting near Harry.

"Why should he?" replied Joe Adams, "He, 'Deac.' Berry and two other fellows were up playing cards till three o'clock this morning. I am afraid he will not last long against Oberlin's big, tall center."

"But, see there; he made a basket," added Harry.

Their conversation was interrupted by the referee's whistle. The players took their places and all the people rose to their feet, the ball went up and the game was on. After several successful passes, the ball was passed to "Bud"; every body yelled, "Shoot!" and after steadying himself he shot for the basket and the ball went true to its mark.

But, alas for "Bud"! That was his fatal basket, for he now was too confident of himself and the lack of rest the night before weakened him so that he was unable to make another basket, and many times he would get in the way of our other players.

The coach noticed this and said to Harry, "Get ready to go in the second half, for 'Bud' isn't playing any more. He fails to follow my orders and persists in smoking, and just when I need him the most he is no good."

The whistle of the timekeeper announced the end of the first half. The people sat down with a sigh as they saw that the score now stood 10 to 16 in Oberlin's favor.

The players passed below and the band played several selections during the intermission.

The players soon came on the floor and as Harry passed through the door, he heard a great applause. He now knew that the people expected him to win. Crossing the floor he glanced up at Ruth. Very much surprised he saw that she was watching him with much interest.

The coach called Harry to him and said, "Harry, I am depending on you."

"I'll do the best I can," he replied, as he took his place.

And true to his word, Harry played as he never played before. And it was largely through him that the score stood 19 to 20 with Oberlin in the lead. With only sixty seconds to play everybody was up yelling till the building vibrated. Harry saw the ball going down towards Oberlin's basket; in a second he was there and intercepted the throw to the basket. Then, after several passes to the left forward, he made a desperate effort and threw for the basket. By the uproar of the people he knew that he had made two more points and put his team one point ahead of Oberlin. The timekeeper reported that the game was over.

Harry was not at all surprised when the boys congratulated him, but was elated when he saw Ruth coming to him.

"Congratulations, Mr. Cooper, you played a fine game," she said.

"Thank you, Miss Angier, did you enjoy the game?" And without awaiting her answer, he added, "Would you care to go to the lecture tomorrow night?"

"I would be delighted to go," she answered.

"Thanks," said Harry as he started to the locker rooms.

J. H. R. 


\section{9

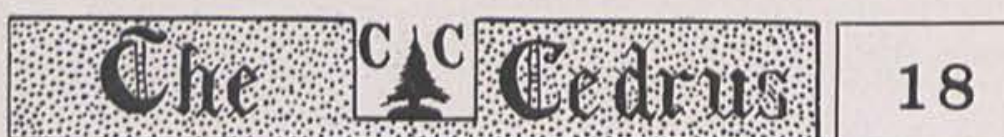

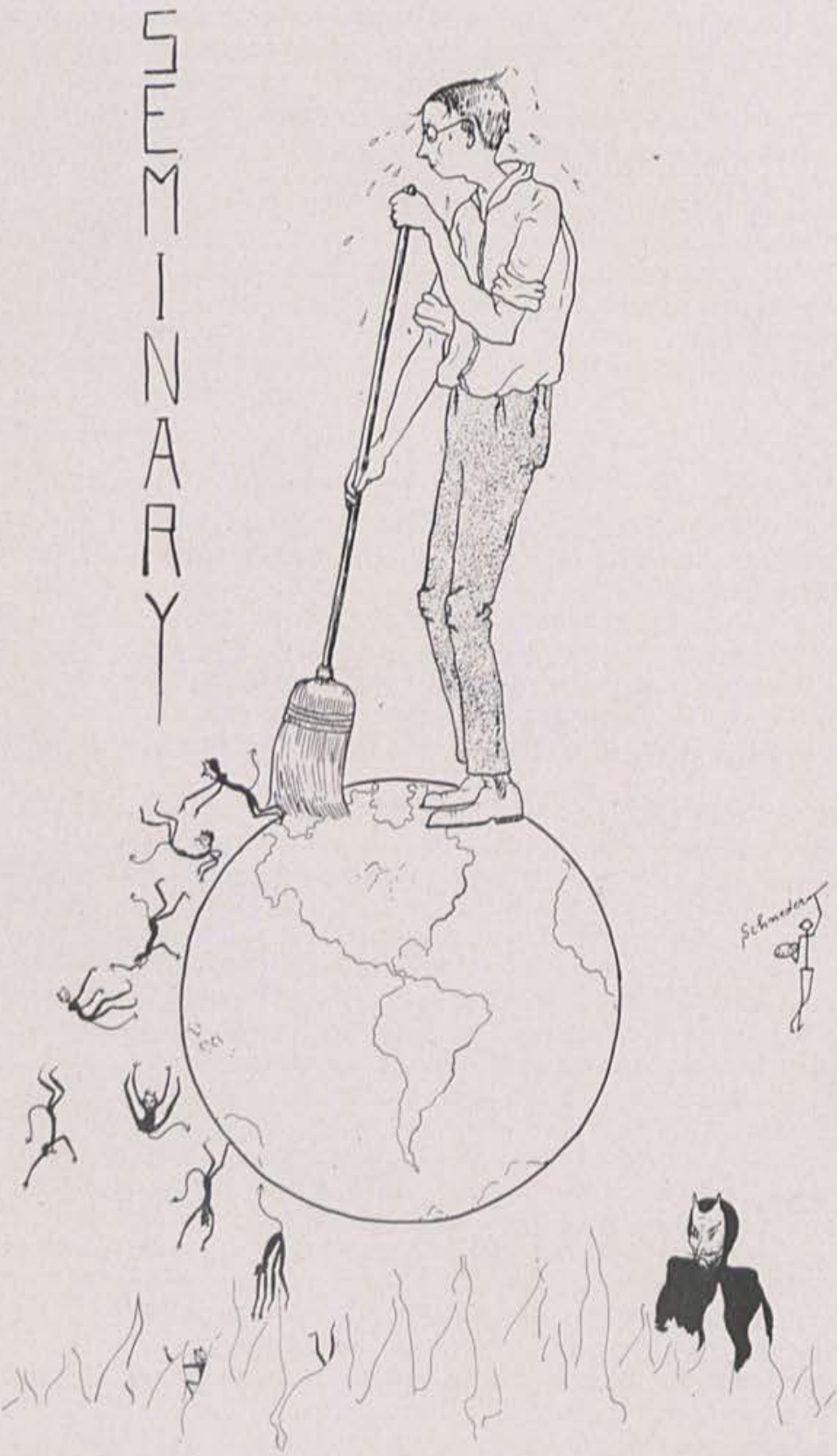




\section{9}

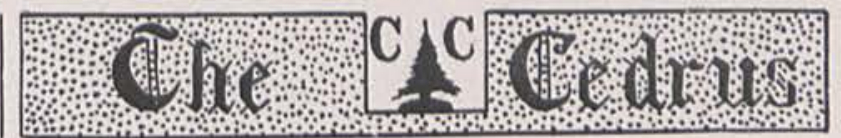

\section{CEDARVILLE THEOLOGICAL SEMINARY}

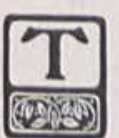

HE Theological Seminary of the Reformed Presbyterian Church, General Synod, was organized May 25, 1810. The following ministers of the Gospel either have served or are serving as professors in the various departments:

S. B. Wylie, D. D.

John Black, D. D.

James R. Wilson, D. D.

Samuel W. Crawford, D. D.

T. W. Wylie, D. D.

Gilbert McMaster, D. D.

Hugh McMillan, D. D.

John N. McLeod, D. D.

David Steele, D. D.

A. Thompson, D. D.
W. J. McDowell

Matthew Gailey

James Steele, Ph. D.

James Y. Boice, D. D.

W. J. Smiley

David McKinney, D. D.

W. R. McChesney, D. D.

F. A. Jurkat, LL. D.

Leroy Allen, Ph. B.

James L. Chestnut, D. D.

The Seminary offers the following courses of study. (1) Regular Seminary Course of 3 years, (2) Combined Arts-Theology Course of 5 years, and (3) a Graduate Course in Theology.

Course (1) is designed to fit young men for the gospel ministry, and leads to a diploma of graduation. Course (2) is for theological students who have had little or no college training. It gives a liberal culture and fits for active work. It leads to the Degree of Bachelor of Arts from the College and a diploma from the Seminary. Course (3) is for graduates of either of the above courses and of other Theological Seminaries.

It leads to the Degree of Bachelor of Divinity. This year the students represent both Reformed Presbyterian denominations and the Presbyterian Church. Students of all denominations are welcomed. The Seminary stands for the highest cultural and spiritual training.

The Faculty at present are: W. R. McChesney, Ph. D., D. D., President of Cedarville College and Professor of New Testament Language and Literature; F. A. Jurkat, A. M., LL. D., Professor of Church History and Old Testament Language and Literature, and Leroy Allen, Ph. B., Professor of Homiletics, Biblical Theology, Archaeology and Sociology.

W. R. MCChESNEy. 


\section{9}

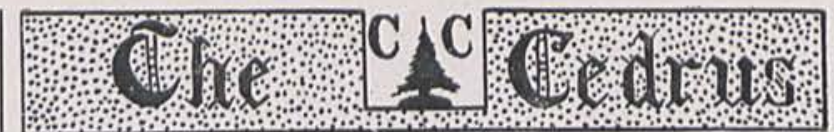

18

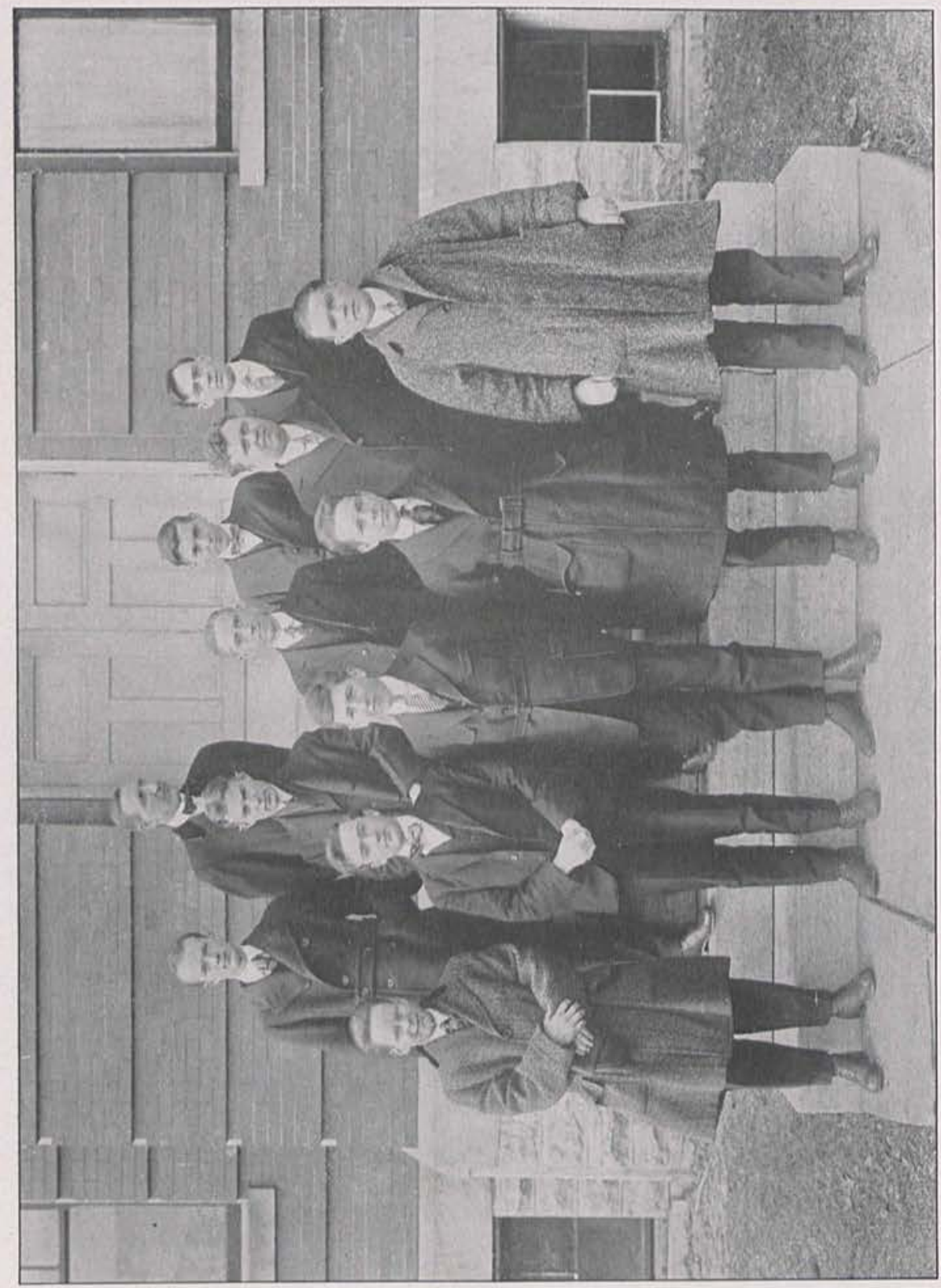

들 


\section{9}

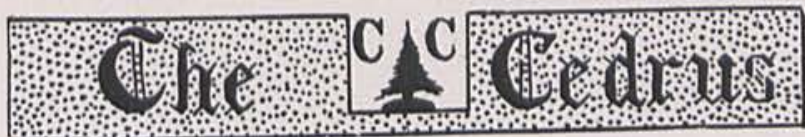

\section{DR. JAMES L. CHESNUT, D. D.}
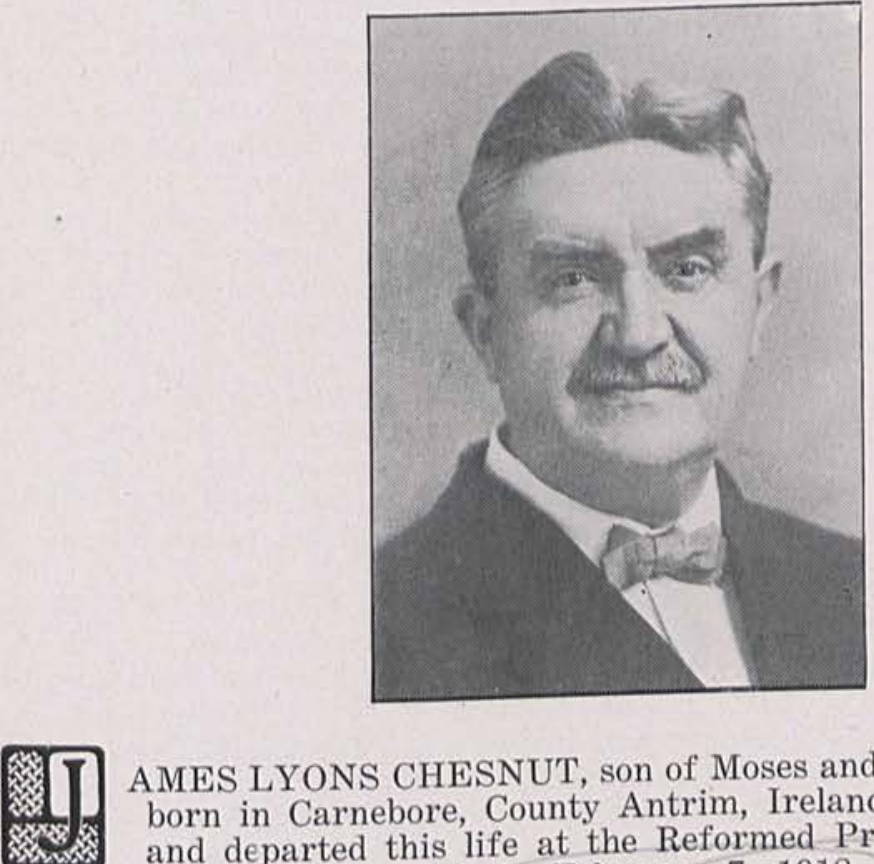

AMES LYONS CHESNUT, son of Moses and Martha Chesnut, was born in Carnebore, County Antrim, Ireland, on March 21, 1867, and departed this life at the Reformed Presbyterian parsonage, at ten minutes of two o'clock, February 7, 1918, aged fifty years, ten months and seventeen days. The funeral services were held in the Main Street Reformed Presbyterian Church, of which he was pastor, at 1:30, Saturday afternoon, February 9, 1918. This date was almost to the hour, twenty-five years after Dr. Chesnut was ordained and installed pastor by the Western R. P. Presbytery, over the Grand Cote R. P. congregation, Coulterville, Illinois, which was his first charge.

Dr. Chesnut had two sisters, one of whom died in infancy, while the other, Mary M. Chesnut, and the mother, live at Bush Mills, Ireland, the father having entered his eternal rest a few years ago, at nearly this time of the year.

Dr. Chesnut received his education in the common schools of Ireland, the Colerain Academic Institute, the Reformed Presbyterian Theological Seminary, then located in Philadelphia, and the post-graduate department of the University of Pennsylvania, pursuing a course of philosophy in the latter. He graduated from the theological seminary April 5, 1893, having been licensed the previous year, by the Philadelphia Presbytery, to preach the gospel.

Dr. Chesnut served as pastor of Grand Cote from February 9, 1893, until he left for Cedarville, Ohio, twenty years later. He ministered efficiently and faithfully and was widely known and beloved throughout southern Illinois.

The Cedarville R. P. congregation gave him two unanimous calls, the second of which he accepted in the fall of 1914 , and with his family moved 

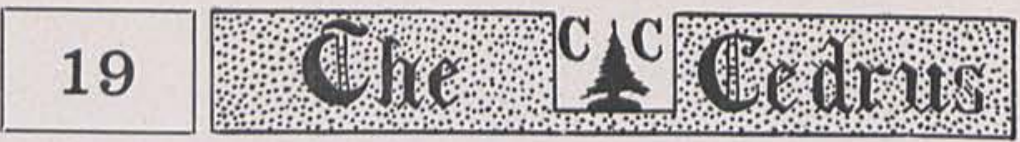

to Cedarville in February, 1915, and was met and welcomed at the train by the faculty and students of Cedarville College and a large number of the congregation.

If Cedarville received him enthusiastically, Coulterville, on the other hand, reluctantly, but with splendid Christian resignation, yielded up his services. Dr. Chesnut was installed over the Cedarville congregation during the meeting of General Synod in May, 1915, on the Sabbath, and the Rev. W. J. Smiley, long associated with him in the Western Presbytery, preached the installation sermon, while Dr. Alexander Savage gave the charge to the people, and Dr. W. R. McChesney charged the pastor and installed him. Dr. Chesnut, during his pastorate of nearly three years, won his way into the hearts of all throughout this community as well as in his congregation, in a way surpassed by no other who ever lived in our midst. He has left an everlasting benediction with us.

He emigrated to the United States when a lad, accompanied by his parents and sister; but his parents and sister, from a desire to return to their native land, soon left the country, while James remained and became a clerk in the office of the Pennsylvania Railway Company, at Philadelphia. He used the earnings of this position to secure a fuller education, and to enter upon and complete his theological training.

On January 17, 1893, he was united in marriage to Miss Jennie Wallace, of Philadelphia, who survives to mourn the sundering of the tender ties of true love and happiness, which had bound them together for a little more than twenty-five years. To them were born two children, Mary, a graduate of Cedarville College and James, a Senior in Cedarville College, and a student in the R. P. Theological Seminary. The affection between father and children was true, tender, close, ideal.

Dr. Chesnut occupied various positions in the Presbyteries to which he belonged; served as moderator of General Synod; was, for years, a superintendent of the R. P. Theological Seminary; stated clerk of General Synod, and the most efficient and beloved secretary of the Board of Foreign Missions. In 1901 the honorary degree of Doctor of Divinity was conferred upon him by Cedarville College. In 1915 he was elected a member of the Board of Trustees of Cedarville College and upon entering his office was chosen secretary of the Board.

He carried the honors bestowed upon him with becoming humility and commendable dignity. He served in the offices to which he was chosen conscientiously, efficiently, and prayerfully. The Church recognized his talents as superior and his spirit as that of a man of God, and consequently entrusted him with the most sacred and responsible position within its gift; and he never betrayed a trust or lowered a confidence, but rather did he inspire courage, faith and action by his well-known good cheer and unwavering loyalty to Christ and the Church.

Four communities at least, southern Illinois, Philadelphia, Cedarville and his native neighborhood away across the sea are alike sensibly touched and deeply moved.

Naturally, more than by all these he will be most missed in his home and among his dear loved ones. Likewise to them the sweet memory of his life will be most refreshing. Much as they will miss him; more in time to come, will his life, his love and all that made for the true husband and the devoted father in him grow upon them and heal their broken hearts and give calm peace to their souls. 
Were he here now to speak for himself, it seems to me, that he would say to his family: "We have had much to be thankful for, God has been good to us. He gave us many happy, blessed years together. This is his way. His will be done. I cannot come to you but you can come to me."

To his congregation he would say as he did once and again during his illness in the message he sent to us. "I love you." And, brethren, that pure, self-denying love should draw us closer together as a congregation and, in his own words, "make us a bit more thoughtful of one another, and kindly to one another." As he was true to Christ, he would have us remain true. As he was loyal to the Church he would have us continue to be loyal. Once more he would say: "Serve. Do earnestly and thoroughly the work committed to you. Build one another up in the things which make for salvation. Reach out and gather in the lost and especially keep a lively, loving interest in the children." These three words were his watchwords in his work: Love, Loyalty, Labor. God gives them to you to take as your watchwords as a congregation.

$\mathrm{He}$ anticipated the grief which would come when tender ties must be sundered and cherished hopes of time abandoned, and as he approached that hour he did so with calm trust in Christ, earnest invitations to others to join by and by in the heavenly home, expressions of heartfelt appreciation to all who called upon him as well as for many who could not see him, and gratitude to God for his manifold blessings bestowed upon him and his through all their lives, and for His unfailing grace, which sustained him while heart and flesh were fainting and failing.

Permit us to draw just a little the veil which discloses his home life. He was there as you knew him in the walks of life. He was a loving husband, faithful and devoted; a kind father, wise and affectionate, and, in turn most genuinely beloved by his family. He was a delightful host to all who entered his home. One felt that he must not trespass upon the time of this busy man; and yet one yearned to go to his home and was loath to leave, and was always repaid, whether Dr. Chesnut was in health or sickness, by a visit to his home. He was held in the highest esteem by the Ministerial Association, both as a man and a minister of the gospel.

Two congregations, Grand Cote and Cedarville, sincerely mingle their tears at his departure but mutually rejoice that they can claim him as their pastor and exult in his glorious coronation. Three Presbyteries place their tribute of love upon his casket. The entire General Synod feels his loss deeply and holds his work and memory precious and lasting. Our foreign missionaries know well his worth and will realize keenly their deprivation of his counsel and efforts.

He was the human center and life of every church court and of most of its committees. He was a staunch Reformed Presbyterian, devoted to all of the interests of the church and yet broad enough of vision and big enough of heart to recognize the good in all Christians and to co-operate heartily with all the followers of Christ in the advancement of the Kingdom of our Lord and Savior.

After he settled in Cedarville, he was chosen dean of the Reformed Presbyterian Theological Seminary and to the chair of Systematic and Pastoral Theology, both of which positions he occupied at his death. As director of the Seminary, he was unassuming and untiring in his efforts for its welfare and watchful of its every interest. As a professor, he always had attractive matter of practical value for his classes. He loved 

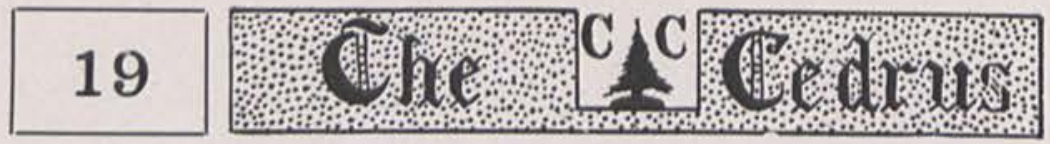

his students, took personal concern in them, and had their implicit confidence and genuine affection. His reputation as an efficient and exemplary pastor began with his ministry in Coulterville, grew with the passing years, went beyond the confines of his parish through the bounds of the entire denomination and came to the ears of the congregations of other denominations.

In his ministering to all classes, the old, the middle-aged, the youth; the ignorant, the learned; the high, the low; the rich, the poor; the churched, the unchurched; the white, the colored; his ability and tact to adapt himself to all and render them a real and lasting good was unexcelled and seldom has been equalled.

On account of his superior talents and traits, congregations of other denominations sought his service; but while he appreciated the opportunity thus extended, he preferred to remain true to the church of his choice and keep his covenant vows, though by so doing he sacrificed materially. He served the Lord, but not for any worldly gain. For that end he was absolutely beyond thought and temptation.

Dr. Chesnut was not a doctrinal preacher, nor was he a practical preacher. He was both. He so blended doctrine and duty and delivered his message with such power and geniality as to hold readily the attention of his hearers and imbue them with a true regard for God's word, a firm resolve to serve. He loved to preach and to minister; and it was only by the utmost persuasion that he was induced to refrain from his labors when his physical ailments had so fastened upon him as to render him unable to discharge his duties. Through several years, Bright's disease, with complications, insiduously fastened itself upon him, and began to attain its climax about a year ago. As the weary weeks, with their anxiety, pain and tossing, grew into long months, it was seen that his recovery could not be expected.

Notwithstanding his long illness, utter physical weakness betimes, and his intense suffering, especially in the past few weeks, during it all he preserved that genial, whole-hearted spirit which characterized him through life and made him the joy of every person who knew him and of every social circle he entered; and yet he realized to the full the approaching end and all that it would bring in the breaking of well-meant and laudable plans.

We turn to the Scripture for words forming a fitting commentary on his life and personality. The Old Testament would bring these: "Know ye not that there is a prince and a great man fallen this day in Israel?" While the New Testament offers these: "He was a good man, and full of the Holy Ghost and of faith."

And well we might have exclaimed with Paul, as like him he approached the end: "I am now ready to be offered and the time of my departure is at hand. I have fought the good fight, I have finished the course, I have kept the faith. Henceforth there is laid up for me the crown of righteousness, which the Lord, the righteous Judge, shall give to me at that day: and not to me only, but unto all them also that love His appearing."

Fond husband, loving father, faithful pastor, loyal churchman, true friend, genuine Christian brother, farewell, "until the day breaks and the shadows flee."

DR. W. R. MCCHESNEY. 


\section{9}

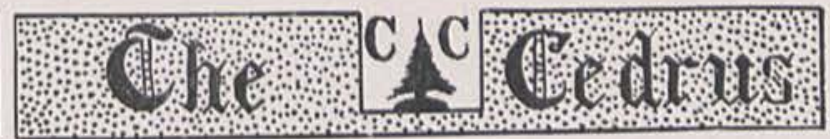

18

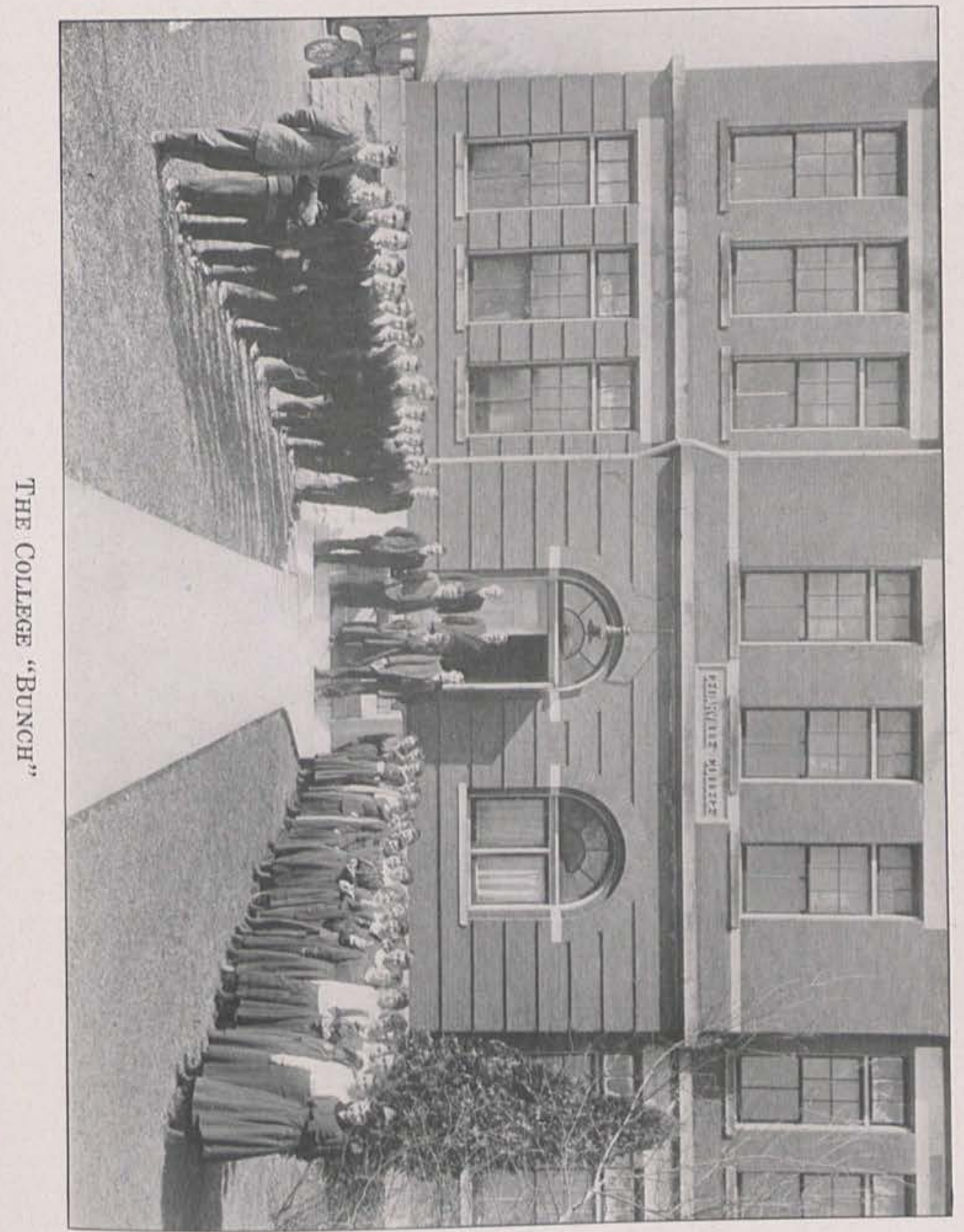




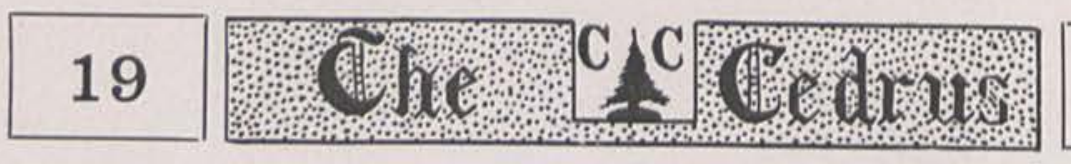

\section{8}

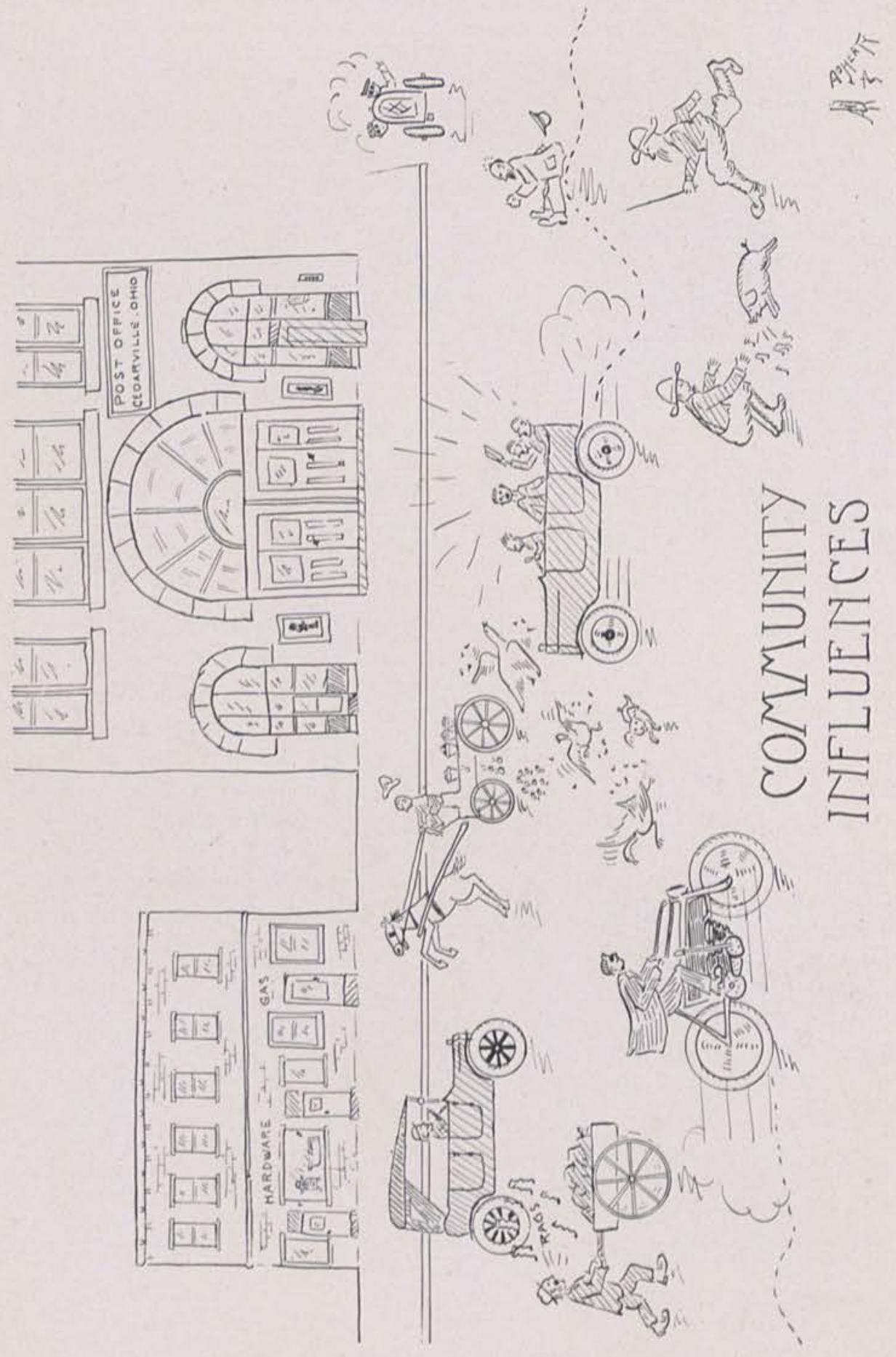




\title{
REFORMED PRESBYTERIAN CHURCH
}

\author{
MAIN STREET
}

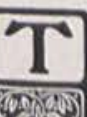

HIS congregation was organized by the Rev. John Black, D. D., of Pittsburgh, Pa., in 1809. During its one hundred and nine years of existence it has occupied five church buildings. The present edifice was erected in 1902. The following men have served as its pastors: Revs. Hugh McMillan, D. D., J. F. Morton, D. D., A. B. Henry, Mills J. Taylor, and J. L. Chesnut, D. D.

This congregation is the church home of the college and its students. It has 250 members. It is well-organized and active along all church lines, liberal in its contributions to the College, Home and Foreign Missions, the American Bible Society and other evangelical lines of service.

It has a splendid Sabbath School and a wide-awake Christian Endeavor Society. All are welcomed to all of the services of this congregation and will enjoy the fellowship and spiritual good they find there.

REv. WILBERT R. MCCHESNEY. 


\section{9}

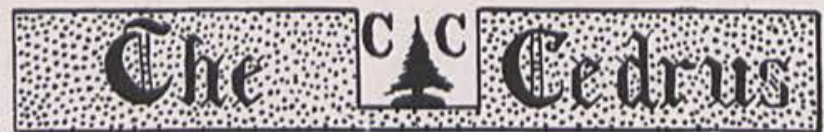

\section{METHODIST EPISCOPAL CHURCH}

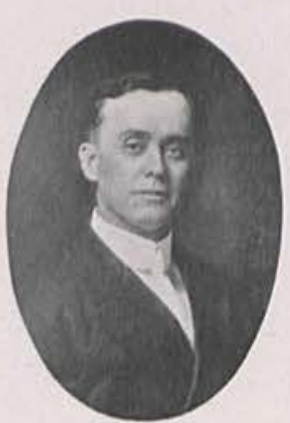

Rev. Jos. W. Patton

INCE the early "circuit rider" of the Methodist people was not far behind the pioneer and family, it is not at all surprising to learn that the present society had its beginning some time about the year 1810. Their own church records show that about this time a class was organized at Union (Spring Valley) and in all probability Cedarville together with many other points were operated together. And so tradition informs us that in the year 1810, "meetings" were being held on the site of the building now occupied by Mrs. Elizabeth Shroades.

In the early "twenties" Quarterly Conferences and regular Communion services were being held at that place. This meant that a Society had been regularly organized, and its pastor and times for preaching and at stated intervals received official recognition and visits from the "Presiding Elder."

As early as 1830, according to Court Records, the class had outgrown its place of meeting. A lot was purchased and a church was erected on the site of the present building. Some of the original ground was sold and other bought until the property became the present size and proportions.

By 1853 it was necessary to replace this building with another and larger. This was indeed a church of some proportions when the period is taken into consideration. For many years this was the place where the "Circuit Rider" preached, revivals were held and souls added to the Kingdom. This same building is the present auditorium, the whole building having been changed and enlarged during the pastorate of Rev. W. E. Putt, D. D. The present building now has a modern room for all Sunday School services, prayer-meetings and social meetings and also Sunday School class rooms. The Sunday School has its piano and the church a pipe-organ. By an action on the part of the officiary of the church, any member is allowed to take lessons on the organ provided he will play for the church services should occasion arise.

The Sunday school is under the able leadership of Mr. L. H. Sullenberger. The present pastor, Jos. W. Patton, is just now closing his fifth year as the pastor. Rev. Jos. W. PATton. 


\section{9}
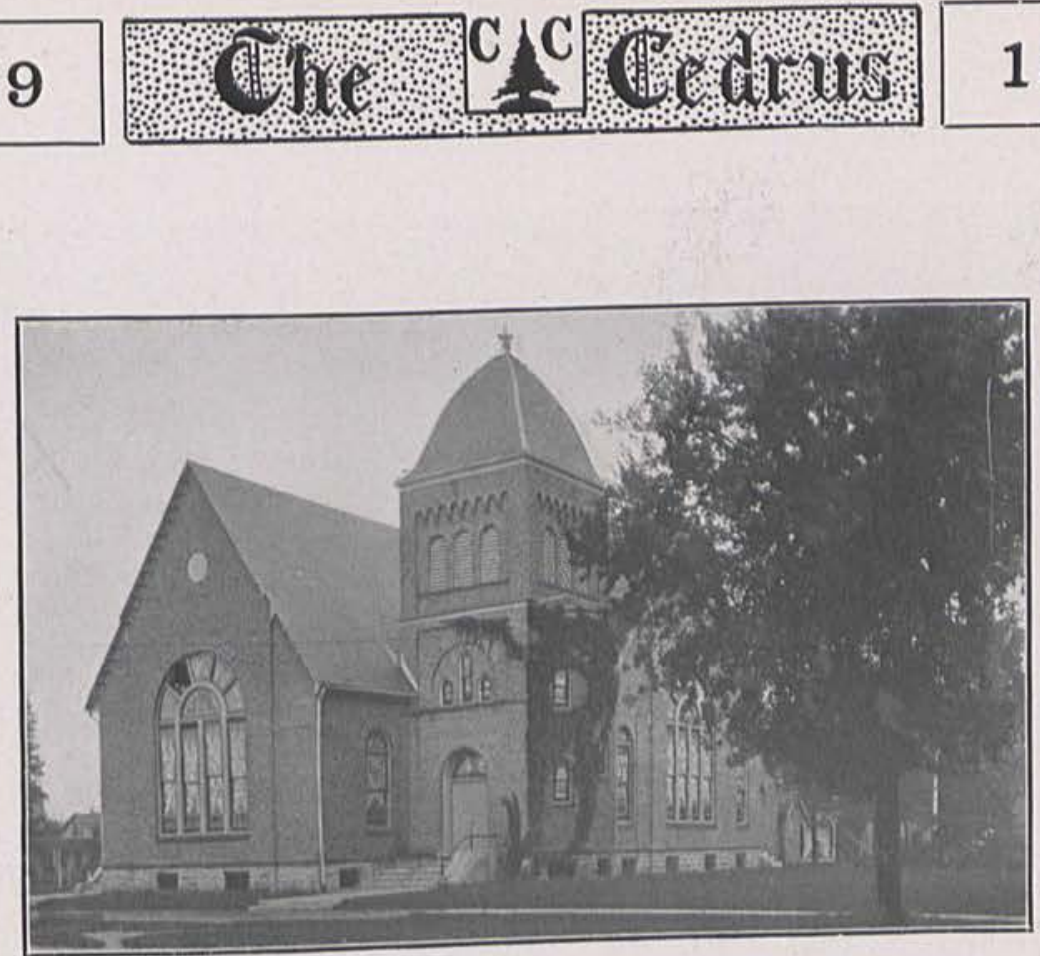

\section{UNITED PRESBYTERIAN CHURCH}

$\mathrm{N}$ the summer of 1844, a little group of Associate Reformed Presbyterians, living near Cedarville, petitioned the Springfield Presbytery of that church for the organization of a congregation in ist. The request was referred to the Second Synod for final action and on being acted upon favorably, the organization was duly effected on November 6, 1844. With the union of the Associate and Associate Reformed Churches in 1858, the local congregation became the United Presbyterian Church of Cedarville.

Thru almost seventy-five years that have been marked by the usual vicissitudes that fall to the lot of all congregations, the Cedarville Church has maintained a vigorous life and a healthy growth. In all matters pertaining to the betterment of the community, it has taken a prominent part. It has served the Kingdom well in sending into its ranks of the ministry almost a score of its young men. Its interest in and contributions to the missionary work of the United Presbyterian Church have won it a place in the foremost ranks of the denomination. At present the congregation enrolls a membership of slightly over two hundred and fifty.

During its history, the congregation has been served by eleven ministers. The present pastor, James S. E. McMichael, was installed as such on December 16, 1910. 

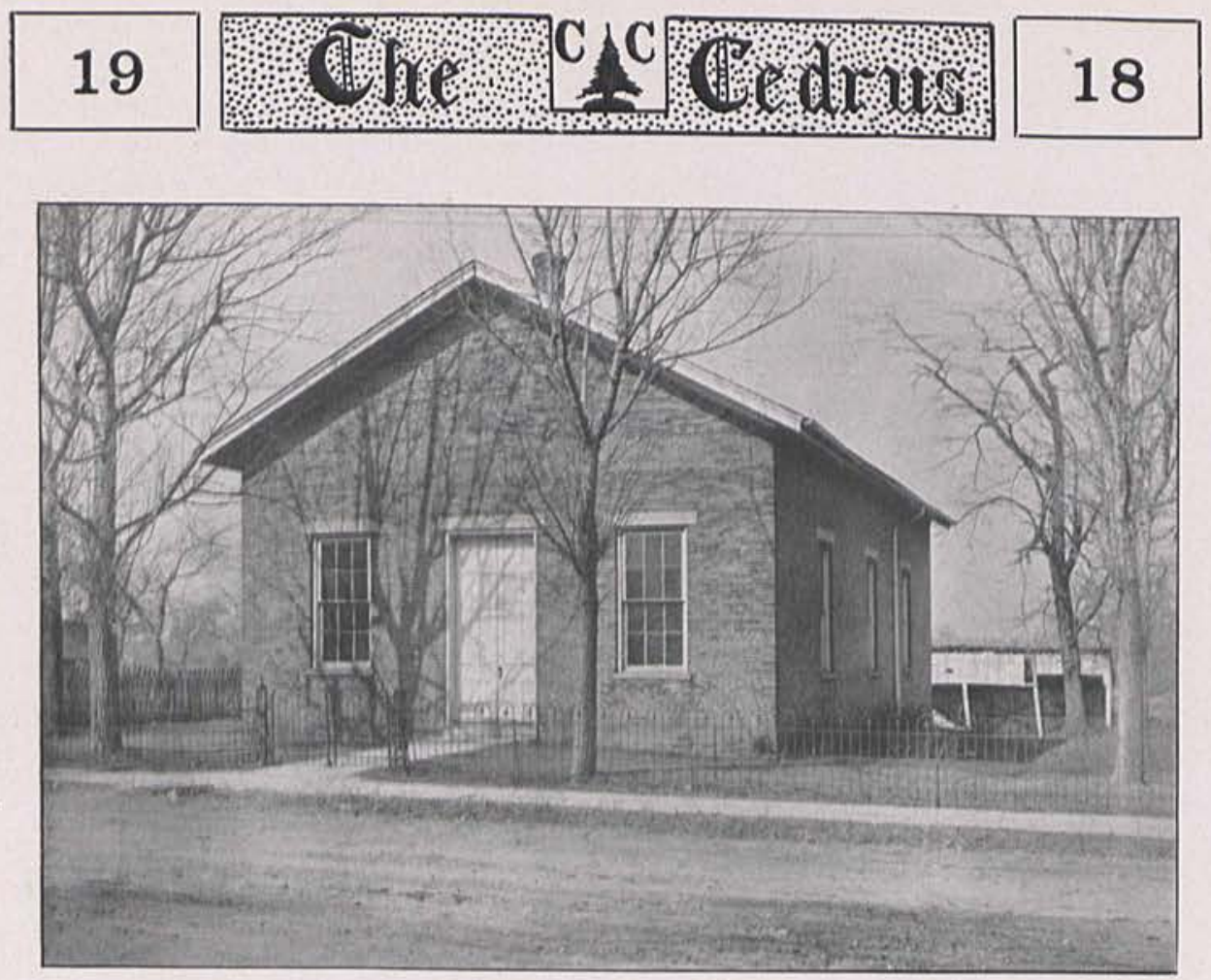

\section{THE COVENANTER CHURCH, XENIA AVENUE}

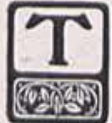

$\mathrm{HE}$ membership of this church has a lofty conception of the mediatorial claims of Christ Jesus. In all things, $\mathrm{He}$ is given preeminence.

All through its history, its highest aim has been to maintain Christ's rightful place in a redeemed world. He should reign supreme in the heart, in the home, in the church and in the nation.

The founders of this church had a clear vision of Christ's kingdom in its relation to both church and state. In both, Christ reigns supreme as King. And His supremacy is the glory of each. No other church has contended for the claims of the Christ over the nations more persistently and faithfully, than the Covenanter Church. The Word of God has given to this people a splendid vision of what their country ought to be, enlightened with the gospel, governed in righteousness, and protected by Omnipotence. As descendants of those who were unwilling to see their Savior dishonored by Pope or King, and willing to die for His sake, we still adhere to these great principles which, by the grace of God, have brought a redeemed world nearer to God and the fullest enjoyment of Christian democracy. In the world's present crisis, our country needs the leadership of King Jesus - "One mighty to save." Let us, all in this impending struggle, hear the cheering words of Christ saying: "I am the way, the truth and the life."

Too long, as a nation, have we rejected Him who is the only way of true peace.

Too long have we refused Christ as the divinely appointed "leader and commander to the people." But He is long-suffering and ready to forgive.

Hence our message to the world may be summed up in these words: "In all Thy ways acknowledge Him, and He shall direct thy path."

Rev. W. S. Fulton. 


\section{9}

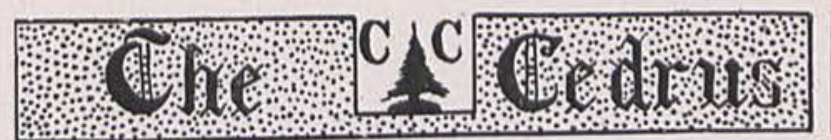

18

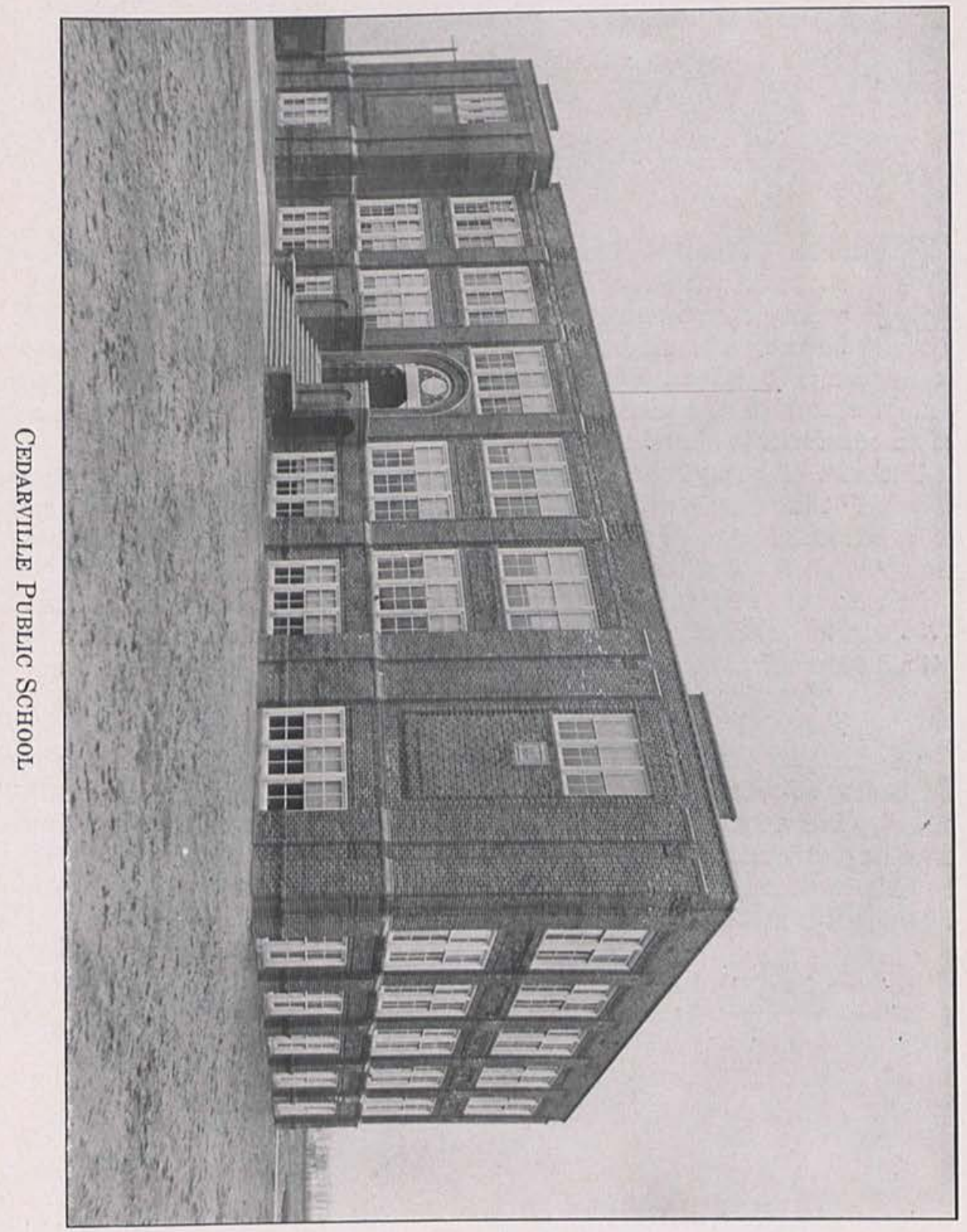




\section{9}

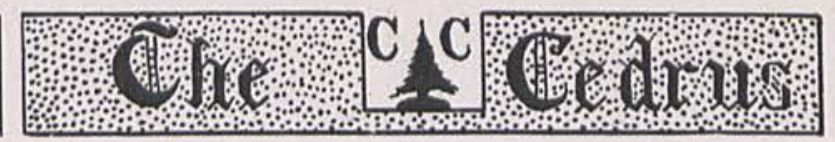

\section{THE AIM OF THE SCHOOL}

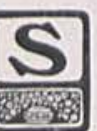

INCE Cedarville Township has such a magnificent building as shown in the above cut, the teachers and the pupils have a much stronger incentive for doing the things which a school should do. The old building was so dingy and worn that it was impossible to teach many things to children which should be taught with satisfactory results. The overcrowded condition led to a laxness in requiring those not desirous of an education to attend regularly.

The aim of any public school should be to produce the best possible citizens. This requires the best that any school can give, working under most favorable conditions, in spiritual, intellectual, moral, and physical training. Any school that fails to do this is not doing its full duty.

The aim of every teacher in the school is to make it equal to the best. This can be done only by getting every pupil who should be in school to attend regularly, and then to get each one to do his or her best in every respect. This goal is not beyond the reach of any school, but there is a great amount to be done before we can reach it.

The teachers alone cannot bring this to pass, but they must not only have the hearty co-operation of every parent who has a child in school, but also of every individual within the school district. The teachers feel that they have the coöperation of the majority of the people. We trust that we may be able to arouse their interest and thus make conditions such that the best possible results may be obtained.

L. D. PARKer, Principal. 


\section{9}

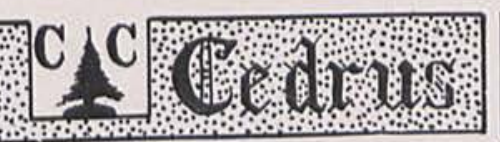

18

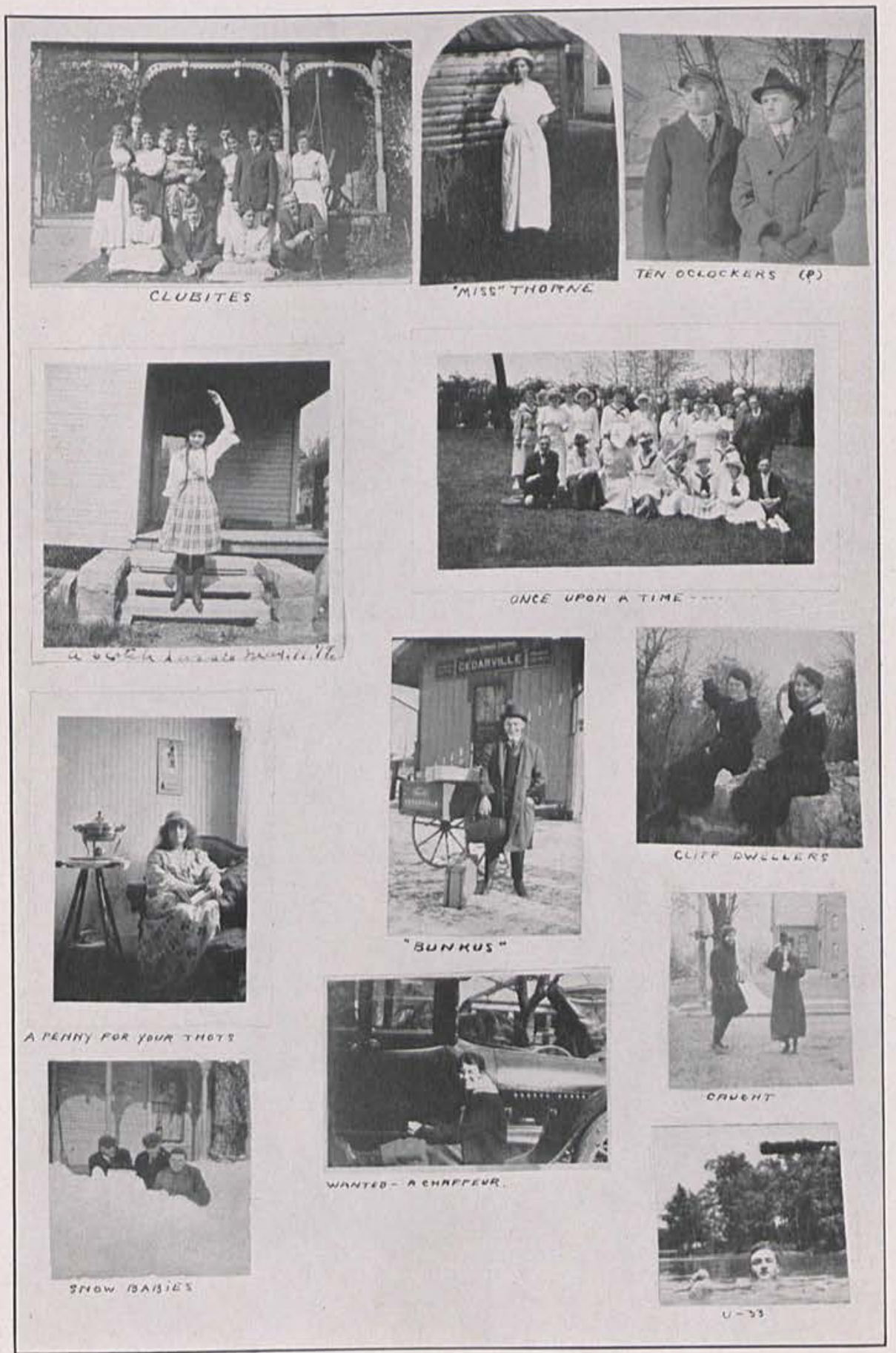




\section{9}
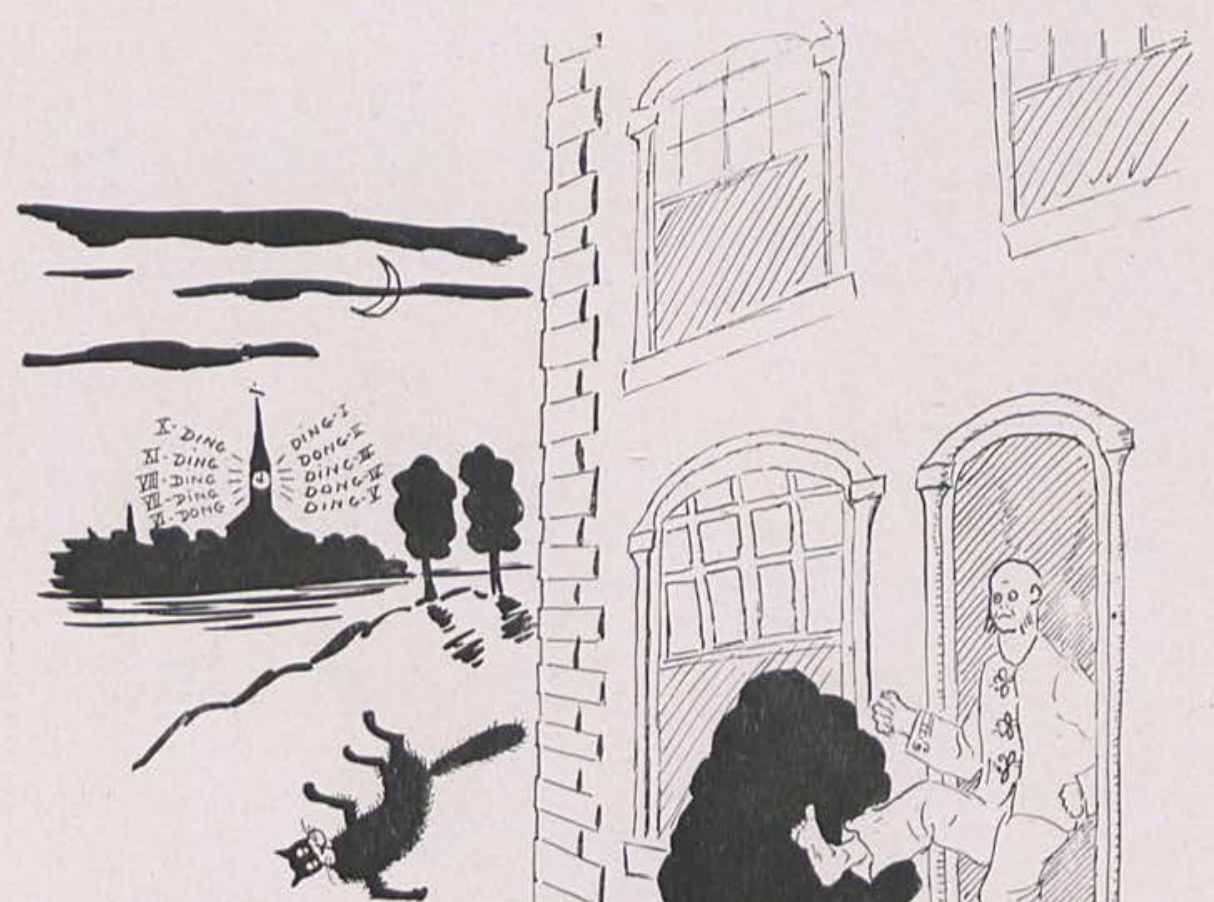

1
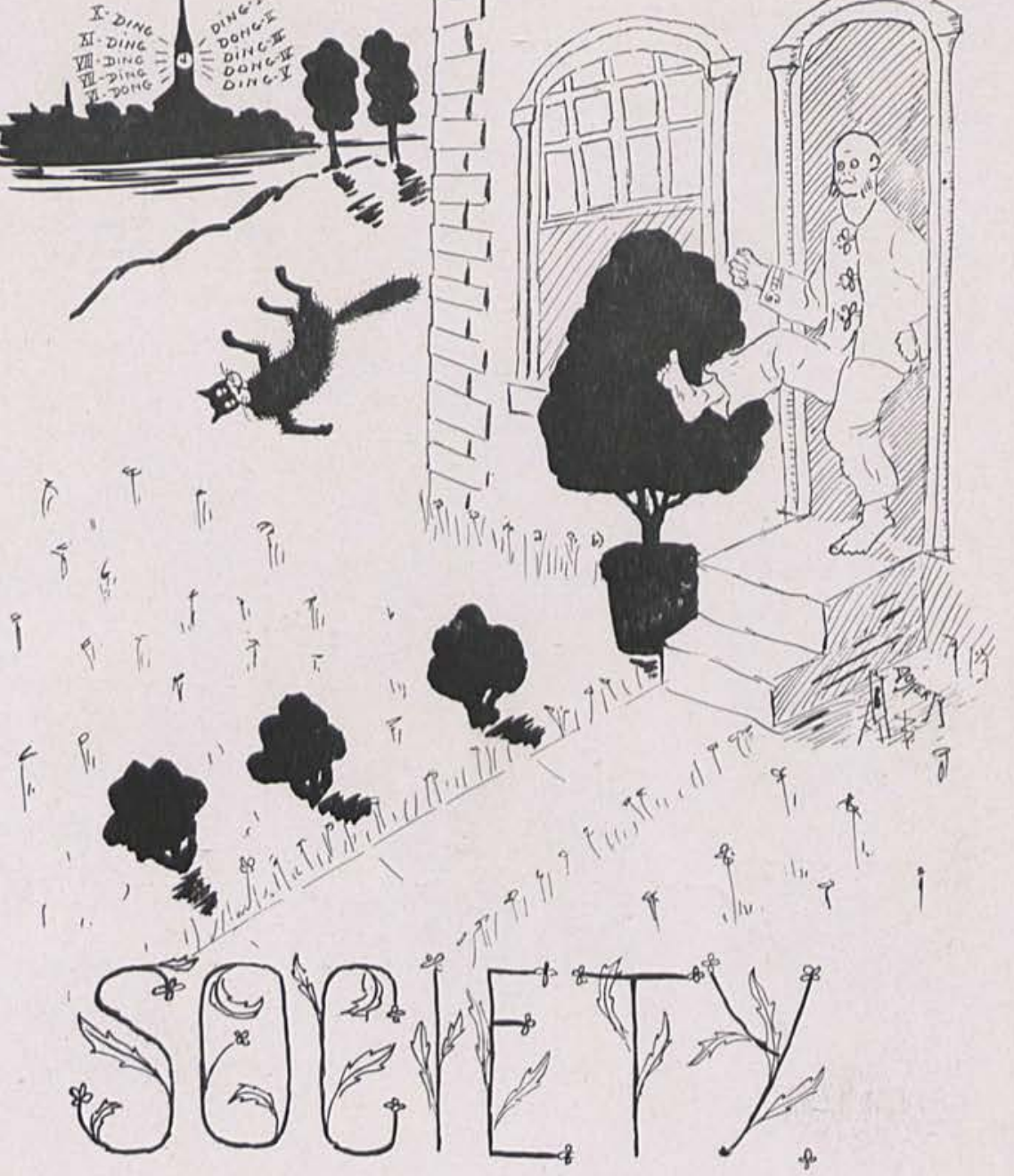


\section{9}

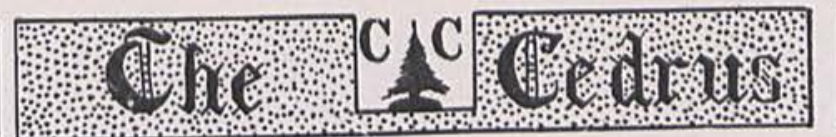

18

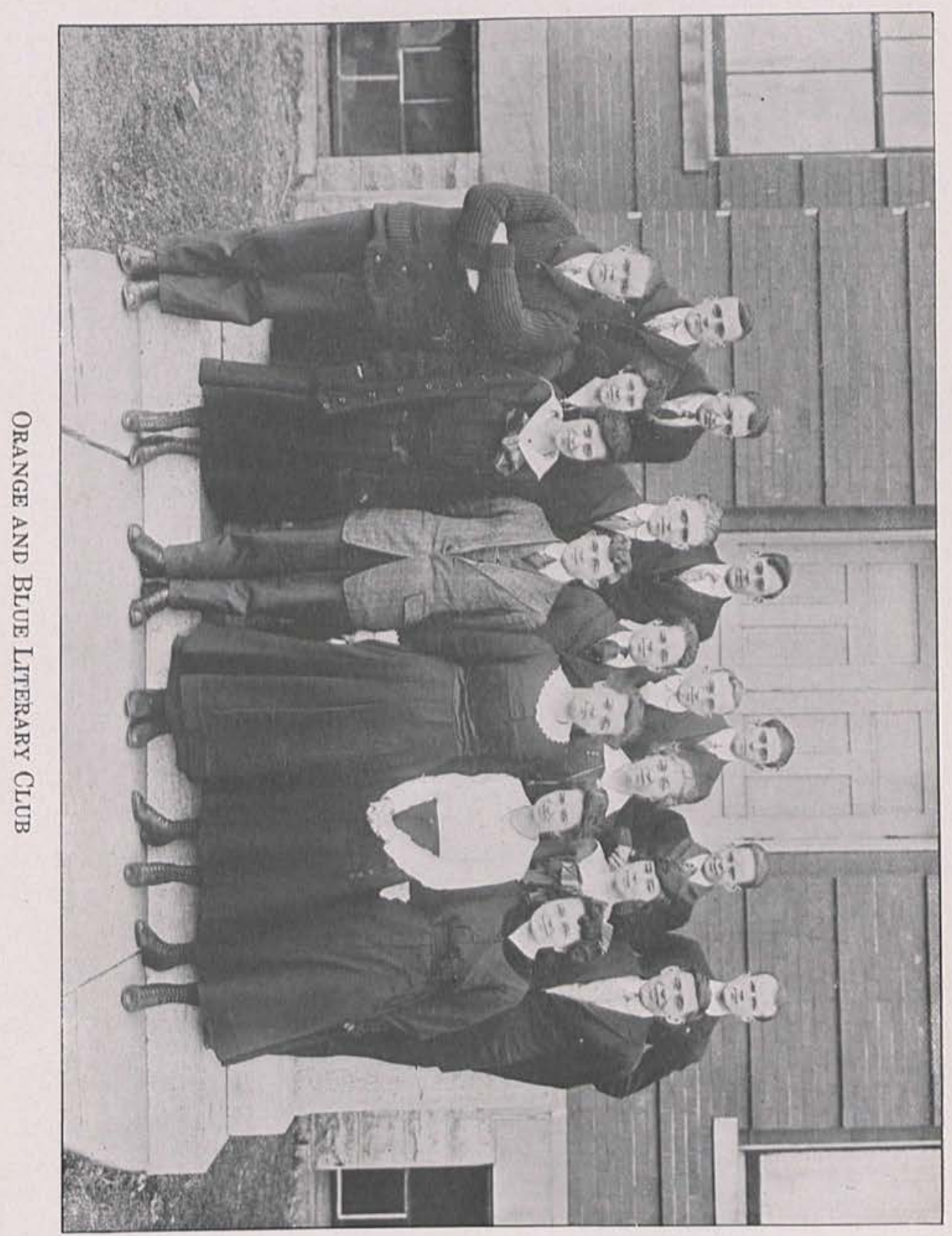




\section{THE ORANGE AND BLUE}

In a college in Ohio

Where the skies are always blue,

A society was founded

Which was named Orange and Blue.

Gladly did the students join it,

For it met a pressing need;

Twenty-five good charter members

Made a splendid start, indeed.

We will gather every fortnight,

In college society hall,

And each one will there be welcome

Whether thin, fat, short or tall.

The time will be spent profitably,

And pleasantly as well,

With music, talks, papers and speeches,

Debates, essays and stories to tell.

We hope the students one and all

Will join us each meeting eve.

We're sure you will enjoy it,

And regret when it's time to leave.

And when our college days are o'er

We will search our memories thru,

And think with joy the hours we spent,

In our dear old Orange and Blue.

M. M. G. 


\section{9}

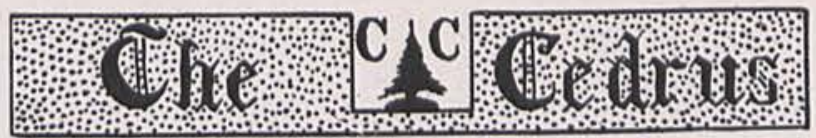

\section{HALLOWE'EN PARTY}

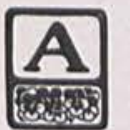

FEW days previous to Hallowe'en, the college lads received an invitation to a party. Directions were given to mask and assemble at the College Hall at $7: 30$ o'clock on that eventful evening. When all the boys had arrived, they were directed to another part of town, and from thence to another place and so on, until finally they arrived at the home of Miss Alberta Creswell, one of our former C. C. instructors. Here they found a crowd of ghostly figures who, strange to say, seemed to have lost all power of speech. After trying out "who was who," the ghosts and their guests seated themselves on the floor in the large living room, which was weirdly lighted by the grate fire, while Miss Schneder told a ghost story. The story was made quite realistic when the narrator threw into the audience a clammy hand and leg, and a slimy eye. The shrieks and the cries of the listeners proved that their imaginations were properly aroused.

After unmasking, the guests visited a corn-husk booth where appropriate fortunes were brewed by an old witch. Later numbers were passed with which the partners for supper were to be found. When every one was seated a most delicious supper was served. Following this Dr. McChesney and Professors Sloan and Allen told some of their inimitable ghost stories. The guests departed at a late hour, voting the annual Hallowe'en party a successful affair.

$$
\text { F. F. T. }
$$

\section{Y. M. AND Y. W. C. A. SOCIAL}

On Friday evening, September twenty-first, the Young Men's and Young Women's Christian Association entertained the new students at the home of Dr. and Mrs. Foster in Clifton.

The trip to Clifton was made in automobiles and, upon arriving, the guests were given a royal welcome. The evening was spent in "getting acquainted," and in due time dainty refreshments were served. The jolly crowd departed without seriously violating the ten o'clock rule. 

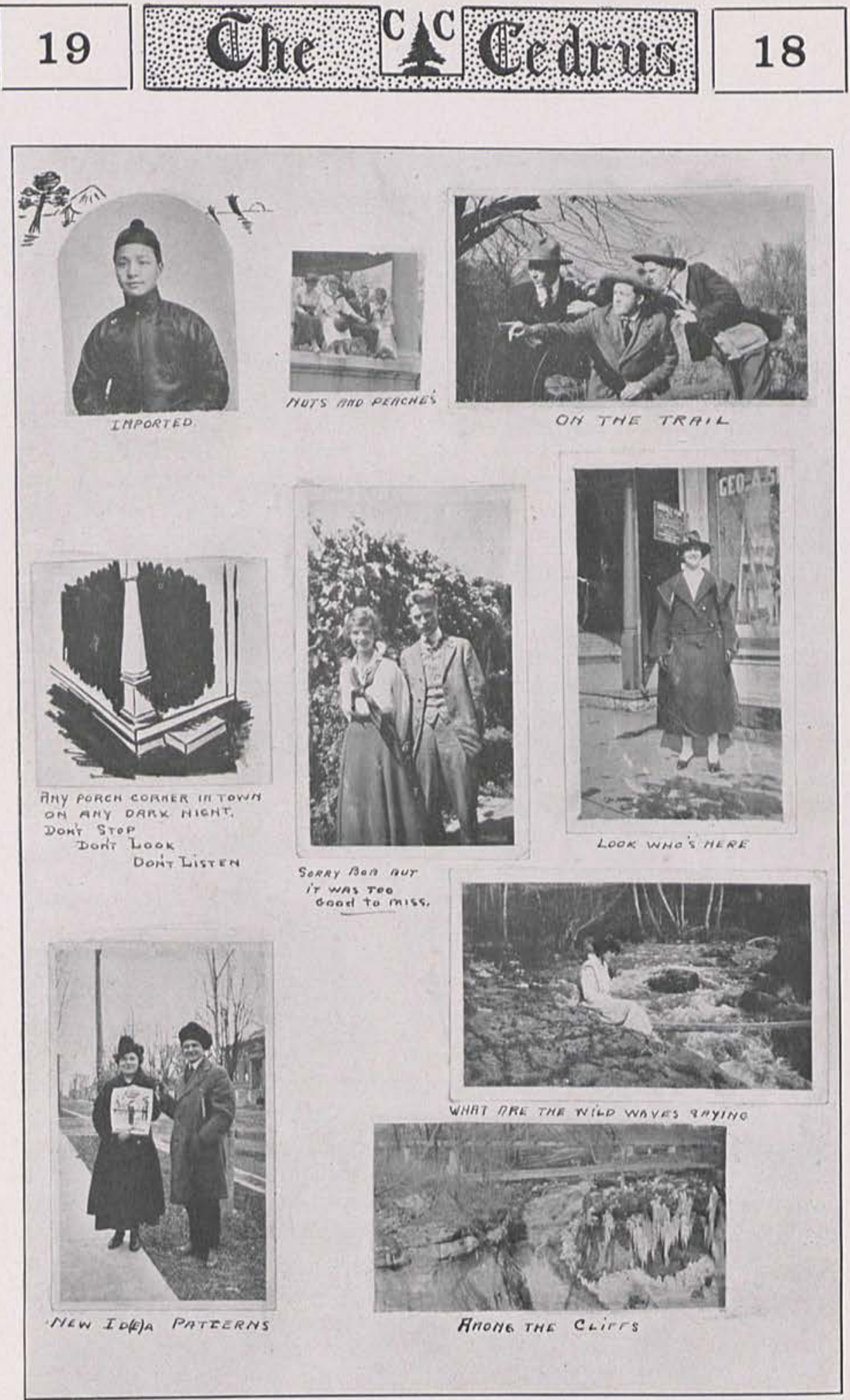

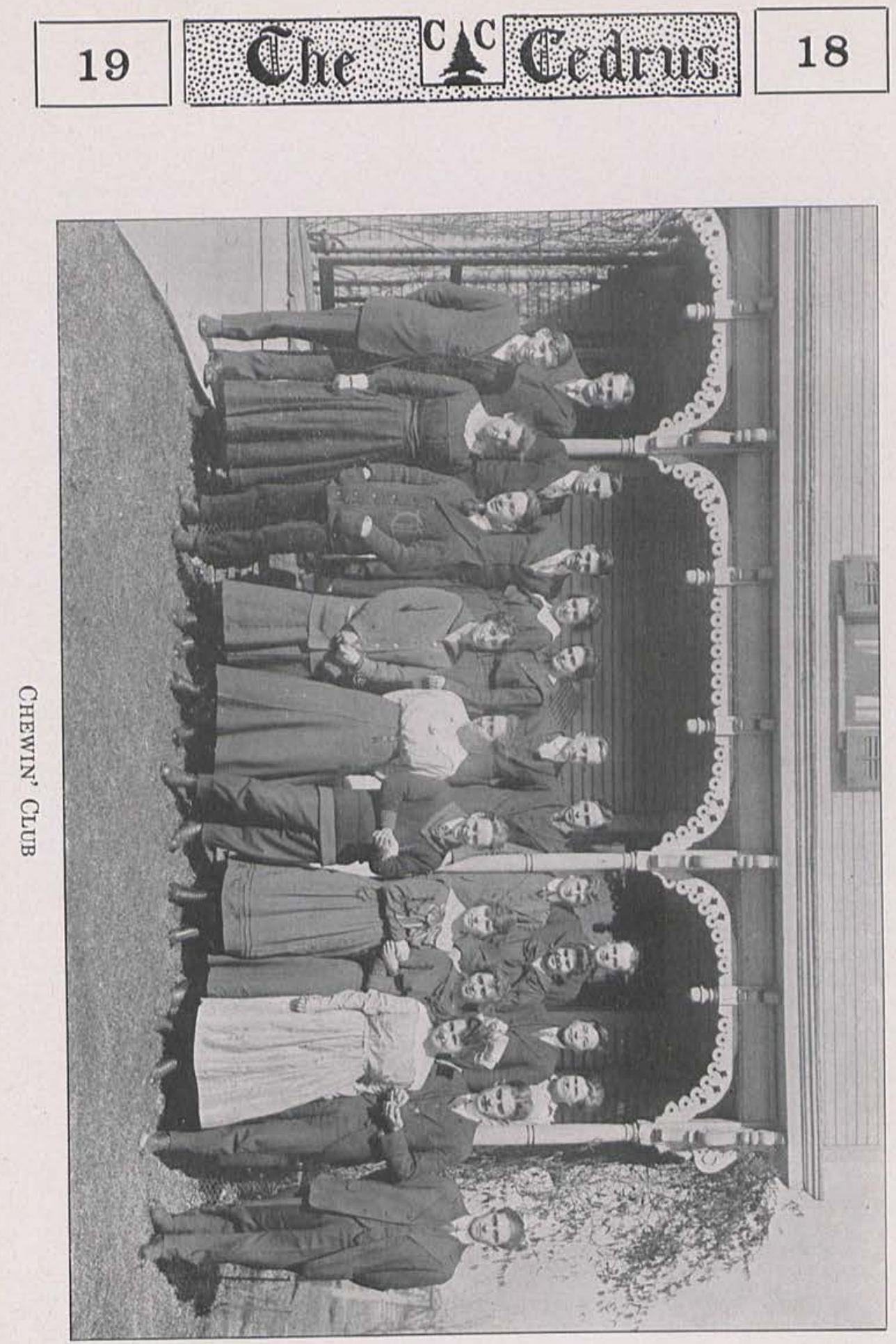


\section{9}

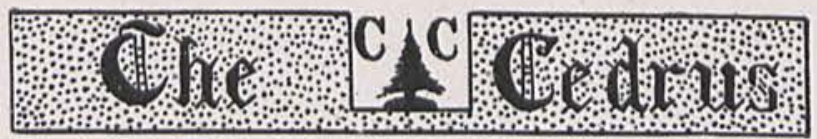

\section{WHEN THE VICTORY WAS WON}

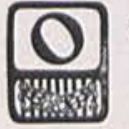

$\mathrm{N}$ a pleasant summer evening two lovers lingered along a country lane. The glimmering twilight invited sweet meditation, yet the two faces were sad. The girl broke a long silence.

"Must you really go in the morning, Bob dear?"

The young man pressed her hand silently.

"Pennsylvania will be empty without you," she continued, "and how your mother and father will miss you on the farm." She stopped suddenly and put both hands on his shoulders-"Oh Bob! how frightfully lonely it will be at our farm when you are not here to run in every evening." Tears filled her eyes as she spoke.

Robert Holsworth's own eyes were misty as he looked down at the girl. "Mary," he said quietly, "I'm going to fight for our country and for humanity, so we must be brave."

"I'll try to be" answered the girl, "but I do hate to think of you in the dangerous aviation service."

After a moment she slipped something into his hand. "Here is a little remembrance," she whispered.

Bob opened his hand and looked into the face of an exquisite miniature of his sweetheart. He could find no words, but his eyes were eloquent with love and gratitude as he drew her close in his arms.

Finally they turned toward Robert's home, where a little group of friends had come to bid him good-bye and Godspeed.

At the training camp at Fort Sam Houston, Texas, Bob made great progress. He was a natural mechanic and being quick to learn he soon surpassed the men in his own squadron. A month later he was transferred to a squadron that was about to leave for France. They were sent to Mineola and three days later embarked on a passenger steamer for England.

They went as first-class passengers and being the only soldiers on the ship were practically free from military routine on the way over.

One day Bob met a young lady whose appearance pleased him very much and later they were often seen together. She was a slender graceful girl with large brown eyes and dark hair. Bob soon learned that she was very fond of out of door sports, and in this her taste coincided with his. Her name was Frances Henderson and she was returning to France after graduating from an American college. As she explained to Bob, her parents, although American, had come to France when she was a child.

At last the ship reached its destination and the time came to part. Bob got everything ready to leave and then went to bid Frances good-bye. When the signal was given for him to fall in line she handed him a card on which her address was written. While Bob was crossing the gang-plank he attempted to put the card in his pocket but a gust of wind snatched it from his fingers and carried it away to the water below. It was too late to turn back so he went on feeling intensely disappointed. However, that night he wrote to Mary and he wondered at his own heart, as he thought of how near he had come to forgetting her. 


\section{9}

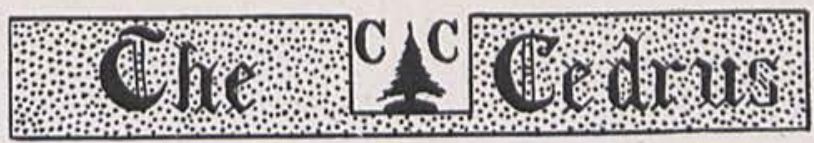

A few weeks later Robert Holsworth of the 102nd Aero Squadron of the American Expeditionary Forces in France distinguished himself in the art of flying so that he was given a machine of his own. His Commanding officer informed him that he must keep his machine out at least four hours a day and not more than six. He must make at least one landing other than on the camp grounds in order that he might learn to land on rough ground.

A few days later Bob ran out of gasoline and was compelled to land in a meadow about twenty-five miles from camp. He went to a near-by farm house and was delighted to find that the people were Americans. They were overjoyed to accommodate a soldier of the Stars and Stripes and invited him to dinner, which was just being served. As Bob entered the dining room he came face to face with Frances.

"Frances!"

"Bob!"

They exclaimed in one voice and the parents knew that their daughter's heart was not with the man whom they wished her to marry.

For the next three months Bob's machine could be seen landing almost any day in the same meadow. Sometimes he took dinner with the family; sometimes he stopped for a few words with Frances, but more often she went for a ride with him.

At first Bob's conscience hurt him a little. Was he being true to his sweetheart back home? But as time passed on that feeling gradually wore off. Was she true to him?

He had written to her many times but had not received a line from her. His mother had written to him that she had gone West. So the time came that he seldom thought of her.

While Bob was flying over the sunny meadows of France, Bob's mother went bravely about her work, but always with a prayer on her lips that the cruel war would stop and that her boy might return to her safely. Mary had gone to Colorado to keep house for an uncle whose wife had died suddenly. Her mother had received Bob's letters but for some reason they had all been lost and Mary did not even know Bob's address.

One day as Bob was coming in, his Commander told him that he would take charge of an instructor's machine. From now on as a result he was kept so busy that he did not succeed in seeing Frances for several weeks. His former machine was finally returned to him and was ordered to be ready to leave for the firing lines in forty-eight hours. At the first possible opportunity he went to see Frances. When he came in sight of the house he saw that there was a large gathering there.

Now Frances' parents were compelling her to marry a rich French business man. He was a dull, rather elderly man who cared for nothing but business and was marrying her because he thought it was cheaper than hiring a housekeeper. He was altogether an unsuitable companion for Frances, but his money attracted her mother.

Of this Frances had not told Bob, thinking that in some way she could prevail upon her parents to give up their project.

But the wedding day arrived with no relief in sight.

As Bob landed he saw Frances running toward him with outsretched arms. He also saw her mother start after her, then stop and walk slowly back to the house.

"Take me away; take me anywhere," sobbed Frances, falling into the young soldier's arms. Bob helped her into the machine, and as the aeroplane rose from the ground Frances told him everything.

"Take me to Aunt Emily's" she said. "She does not approve of the wedding and will help me." Realizing from what she said that this was the best plan of action, the young man throttled his engine to full speed, for the time set for his return to camp was fast approaching. 


\section{9}

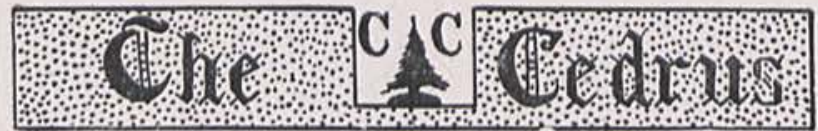

Bob entered the bunk-house that afternoon in a daze. He would not be allowed to leave camp again. What would become of Frances? He went to the bunk-house and began to pack his bag. Almost the first thing that his hands touched was a miniature. He looked at it with a start. Then he sat down and examined it tenderly. He felt as though he had been asleep and had just awakened. His thoughts flew back to the homeland. Where could Mary be? He had not written to her for two months and had not heard from her since he left Texas. How was his mother? He had not heard from her for six weeks.

Into his heart came a keen desire to be home again, even if it were for only a minute. The realization that Christmas day was just one week away intensified his homesick longing. Large tears came to his eyes and he buried his head in the blankets.

Presently he went to sleep and was awakened a half hour later by the friendly hand of his "Bunkey."

"Wake up, here," cried the genial lad. "See what I have for you. Of all the luck! Here is a letter from home and there is your Christmas box and here is a telegram."

Bob reached eagerly for the things and tore open the telegram with a nervous hand. It read as follows:

"Everything O. K. Aunt Emily telegraphed mother. Mother replied. Mr. Pierce married bridesmaid. Wedding over.-Frances."

Smiling a little at the astounding news in the telegram, he turned to the perusal of the message from his mother.

"Home, Nov. 10. 1918.

Dear Son-I have just finished the last pair of socks which I have been knitting : or your Christmas present, and will mail them today so that you will be sure to get them by Christmas. I am afraid that your Christmas will not be very happy this year, Robert, for I have some bad news for you. Mary has returned from the West snd she came over this morning to ask me to write to you for your letters never reached her, and she decided you had forgotten her. She became interested in a young western banker and was married a week ago. I know this will be a great shock to you but-" At this point he was suddenly interrupted by the frantic cheering of hundreds of voices. Running out, he saw the boys engaged in the wildest demonstrations of delight and triumph. He soon learned that they had just received a message that the Germans had dethroned the Kaiser and had set up a republican form of government, and had accepted Wilson's peace terms.

The war was over. Bob returned to his bunk and hid his face again, this time to weep for joy.

Ten weeks later on a bright, warm, Spring day, Bob Holsworth and his bride, whom he called Frances, arrived at his old home in the sunny hills of Pennsylvania. They were received with the greetings that only a mother can give who has waited, and watched and prayed.

LEROY H. CLARKE. 


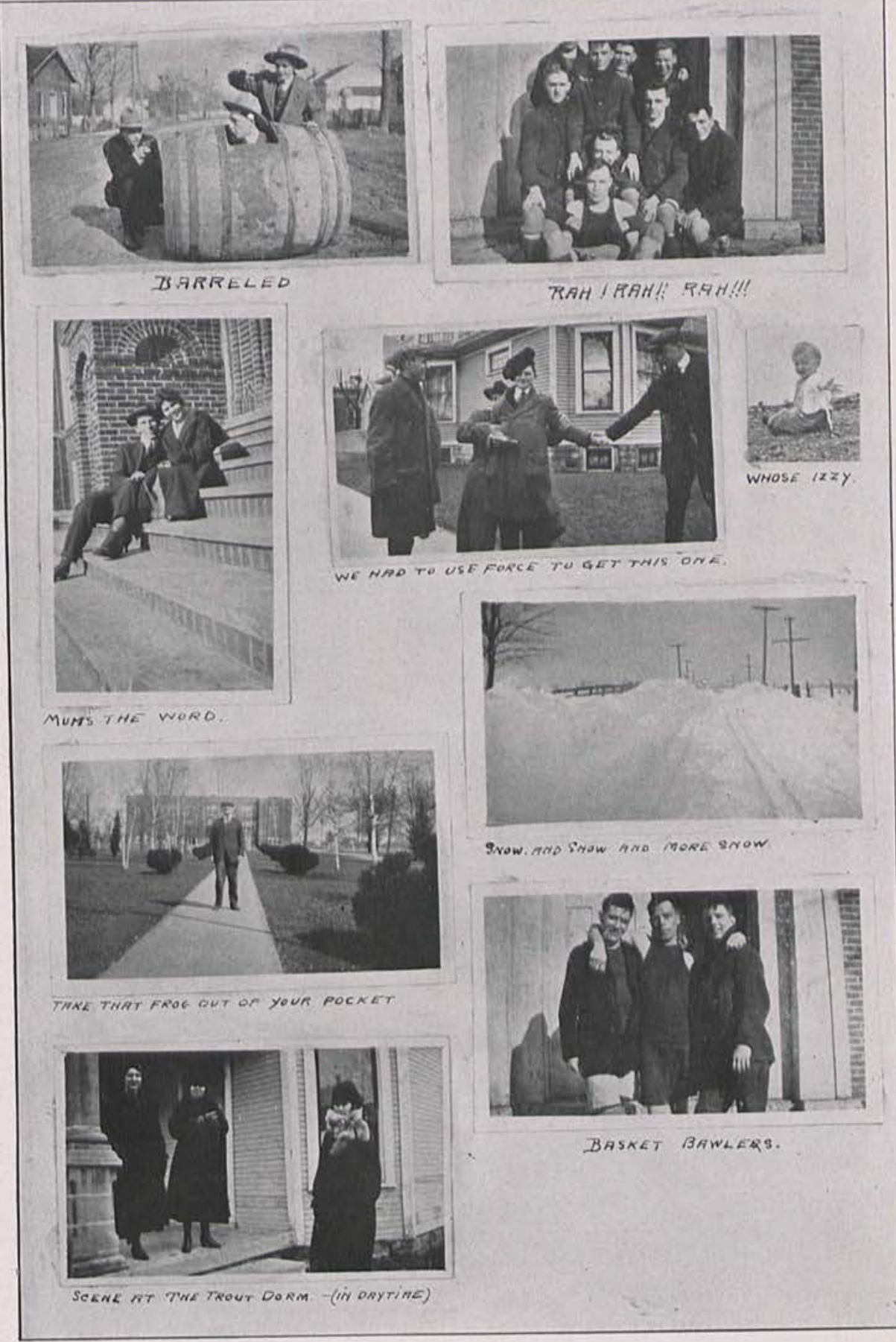




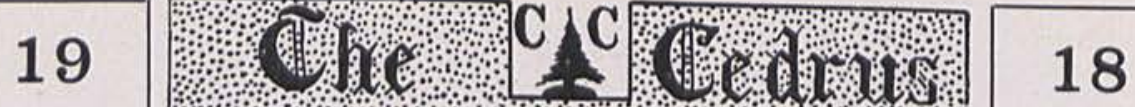

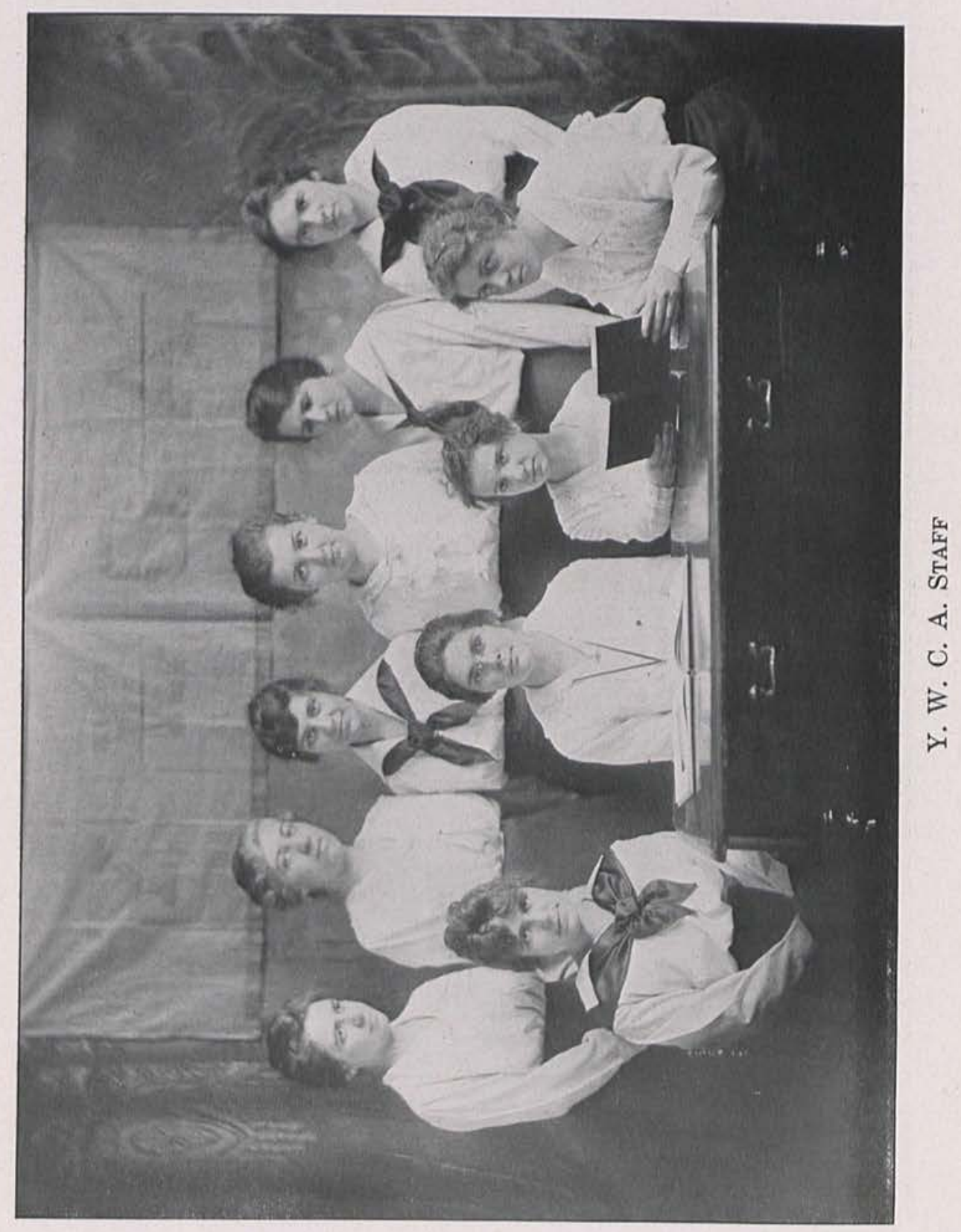




\section{9}

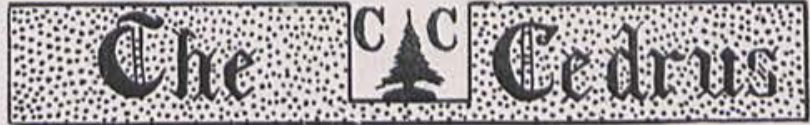

\section{HISTORY OF THE Y.W. G. A.}

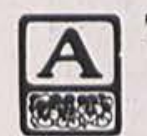

T the beginning of the year 1917-18, as usual the new girls were made to feel at home with a friendly word and a handshake from the Y. W. C. A. girls, whose aim it is to manifest a welcome and affectionate spirit to all.

After the opening meeting, the girls seemed desirous of belonging to the organization and this year we are glad to say that we have the largest per cent in our membership of the girls that we have had for several years. All of the girls have been very faithful in attending the regular Wednesday morning meetings which have been held in the Y. W. C. A. room in the college building.

Although time would not permit our girls to do a great deal for practical association work this year, they have indeed been very thoughtful for our nation in the time of need, and especially of our boys who are serving their country. In November the Y. W. joined the Y. M. C. A. in arranging for a joint meeting which was addressed by Rev. Mr. Macaulay, of Xenia, Ohio, who presented the object and the needs of the War Friendship Fund to which the girls contributed two hundred and fifty dollars. Cedarville College Y. W. C. A. is ever willing to do her bit, though it may be small. The basic principle of the Y. W. C. A. could not be stated better than by the words of the poet:

"Give strength, give tho'ts, give deeds, give self,

Give love, give tears, and give thyself;

Give, give, be always giving.

Who gives not is not living;

The more we give the more we live."

J. E. M. 


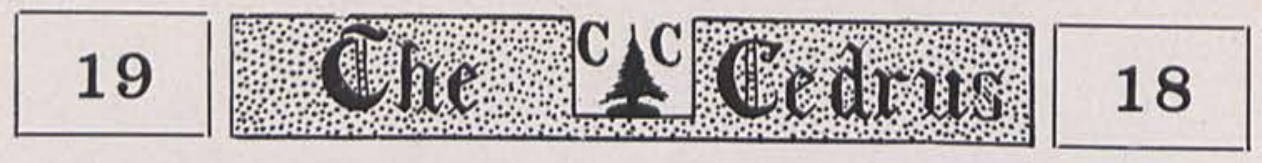

\section{HISTORY OF THE Y. M. C. A.}

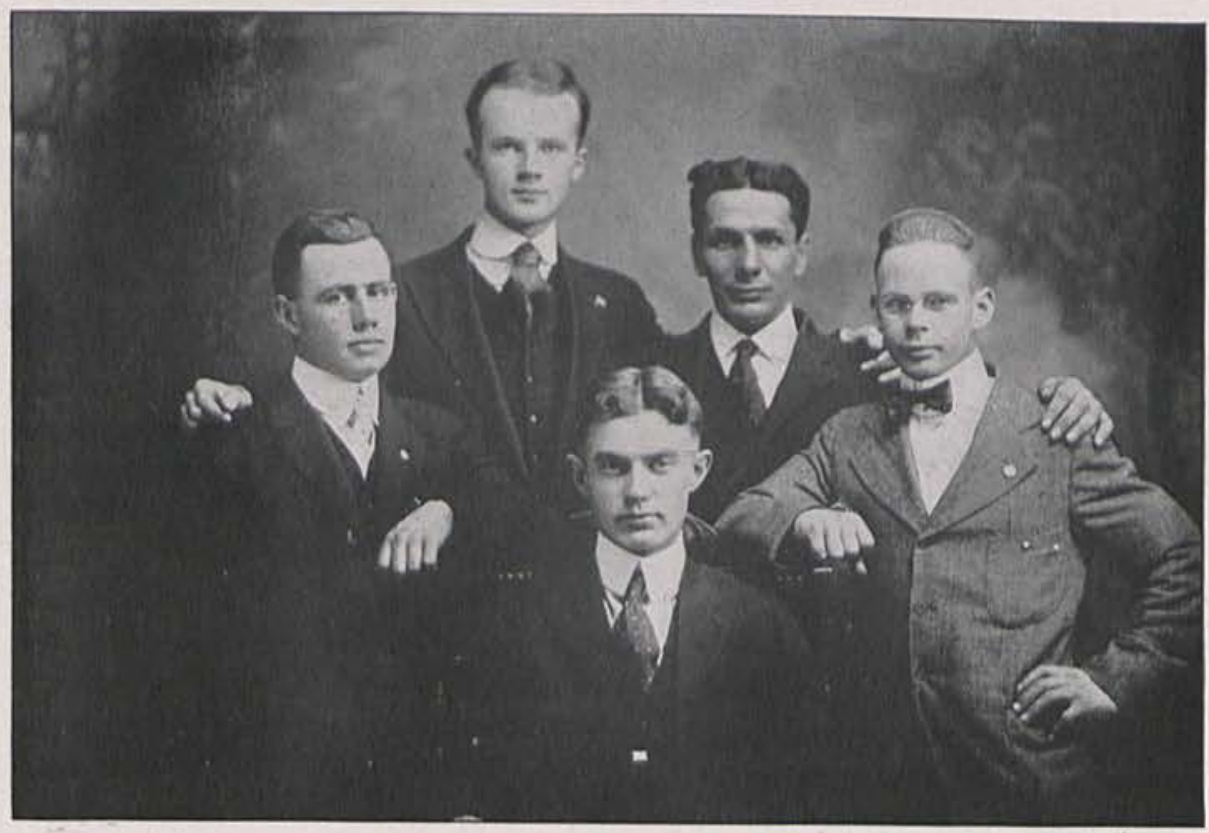

\section{Y. M. C. A. STAFF}

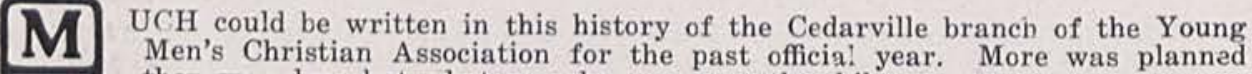
than was done but what was done was worth while.

There were a few social gatherings, but naturally, the great majority of the meetings were for the purpose of worshipping God and for discussing the vital problems of the Christian life. Members of the fac ulty often gave short instructive talks, and one meeting was held especially that the students might hear a lecture on Mexico by Professor Sloan.

Practically all the men in college are members of the association. The devotional meetings are always in charge of one of the members who brings up the subject for discussion after devotional exercises have been conducted. Each one does his part well and at one meeting it was remarked by Dr. McChesney that each one had offered at least a sentence prayer.

Robert Colman, our President, attended the Presidents' Conference at Otterbein. Our President also attended the convention at Columbus to promote the Students' Friendship Fund. The convention was attended by such noted men as Dr. John R. Mott, General Glenn and Governor Cox.

With the help of the cabinet, composed of officers and committee chairmen, plans were formed in the cabinet meetings for a Y. M. C. A. House. Two thousand dollars was pledged before the opening of the Fall semester. But the securing of a Y. M. Club House had to be postponed because of the increase in the price of materials required to fit up an ordinary building for such purposes. Besides, money should not be spent on anything unnecessary while people are starving. The students as a whole gave to war relief at different times. Together with the Y. W. C. A. the Y. M. gave over four hundred dollars to the Student Friendship Fund for the soldiers of the world to help them to be Christian men.

The President wishes mention to be made of the work of Meryl Stormont as Treasurer, and of Lawrence Kennon and William Collins as chairmen of committees and also as members taking part and doing more than their share to make the Y. M. C. A. practically helpful and valuable to all. We are sorry to lose them this year; but we are glad to feel that the world will not be sorry to have them.

P. J. E. 


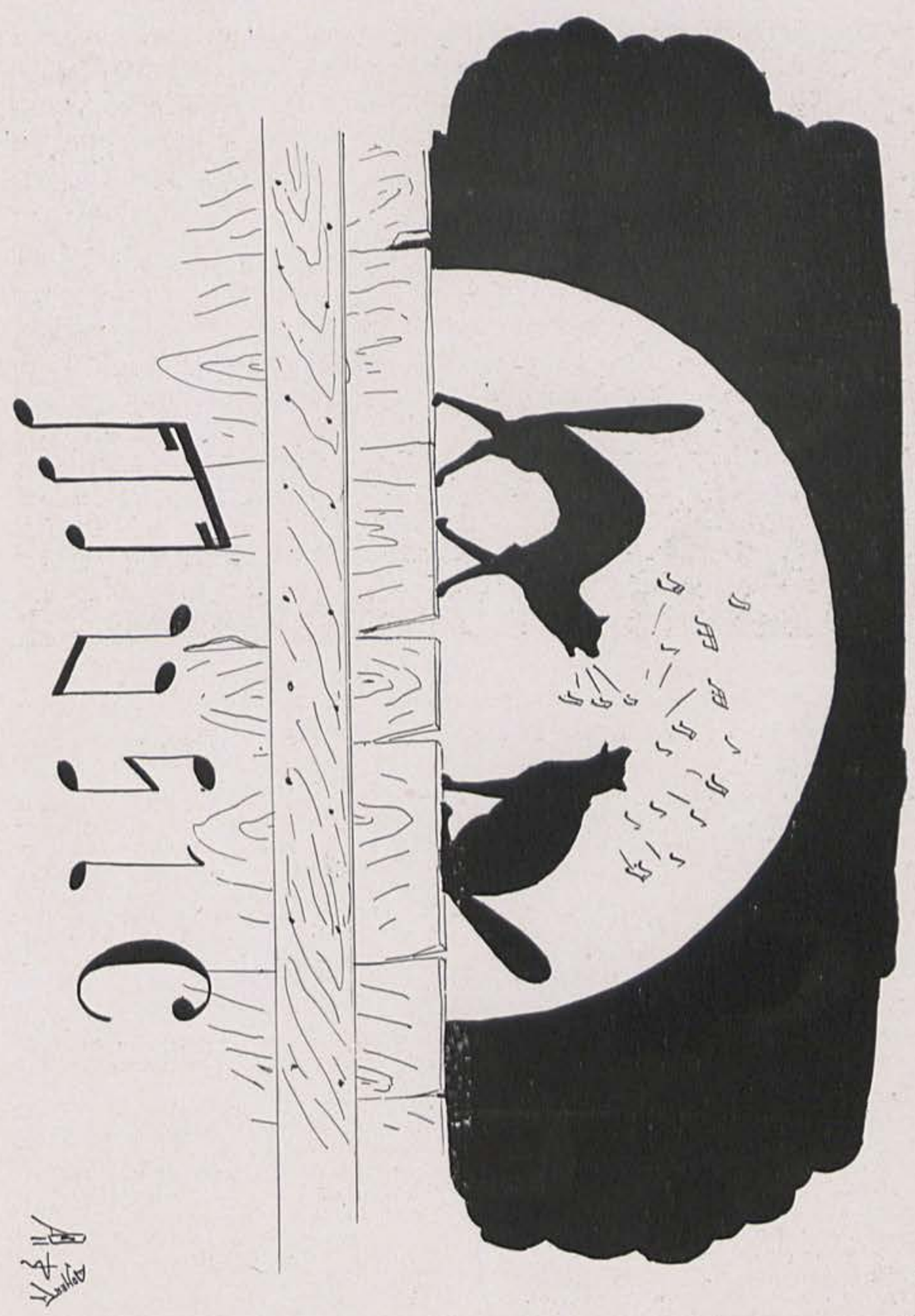



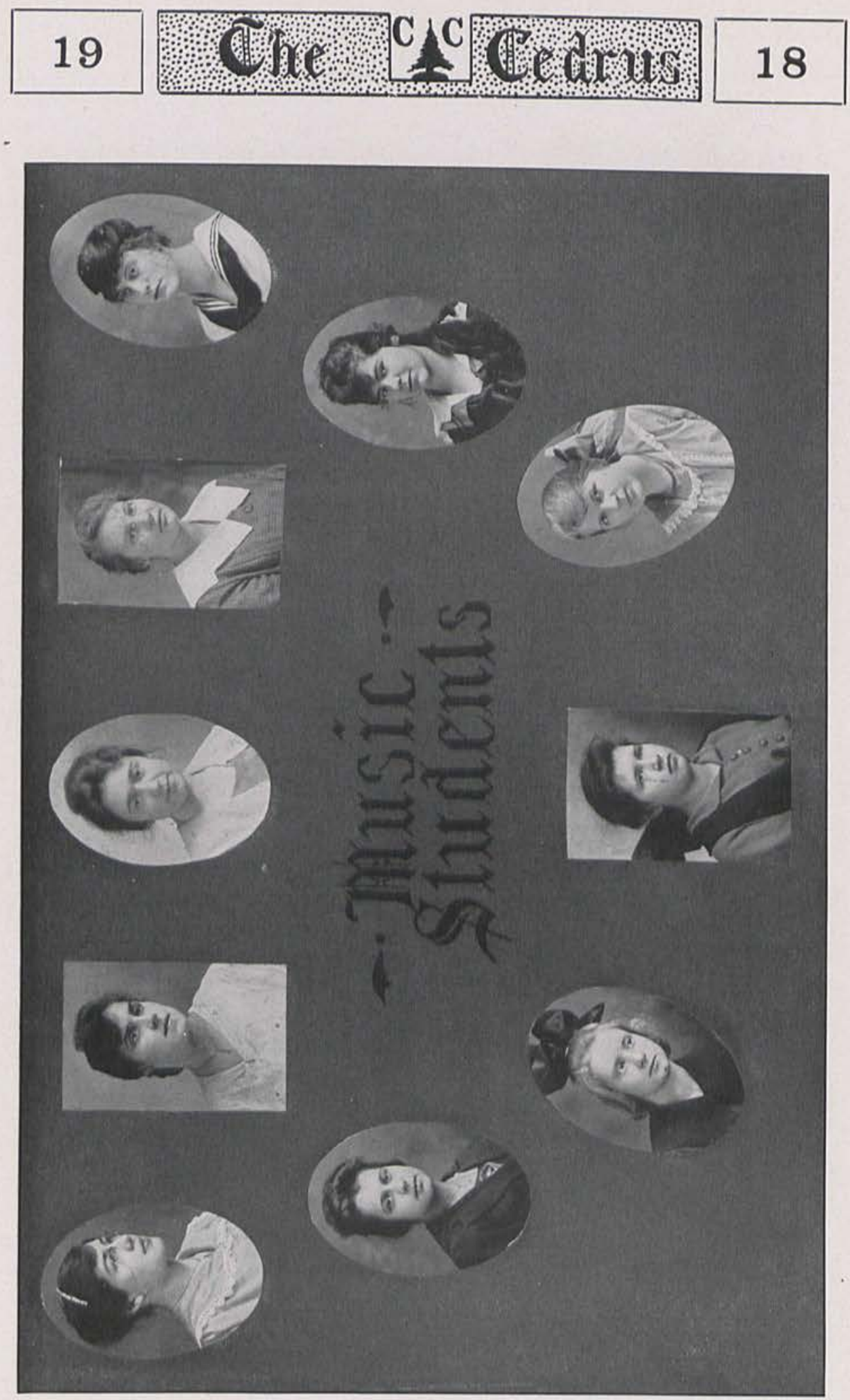

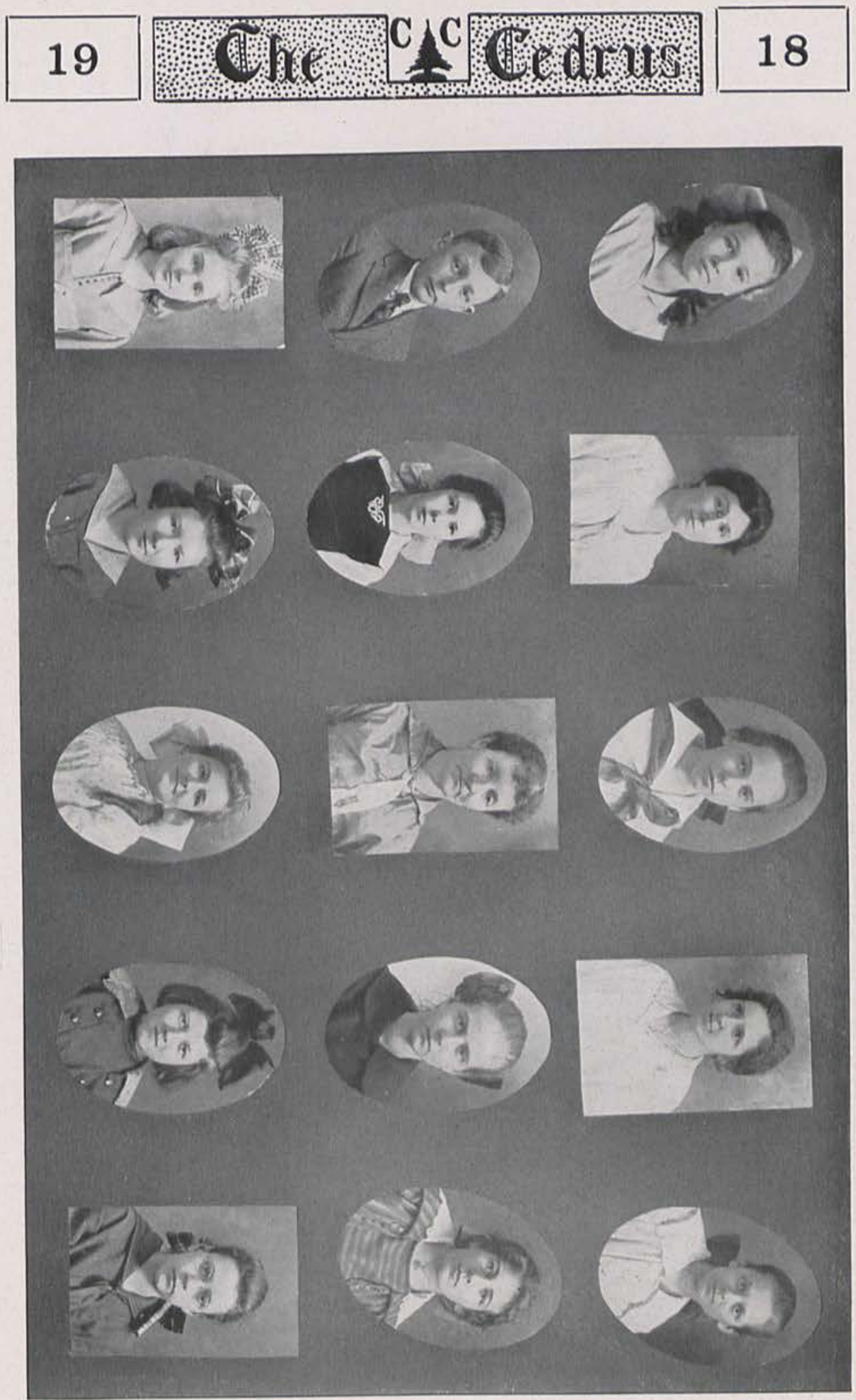

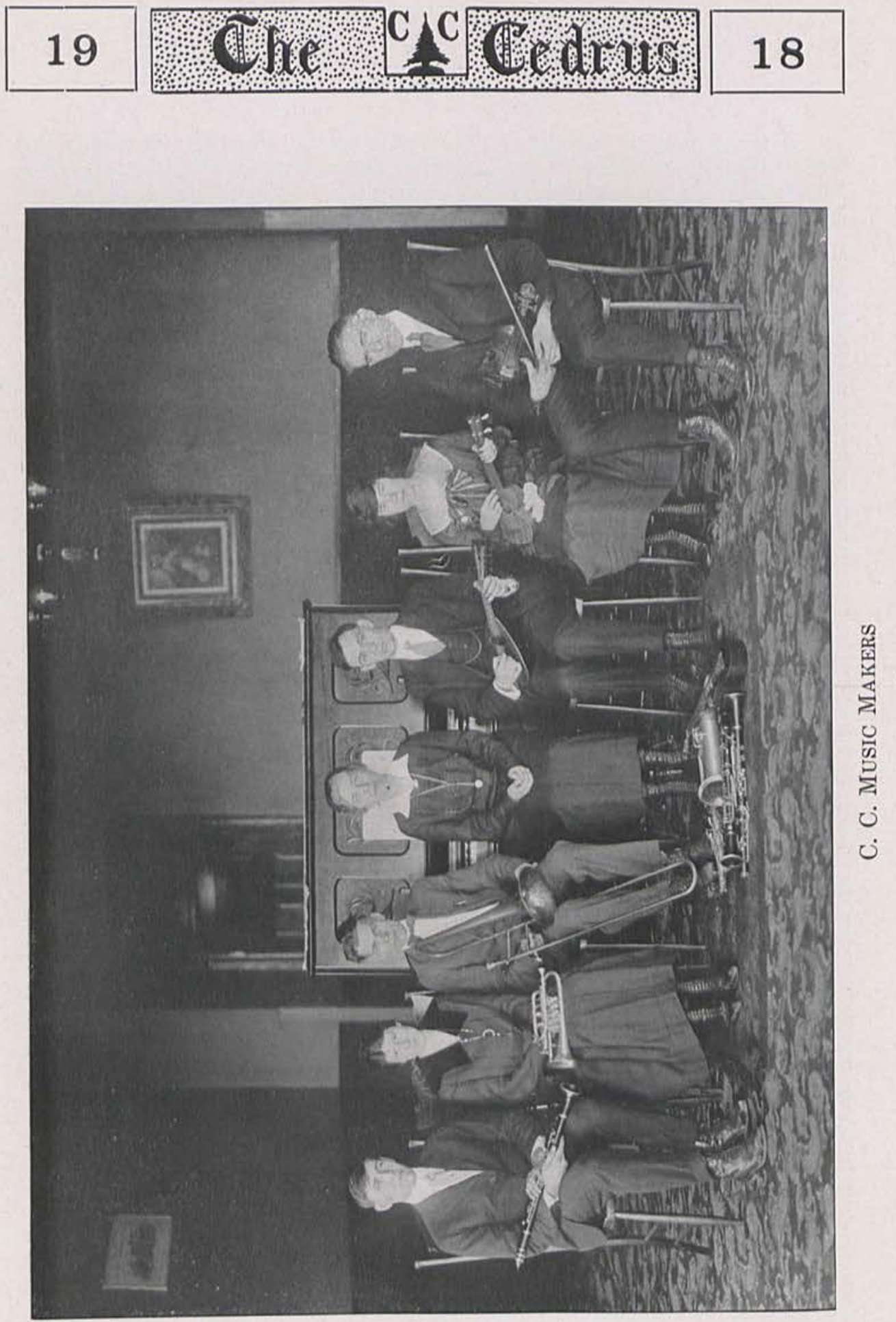


\title{
19
}

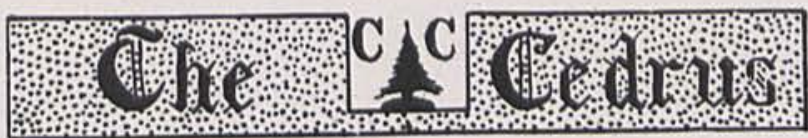

\section{FIFTY-FIFTY}

\author{
Listen, College friends-I was to tell what I could \\ Of the midnight trip of Paul Elwood. \\ On the thirteenth of February, nineteen hundred and eighteen, \\ The most notable night the College has seen.
}

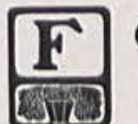

OR every question that arises in College life there are always two sides. This night was looked forward to by many. There was not a very large crowd invited although more really came than the hostesses were expecting. They came from all directions, in all ways and for all purposes. A part of this crowd went to the "Trout Dormitory" attired in their best, speaking properly, and very thankful to be the lucky ducks of the evening. A couple of young gentlemen even arrived there too early. Another group came to this "Dorm" slowly, disguised in costume, and since they were onlookers, they saw the event from a different standpoint and the after-image lasted longer than the same did for the other group.

After the young men had assembled and the wonderful surprise was accomplished, slowly the conversation dwindled away. Some few thought that they should go to the prayer meeting; others objected, holding the claim that they had ordered seats at the theater and that since their gentlemen friends really were there they had better take their limousine and sail to the theater on South Main Street. The butler was called and the car arrived. But it was filled with occupants. The passengers slowly alighted and managed to go in different directions around the house. In due time the invited group made their way to the restaurant while the other gentlemen were working and really enjoying themselves.

While this merry bunch of eight were enjoying "creamed onions" at Hinton's Restaurant, the Ministerial Relief Corps was viewing it from various angles. And later, while the crowd was endeavoring to enjoy the play entitled "The Man Hater," a group of gents entered the Bird home on Xenia Avenue, expecting to spend the evening with Paul Elwood. Much to their surprise, he was not there. As they left the room what should insist on going with them but his steamer trunk. Of course, they could not blankly refuse its company, so they kindly consented, showing it the way to its new residence. As they left the house the door was shut with a bang which awoke most of the dogs in the town.

Sad to relate, "The Dormitory" was safely guarded this evening, and try as they might, they made more noise than was of much good to them. Just as a lad was ascending a ladder, the top rung broke and as he hit the ground, the sentinel awoke and disbanded the crowd.

"Leaving the package on the front porch, we awaited their arrival. We dared not stay till morning, but departed in our various ways before the turn of the night."

About A. M. the trunk was seen wandering its way slowly homeward, never more to roam.

of all sad words in prose or verse,

The saddest are these-it might have been WORSE.

AN OLD OWL. 


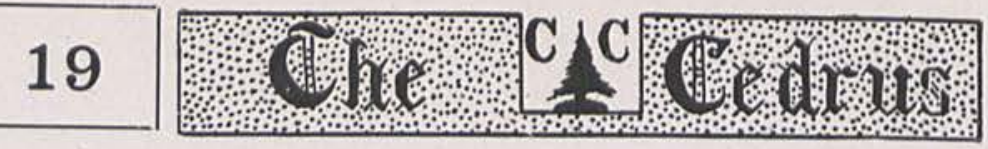

\section{8}

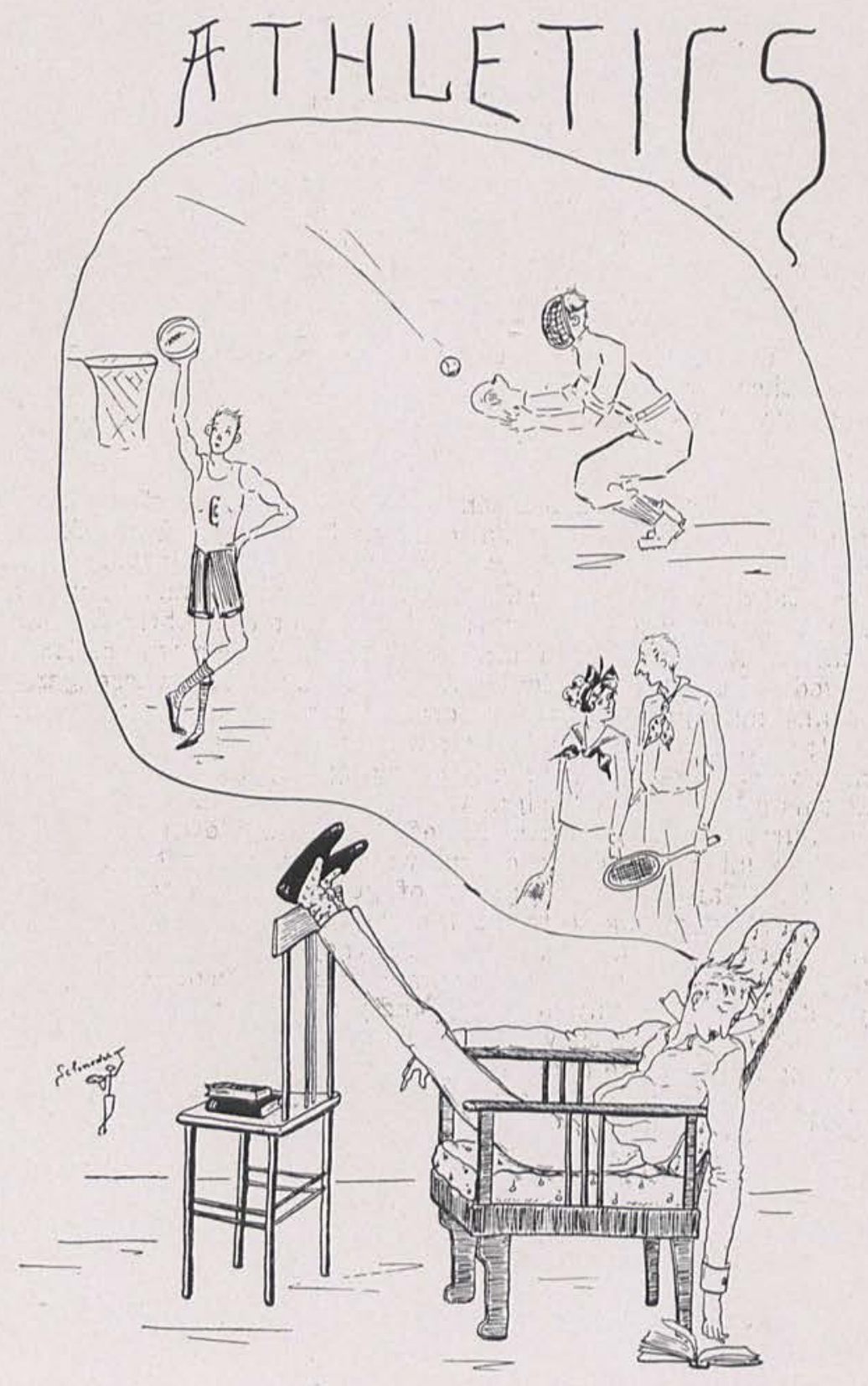




\section{C. BASKET BALL}

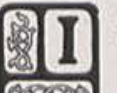

F the 1917-18 basketball season were to be judged by the number of games won and lost it would seem that it could scarcely be called a successful one. But, remember, there is another standard by which the C. C. basketball fans count success in the game. No doubt you are all acquainted with the fact that there are a number of colleges in the State of Ohio, but when it comes to basketball there are only two that really count in the minds of C. C. fans, Antioch and Wilmington. If a Cedarville College team succeeds in defeating these two teams in any kind of sport, be it basketball, baseball, or marbles then the season is counted a roaring success. Following out this line of reasoning you see the season just past was a roaring success of the first magnitude; for on February 15 our Quaker friends from Wilmington came to town with hopes high and expectations higher; but after forty minutes of real basketball they proceeded on their homeward journey with spirits low and their end of the score lower. We just evened up some old scores to the tune of forty-two to sixteen.

The season put in its appearance in November and departed this life on March 15. A six weeks' intermission on account of small-pox and Christmas vacation and another one of two weeks on account of vaccinated arms played havoc with practice and made it necessary to cancel three games.

The schedule consisting of fourteen games was completed in November but when small-pox, blizzards and other evidences of Fate had taken their several and respective shots at it, the aforementioned schedule had all of the appearances of having been run over by a British tank or had attempted to dispute the right of way with a German shell. It included in its theoretical stage two games each with Otterbein, Muskingum, Wilmington and Antioch Colleges, Columbus Deaf Mutes and DeGraff Independents, one game with Co. F, 330 Regiment from Camp Sherman and one with the Alumni. Three of these games, two with DeGraff and one with Wilmington were cancelled, leaving only eleven games of which three were won and eight lost. But then, small-pox makes a good goat so why not give it all of the blame and say no more about excuses.

Early in November practice was begun; "Ollie" Cornwell was chosen Captain and a squad of seven men were picked for the team. These seven were as follows: Cornwell, R. Collins, Creswell, Kennon, W. Collins, Thorn and Chesnut. Chesnut was unable to finish the season but Wright filled his place in splendid fashion.

Kennon, our mainstay at guard received a broken nose as his share in the spoils of the Wilmington game, thus being kept out of the game until the last game on March fifteenth.

The regular line-up during the season was:

Cornwell-Center; R. Collins-Left Forward; Thorn-Right Guard; Wright-Forward; Kannon-Left Guard; Creswell-Right Guard; Chesnut-Forward; W. CollinsRight Forward.
- W. R. C. 

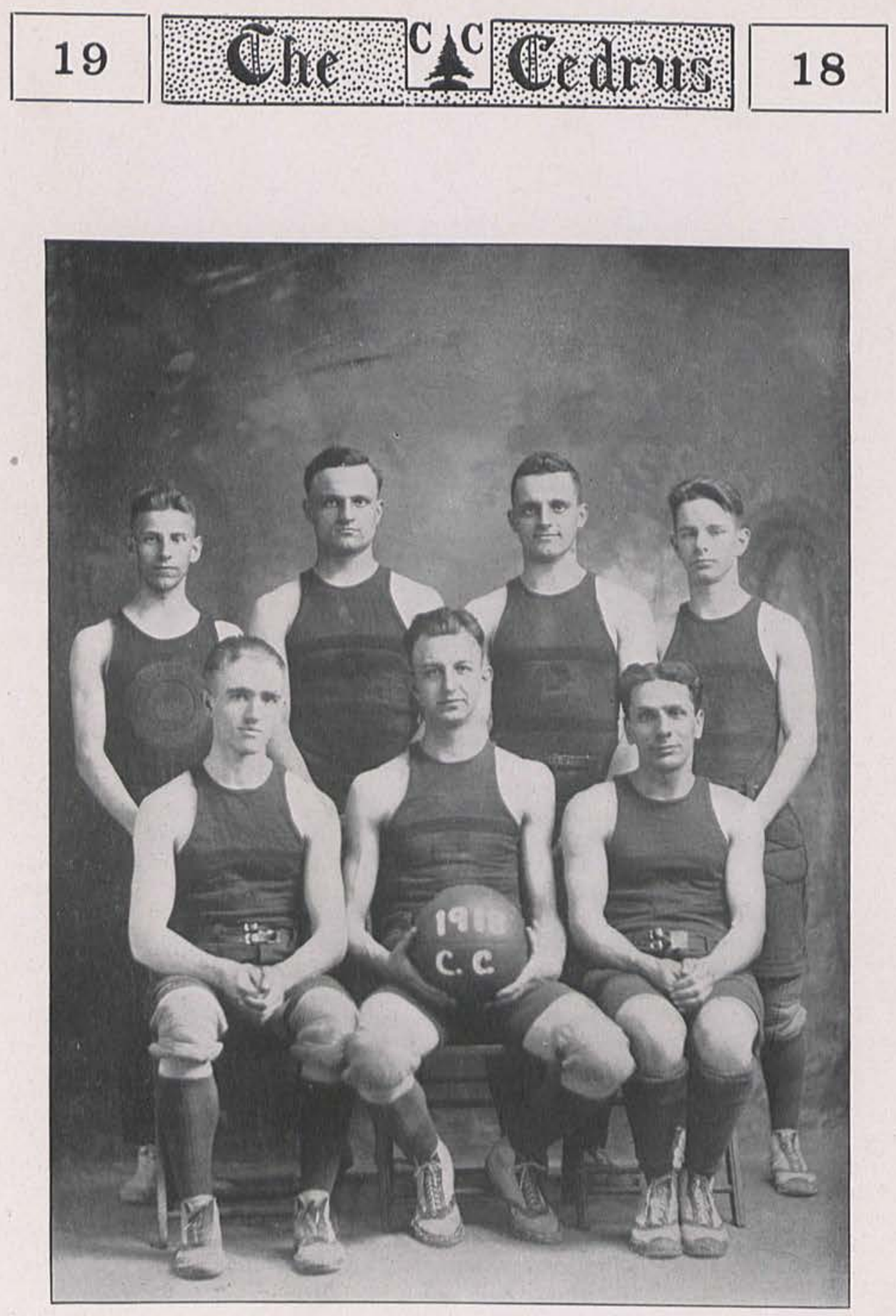

Basketball TEAm 


\section{9}

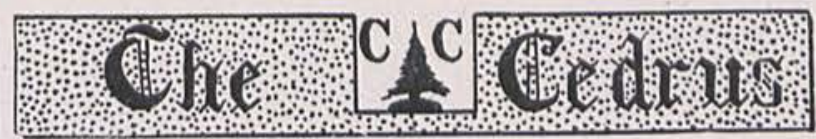

18

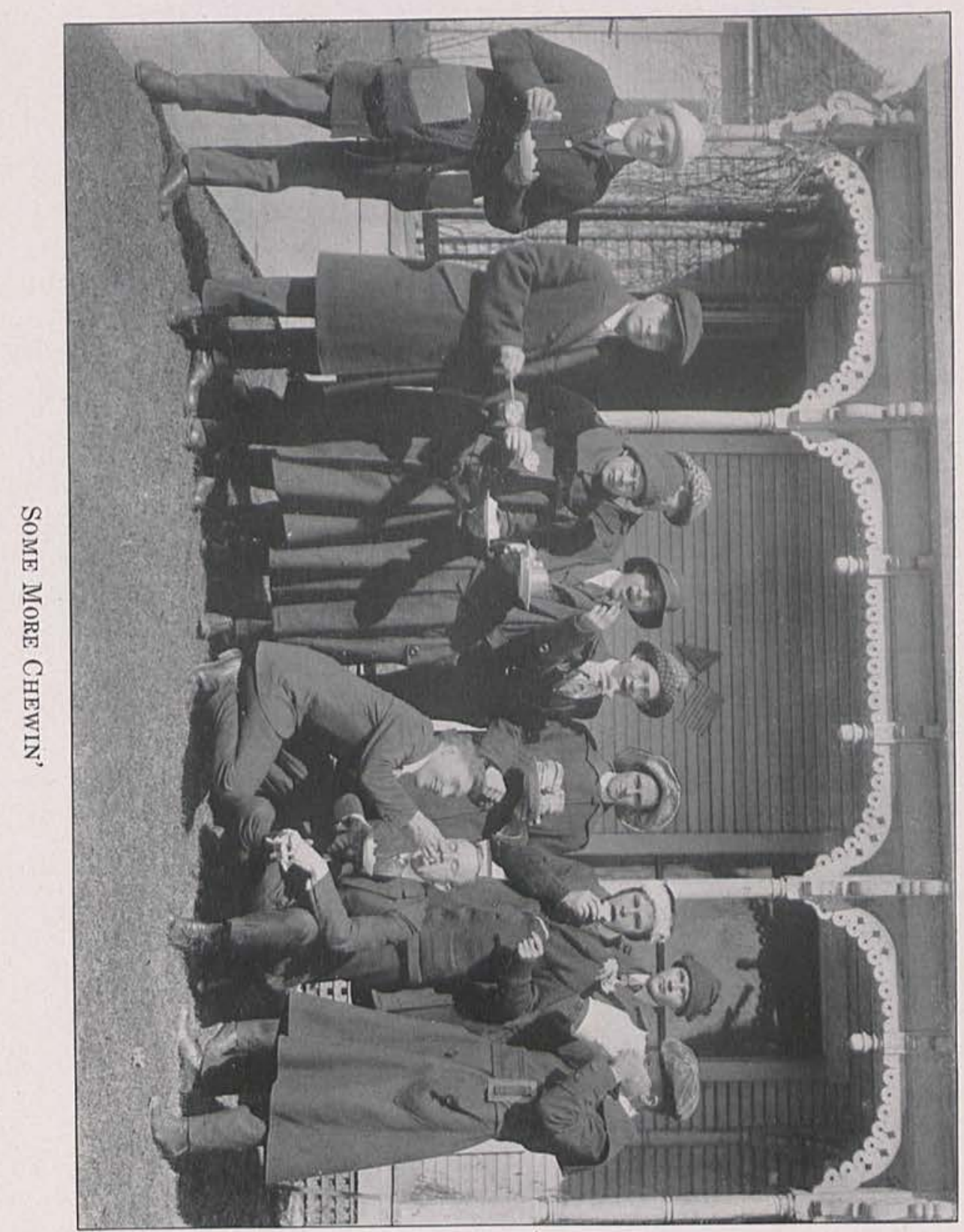




\section{9}

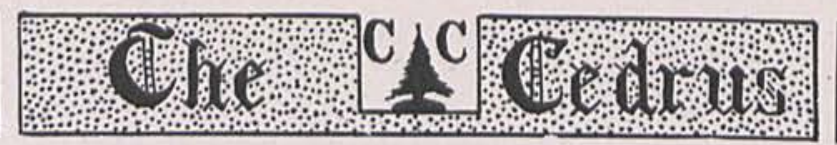

\section{OUR KHAKI-CLAD ALUMNI}

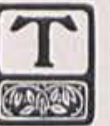

HAT C. C. is justly proud of her alumni is becoming a proverbial phrase in the college circles. When we find that Uncle Sam, too, is proud to claim them as his loyal subjects, as is evidenced by the rank and titles of those of our number who have donned the national uniform, we see that our Alma Mater has ample reason for self-gratulation.

Twelve of our number, at present writing, are now in cantonments somewhere in America, and are preparing for "o'er seas" service. They are: J. Cecil George, '01; Homer Henderson, '02; W. R. Graham, '05; Fred Bird, '10; Hugh Turnbull, '12; Wendell Foster, '13; Cameron Ross, '15; Cecil Burns, '15; David Bradfute, '16 ; John Collins, '17.

If Kaiser Bill knew that Cedarville College was furnishing such men of brawn for the war-path, he would undoubtedly make a flying trip here in a mighty Zeppelin to render the institution a bleak and shattered memory.

Prussian militarism must be crushed! And far be it from the alumni to regard lightly this very great and precious privilege of being represented in this noble struggle for world-wide Democracy and Peace.

M. E. B. 


\section{9}
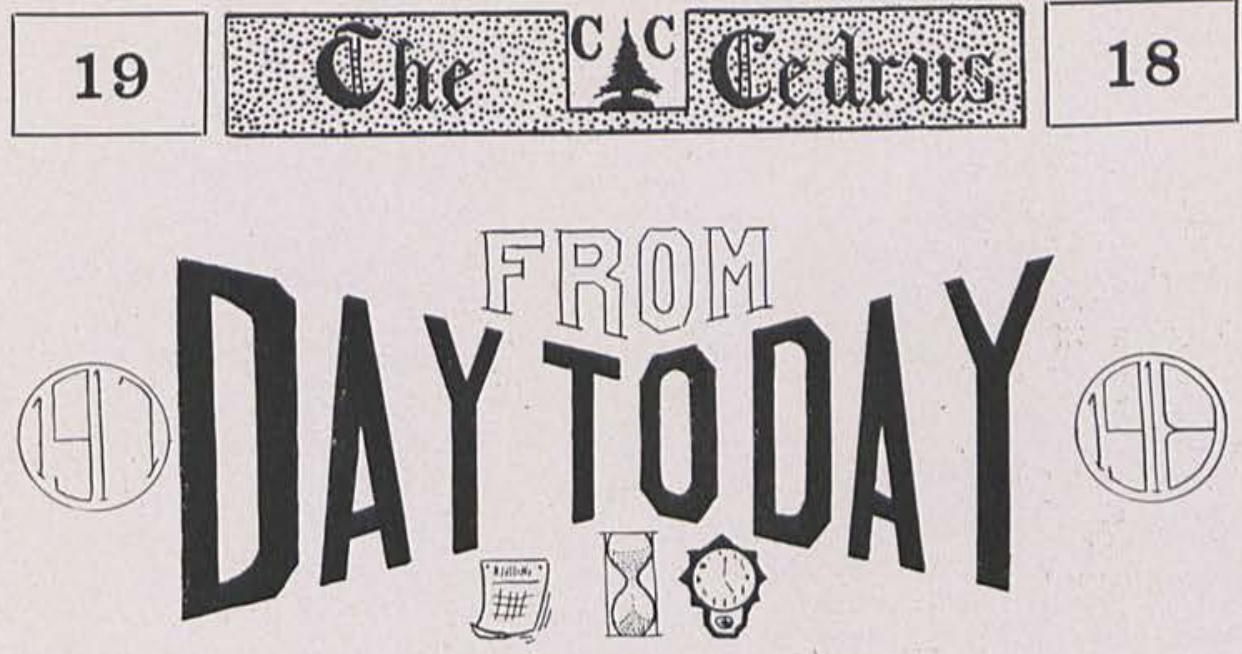

\section{THE CALENDAR}

SEPTEMBer 12. Opening address by Rev. Dr. Rourke, "What is the Value of Your Life?" Everybody glad to see everybody else.

SEPTEMBER 13. Becoming adjusted to classes. Some job for the Freshies.

SEPTEMBER 14. College students and Faculty entertained by the R. P. C. E. Society.

SEPTEMBER 17. No school on account of the funeral of Professor Morton.

SEPTEMBER 18. Tennis playing is the order of the day.

SEPTEMBER 19. Rain! Rain! Rain!

SEPTEMBER 20. Everything quiet along Massie's Creek.

SePtember 21. Y. M. C. A. and Y. W. C. A. entertained at Rev. H. C. Foster's for the faculty and students. Some fine time. Some left. Others mated.

SEPTEMBER 24. Fixed seats, after this in Chapel. Ellen says, "I'm fortysix."

SEPTEMBER 25. Soph-o-mores, after having been thoroughly frightened by an innocent Jun-ior, hold a spread.

SEPTEMBER 26. Clubites get merry dinner but spirits are dampened in the evening. It rained.

SEPTEMBER 27. One girl has two appointments, but-decides for Thorn.

SePtember 30. Blue Monday. No lessons.

OCTOBER 1. Two or three Freshies? Oh, so homesick.

OCTOBER 2. Everybody's doing it. What? Studying.

OCTOBER 3. Miss Gilkey informs the Gen. Method class she'd rather make a bridal gown than an apron.

ОстовеR 4. Prof. Allen requests his class in debating not to talk about their subjects for debate at the Club. He says the Club members don't think deeply.

OCTOBER 5. Nothin' doin' tonight; only a select few at Bill Anderson's.

OCTOBER 9. Two couples get apple-hungry; walk out to the country and carry back a half-bushel of apples.

OCTOBER 9. Cold and stormy.

OCTOBER 15. First number of the Lecture Course. Also the unsuccessful "belling" of Mr. and Mrs. Wisecup, newlyweds.

OCTOBer 16. Rev. Mr. McGaw spoke in Chapel.

OCTOBER 17. Temperance meeting at the Opera House. Everyone invited.

OCTOBER 18. Orange and Blue Literary Society organized. 
OCTOBER 19. First snow of the season.

OCTOEER 22. Everything and everybody out of sorts.

OCTовеR 23. Weather turned around. We've been having March in October.

ОСтовеR 26. Girls entertain boys at Hallowe'en party at Miss Creswell's. Some time finding the place. "Oh, those ghosts!" Various members of the Faculty told exciting but true ghost stories.

OCтовеR 30. Listen! Orange and Blue had their first meeting. And so did some one else. Cedarville Herald said that it was great.

NOVEmBER 2. Another temperance meeting at Opera House in charge of the Cedarville Public Schools.

November 6. Election Day. Ohio Dry. Beautiful Day.

November 7. Did you see the morning paper? Yes, it's wet. No, it isn't. Yes, Cincinnati found a lot of votes. Isn't that a shame?

November 10. Greeted our first foreign student, Walter C. T. Chu.

NOVEMBER 13. Yes, two weeks are up. Another meeting of the Orange and Blue. Prof. Allen ran out of words in describing the productions.

NOVEMBER 16. Oh! For a spread!

NOVEmber 20. Second Lecture Course number, "Bought and Paid For." Several new and astonishing couples.

November 21. Alumni basketball game. Boys successful. Girls Proceeds for Y. M. C. A.

November 22. An eventful day. Dr. Marsh announced smallpox in college. Some sad bunch.

About 8:30 their exclamations changed, for they were going home.

JANUARY 1. Students began coming back. Trains all late. But a Happy New Year to you all.

JANUARY 2. College opened, everybody glad to get back and have our ranks unbroken. Students still straggling in.

JANUARY 3. Professor Bauman applies his biological knowledge to macaroni.

JANUARY 4. Rumor-College closed again on account of smallpox. All glad was false report.

JANUARY 5. Tears shed for Hannah. But another soldier is happy.

JANUARY 7. Third number of lecture course.

JANUARY 8. Several students attend prayer meeting at U. P. Church in observance of week of prayer.

JANUARY 11. Several of the students went home, and started to return Sabbath evening or Monday morning, but "best laid plans of mice and men gang aft aglee," and-

JANUARY 14 . Was bitter cold and deep snow so the trains could not come through.

JANUARY 15. Still more snow, 14 inches on now. At $10 \mathrm{p}$. m., the poor stragglers reached home.

JANUARY 16." "Please don't touch my arm." "Yes, I think it is going to take." "Oh, I forgot you were vaccinated."

JANUARY 17. Prof. Sloan prays for our "arms" in Chapel.

JANUARY 18. Prof. Allen explains Connotation by calling Mr. Rickenbach, Mr. Gilkey. An apt illustration.

JANUARY 21. Debate class is given several beauty hints.

JANUARY 22. Honor roll of those vaccinated read in chapel. Some honor. 
JANUARY 23. Snow. Snow. Snow. Quite a number of frozen ears.

JANUARY 30. Biology Class has second test. Somewhat shorter than the first. Still room for improvement.

JANUARY 31. Last day of semester. Every one glad. Oh! Did I make 90 ? I wonder.

February 5. New semester. Some disappointment over grades. Rev. Mr. Patton made opening address. Rev. Mr. Benson, from Kansas, made a few remarks.

FEBRUARY 6. Every one determined to make a better grade this time. Antioch beaten, 48-21.

FEBRUARY 8. Sorrow deep and sincere, for one of our dearest friends has been called home.

February 11. Spring seems to be here. Heavy coats are laid aside. Just a tempter.

FEBRUARY 13. Dorothy Smithson thoroughly surprised. Quite a fine time and oh, you eats!

February 14. Well, did you ever? At last our dear little Freshies have had a spread. We are so glad, even tho some of the upper classmates were "canned."

February 15. Day of prayer for colleges. Rev. Mr. Dodds, from Xenia, delivered a splendid address on "Character."

FEBRUARY 18. Hurrah for our Faculty Adviser. We each have one, you know. Prof. Bauman delivers lecture on "Evolution."

February 19. Rain, Rain, Rain. Prof. Bauman gives his Biology Class a lesson in drawing.

February 21. A little colder. Party at Miss Ellen Tarbox's. Everybody had a good time.

"Let us then be up and doing,

With a heart for any fate;

Still achieving, still pursuing,

Learn to labor and to wait."

FEBRUARY 22. Vacation time. Thanks to Washington.

FEBRUARY 25. Announcement for Cedar Stunt to be prepared. Ralph Elder leads in chapel.

FEBRUARY 26. Wheeler took group pictures. Lowell-Longfellow program rendered by Literary Club. Ramsey girls have always said that they liked the hills. We believe it, for they enjoy walking with the $\mathrm{Pa}$. boys.

February 27. Humorist on lecture course. Paul Duncan has another girl! FEBRUARY 28. Feb. gone. Good-bye, old scout!

MARCH 1. Antioch vs. Cedarville College. Antioch successful.

MARCH 4. Oh, you Spanish test! 'Fess up, "for the very hairs of your head are numbered."

C. H. S. presents picture at Murdock Theater for Y. M. C. A. work.

MARCH 5. Spring fever is prevalent. Rev. J. M. Colman lectures in chapel. Prof. Bauman called for physical examination.

MARCH 6. Cartoonists at work on Bulletin Board.

MARCH 7. Service flag dedicated in honor of our brave boys. Twenty stars are shining on the flag for Cedarville College.

Letters were read from P. H. Creswell, one of C. C.'s boys in Italy.

MARCH 8. "Spanish class must either hang together or hang separate." Rev. Mr. Colman delivers lecture in chapel. 


\section{9}

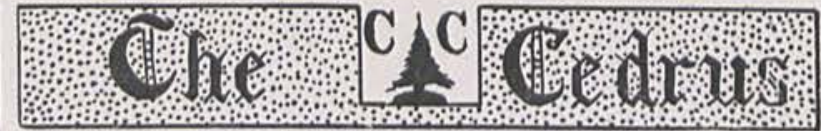

MARCH 11. Windstorm took the roof off the Gym. Work is resumed in Biology Lab.

MARCH 12. Lecture by A. C. Latimer, "Mysteries and Secrets of the Mormon Religion."

MARCH 13. "The rain it raineth every day,

On the just and unjust fellow,

But more upon the just than the unjust,

For the unjust had the just's umbrella."

MARCH 14. Last number of Lecture Course. Fairchild Sisters Quartette. "A friend in need is a friend indeed." "Oh! did you find my Lecture Course ticket?"

MARCH 15. Paul Elwood leads chapel. Afternoon classes disturbed by a bucket rolling down the stairs.

MARCH 18. The Gym is being prepared. Basketball season is over. Supper delayed at the Club for sake of baseball practice.

MARCH 19. Orange and Blue program. $\$ 1,000$ offered as reward to any one who will persuade Harold Hammond to have more than two dates with the same girl.

MARCH 21. Measles are in order. Rickenbach and Foster clash—not serious. Rickenbach victorious.

MARCH 22. Student body and faculty entertained at the home of the President. Bob Colman has a good sleep in the P. M. Several of the boys went out sight-seeing. Caught Nelson Thorn taking piano lessons.

MARCH 25. Test in History first hour, Debate second hour, Ethics third hour, Biology fourth hour. Since there were only four recitation hours, we concluded that there was a test given every hour.

MARCH 26. A most notable day. Freshman, Senior and Junior Classes have meetings. A most delightful time and also delightful chicken. A day long to be remembered.

MARCH 27. Remnants of chicken roast found in various places.

MARCH 29. Very interesting topics in extempo. Clark talks on chicken roasts. Hammond on monkeys.

APRIL 1. Students fooled the professors by being here on time, even though they did adopt the new time.

APrIL 3. A great big feed at the G. H. Creswell home. What did we have to eat? Chicken, wieners, cakes, bananas, pickles, sandwiches, etc. "Have a heart! Don't throw that light in our face!"

APRIL 4. Prof. Allen calls for volunteers in the P. M.

APRIL 8. Famous debate, nothing at the beginning, nothing at the end, and nothing between, yet the speaker won the debate. For his opponent had only a few blank cartridges.

APRIL 15. Splendid illustrated lecture, "America, Wake Up!" Word received that Carl Duncan was first of our boys to receive a wound.

APRIL 18. Senior Class meeting on the College steps. They are getting to be some bunch. Some leave early. We wonder why? Two foreigners were present at meeting. Prof. Bauman and Paul Elwood, a Sophomore.

APRIL 19. College received two splendid gifts for endowment, in form of Liberty Bonds. 


\section{9}

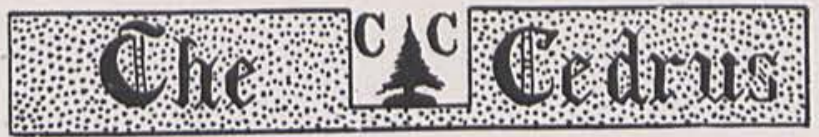

\section{OUR SITUATION}

Once upon an evening dreary,

I was wrestling, weak and weary,

With some Cedremetric problems

I had never seen before;

Problems that all toil resisted,

Though I gropingly insisted,

With all my mental powers enlisted,

As I never had of yore;

But the problems all unraveled,

Lay there calmly as before-

Only this and nothing more!

Quite distinctly I remember, It was in the bleak December,

When I was a humble member

Of the Cedrus staff of yore;

Eagerly I wished the morrow

When I hoped that I might borrow

Explanations from a staff-mate

Who had helped me out before;

Who had loaned me his assistance,

When in swampy paths before;

"Yes," I whispered, "just once more."
Long I sat there, madly yearning, All my soul within me burning,

Longing, thinking things no students Ever dared to think before;

"Oh, begone all situation

How I wished my education, And the hours of presentation Were a memory of yore!

How I longed to look back thinking They will bother me no moreFree from care forevermore."

But the months in their rotation Finished Cedrus publication, And the longed-for presentation Is a thing to come no more, But I find I now am vexing O'er situations as perplexing As the ones, I on that evening Fought of Cedremetric lore; Just as stubborn and inflexing As of Cedremetric lore, Trouble me forevermore!

When our tasks are thus repleted

And the situation well completed

When we are no longer gathered

In the staff-room as before,

Now our Cedrus is before us

And we wait for approbation,

For 'tis not till life is over;

And our spirit from its burdens,

And its tasks as days of yore,

Shall be lifted evermore!

(With apologies to Poe. L. O. S.) 
REFORMED PRESBYTERIAN

\section{CHURCH}

\section{Foreign Missions \\ Home Missions}

The Reformed Presbyterian Church looks to Cedarville College for missionaries. Miss Martha Ramsey continues to do good work in Los Angeles and the Rev. Wm. Waide in India. The former received her collegiate training in Cedarville College and the latter is a graduate of Cedarville College.

Mr. Ralph S. Elder, a talented, scholarly, and consecrated young man has offered himself to the Board of Foreign Missions for service in India. These together with Mr. R. N. Colman, Jr., who also has offered himself, will make four missionaries from Cedarville College for our own church. The Board of Foregin Missions and the whole church will be glad to hear of others. 


\section{9}

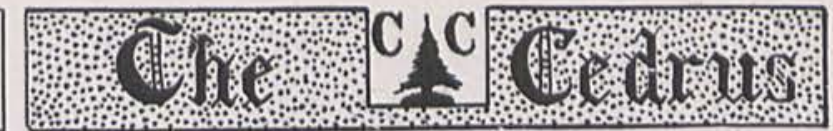

18

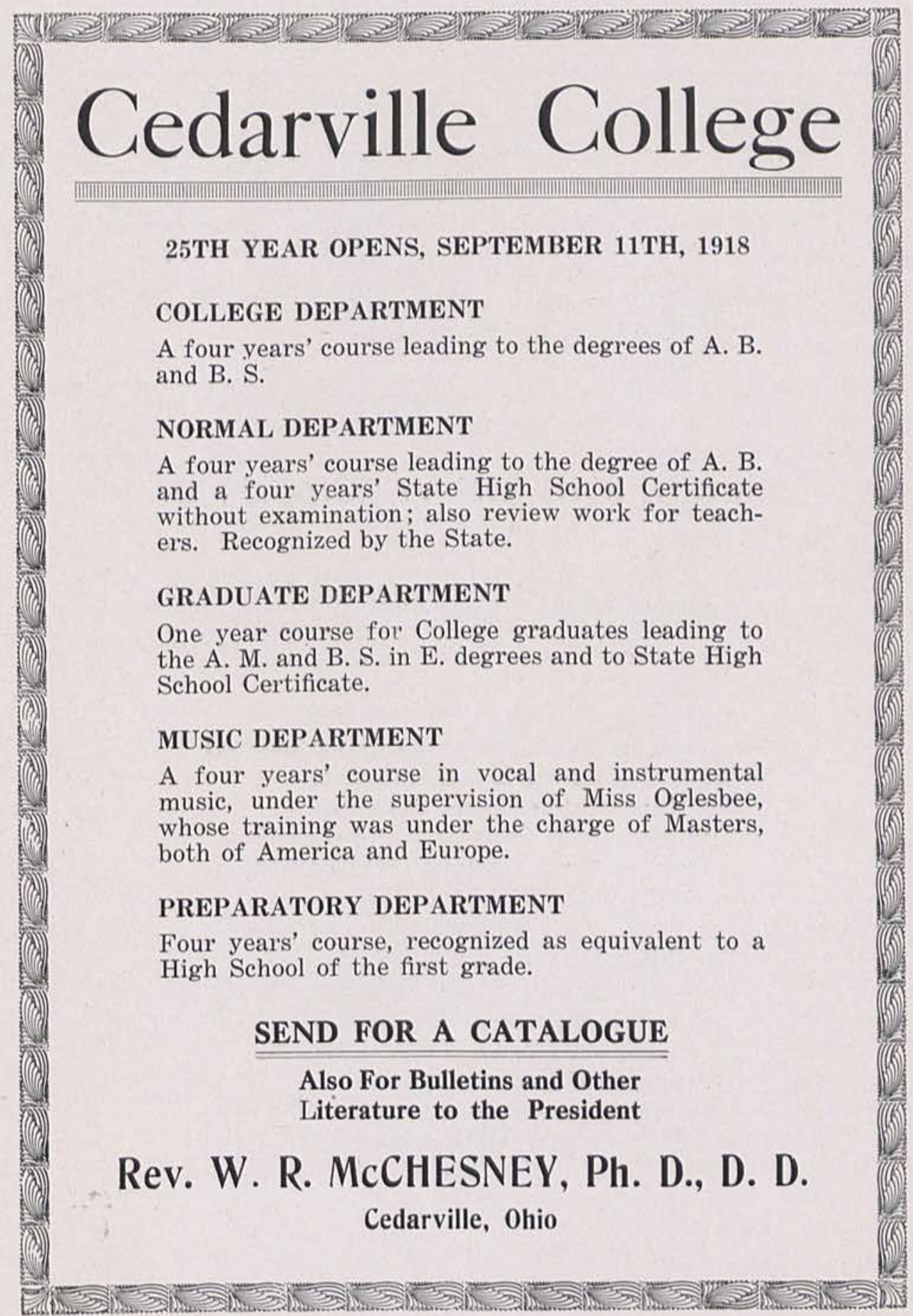




\section{9}
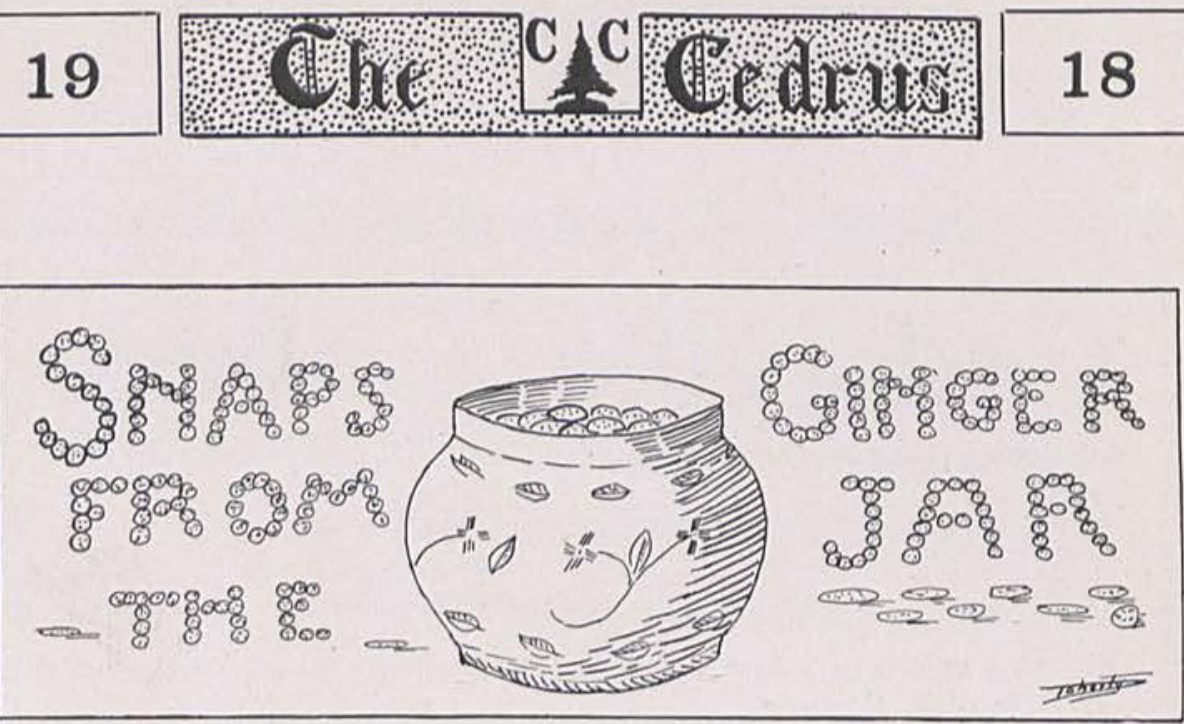

\section{SOLILOQUY ON VACCINATION}

Of all things in Science's creation

The most hideous of these is vaccination!

The decree came forth from a delegation

To do our bit- to help our Nation-

Stamp out a disease by acclamation.

And the method to be used was vaccination!

We looked for aid in concentration,

But there was no use in exhortation,

And the powers would make no alteration, And we could not depend on equivocation,

So finally in sheer desperation,

Like lambs, we submitted to the operation!

For this is the way of civilization.

But later the pain showed their location.

The doctors had made a defalcation

And all of our fears had crystallization, Till pale, at last in desperation

We took an unlooked-for vacation.

But back we came with decoration-

Thank heaven we're thru with vaccination.

A. Victim. 


\section{9}

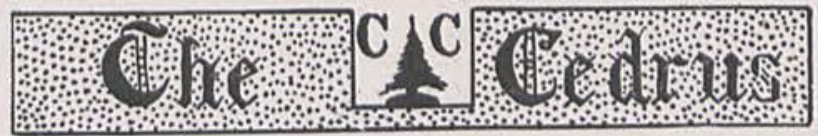

\section{FAVORITE SONGS}

I Don't Want to Get Well-Anderson.

Whose Pretty Baby Are You Now-Elwood.

When the Sun Goes Down in Cedarville and

The Moon Begins to Shine-Mildred M.

Good-Bye, Good Luck, God Bless You-Isaac.

Why Did You Make Me Love You-Stormont.

You Broke My Heart to Pass the Time Away-Thorn.

What Wonderful Things One Little Girl Can Do-Hammond.

Oh, Where Is My Wandering Boy Tonight-Ruth Harris.

Oh! Think of a Home Over There-Ruth Ramsey.

Sooner or Later (duet)-Morton and Ellen.

One Wonderful Night-Rebecca Marsh.

Wandering Thoughts (trunks)-Elwood.

Sympathy-Liming.

Memories-Hester Townsley.

Somewhere in France-Janet McClellan.

When You Come to the End of a Perfect Day-Eva Tarbox.

I'm Looking for a Girl Like Mother-Ralph Elder.

There Is a Quaker Down in Quaker Town-Doherty.

\section{EVOLUTION OF A C. C. STUDENT}

A woodpecker sat on a Freshman's head

And settled down to drill.

He bored away for an hour and a half,

And finally broke his bill.

A woodpecker sat on a Sophomore's head

And settled down to work

He bored away for one long hour

Unsuccessful-he did not shirk.

A woodpecker sat on a Junior's head, And still he did not go.

And he bored away for a half an hour

And an opening began to show.

A woodpecker sat on a Senior's head, And alas, 'tis sad but true

He bored away for a minute there, And then it went clean through. 


\section{9}

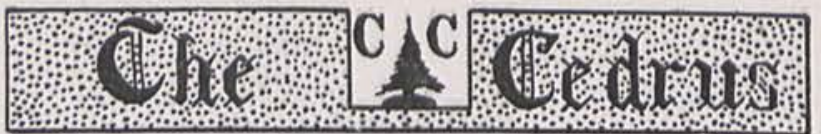

OUR COLLEGE ORGANIZATIONS

County Work House...

Miss Schneder's Room

County Jail

Prof. Bauman's Room

Police Court

Prof, Sloan's Room

Juvenile Court

Freshman Class

The General Assembly.

Chapel

"Bored" of Education

Student Body

Board of Control. ..Faculty

\section{FACULTY COMMENTS}

Dr. McChesney: The mildest manners and gentlest heart.

Prof. Allen: Rare compound of oddity, frolics and fun who relished a joke and rejoiced in a pun.

Miss Schneder: Her little body lodged a mighty mind.

Dr. Jurkat: None but himself can be his parallel.

Prof. Bauman: I never felt the kiss of love, nor maiden's hand on mine.

Prof. Sloan: His frown was full of terror, and his voice shook the delinquent with fits of awe.

\section{CLUB SAYINGS}

Miss Alexander: Why don't you get an alarm clock?

Mr. Elder: Save the sugar.

Elwood: Who made the holes in spaghetti?

Thorn: Please pass the Mash.

Mildred: Why don't we have some "jelly?"

Ida: We don't want onions on Friday night.

Prof. Bauman: That does not agree with my stomach.

Clark: Is there any more bread?

Chu: Where are my chop-sticks?

Margaret: Who wants my prunes?

Liming: Is breakfast ready?

Duncan: Why don't we have some "Olives?"

Rickenbach: Hurry up the supper; I've got to meet the train.

Cat: $\mathrm{M}-\mathrm{E}-\mathrm{O}-\mathrm{W}$. Who took the cream?

\section{CEDARVILLE'S OFFICE PERSONALITIES}

The Blotter: Retentive; absorbs a great deal-Helen Creswell.

The Diesk: Receptive, sympathetic; likes to be leaned on.-Jim Chesnut.

Ink Well: Extremely versatile; can write a wrong or wrong a right.-Paul Elwood.

The Paste Pot: Persistent, persevering, possessing the faculty of sticking to things. - Sherman Liming.

The Pen: Enterprising, ambitious, even waits an opportunity to make a mark.Bob Colman.

The Waste Basket: Intemperate, aggressive and is fond of scraps.-Nelson Thorn.

The Writing Table: Diminutive, quiet, can easily be covered.-Olive Northup.

The Calendar: Contemporaneous but lazy, always up to date but frequently takes a month off.-Doherty. 


\section{01}
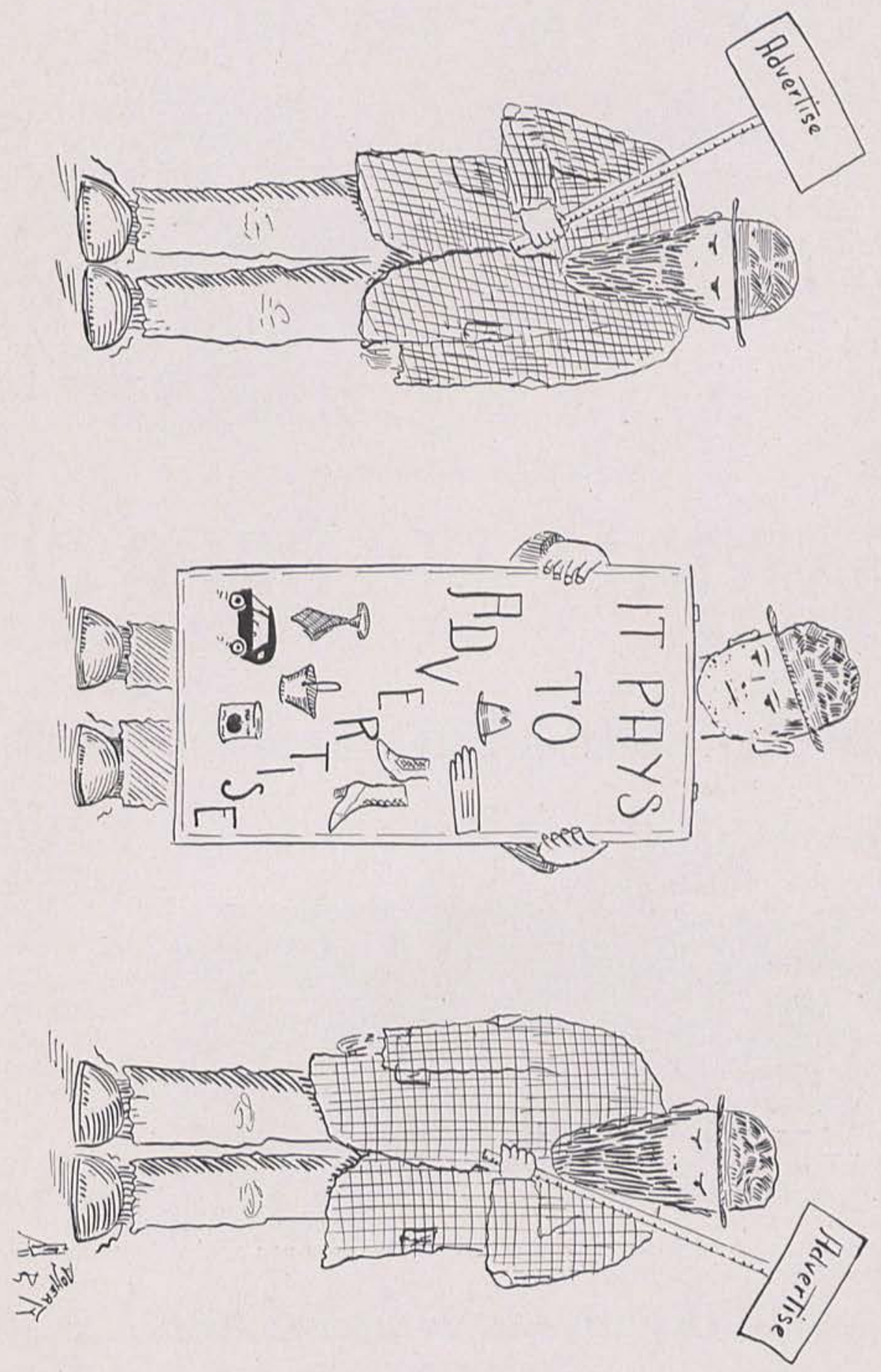

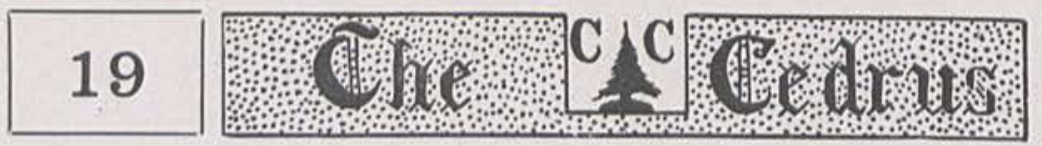

\section{8}

\section{Entertain Your Wife and Children}

with one of our player pianos of ultra-quality and of stupendous musical value. Our instruments help make the modern homes gracious and beautiful.

The player piano is a wonderful musical means for employing it.

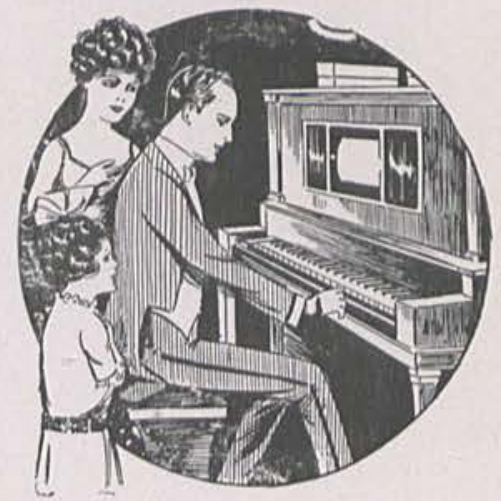

The best place at which to buy one is

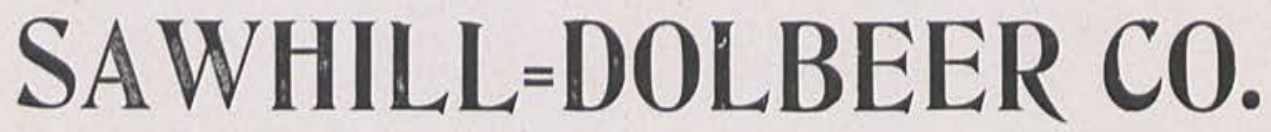

\section{RE0 $=$ HUPMOBILE $=$ OVERLAND $=$ DODGE $=$ HUDSON}

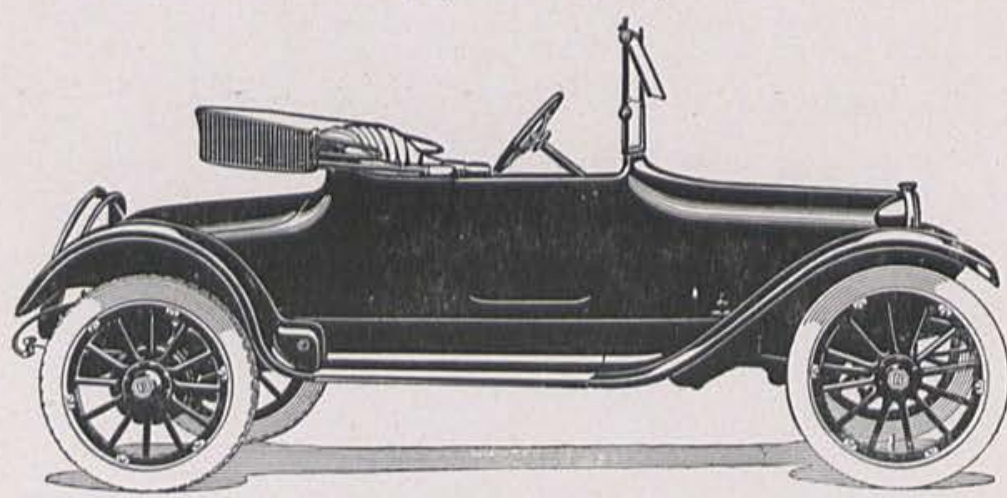

We have been in the business 15 years.

THESE are not assembled cars made in fifty different factories, but 1 cars manufactured in their own factories by responsible people and sold by companies who have been in the automobile business years and who take care of their customers after the cars are sold. Ask the people who have purchased cars from us.

\section{WICKERSHAM HARDWARE CO. Jamestown, Ohio}




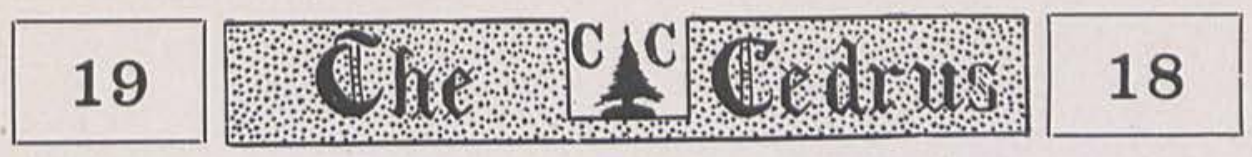

\section{My Enlargements Are the Best}

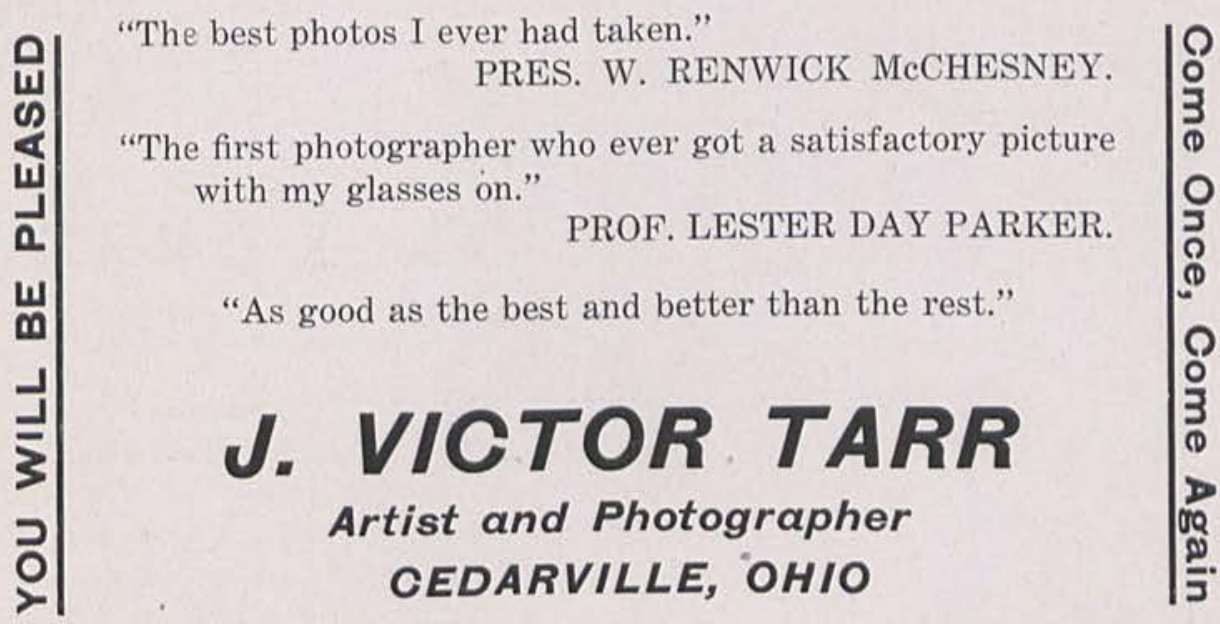

MY FRAMING IS THE NEATEST

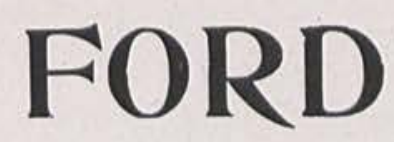

AUTHORIZED SALES AND SERVICE

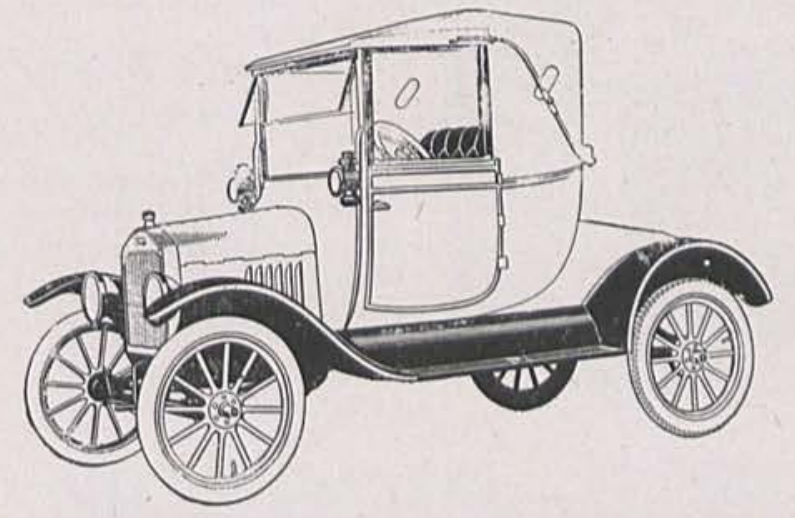

R. A. MURDOCK, ${ }_{\text {CHONE } 55}^{\text {CEDRVILLE, o. }}$ 


\section{9}

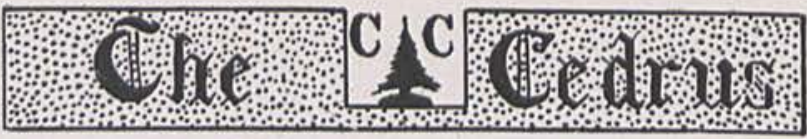

\section{"Quality First"}

There are lots of places to buy Good Furniture but ONLY ONE

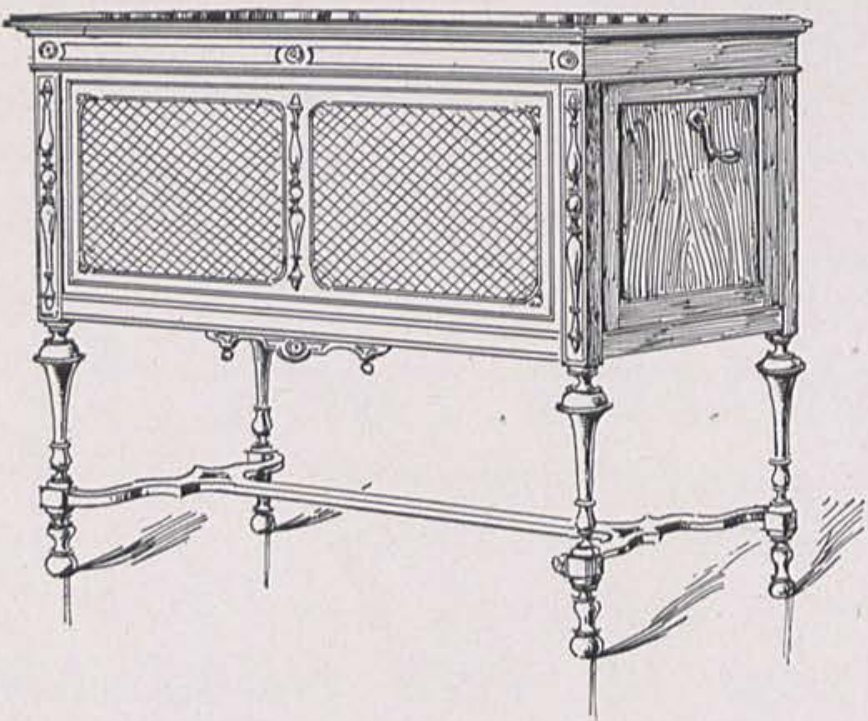

PLACE to BUY THE BEST

J. A. BEATTY \& SON

Dependable Furniture Xenia, Ohio

Agents for the "WINDSOR" Phonograph

Plays any make record

Mr. Hammond: "What do you charge for your rooms?" Miss Cooper: "Five dollars up."

Mr. Hammond: "But I'm a student."

Miss Cooper: "Then it's five dollars down."

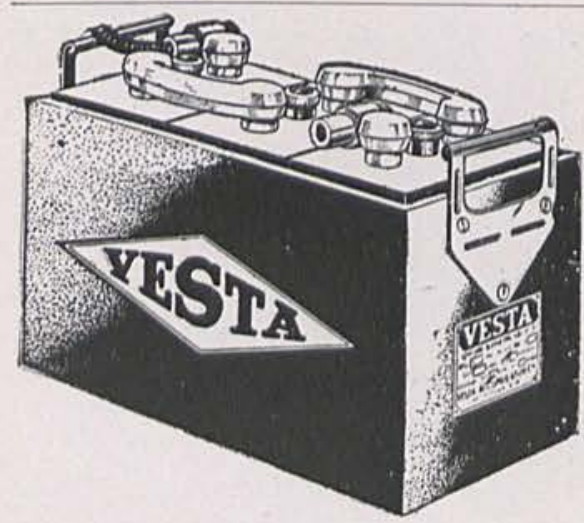

\section{VESTA}

Storage Batteries have double life

The wise investor buys a "Vesta" New Batteries in stock

We repair and recharge all makes of batteries

Wo have a rental battery that will fit your car

OSCAR L. PIDGEON

South Detroit St., Opp. Shoe Factory Bell Phone 98 Citizens 23

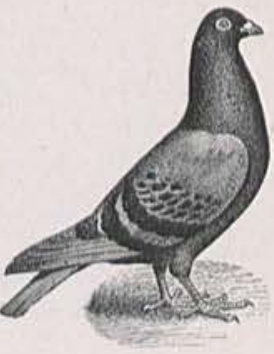




\section{9}

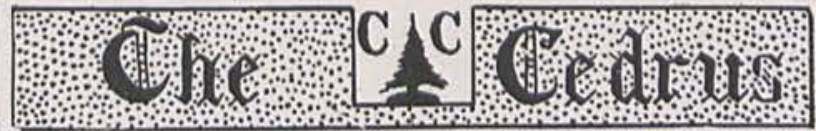

\section{Go to POST Bakery For Groceries and Liberty Bread}

We Substitute the Following:

Service for Sneers

Fconomy for Waste

Co-operation for Criticism
Production for Pessimism

Common Sense for Common Gossip

Greater Production for a German

We Ask Your Kind Patronage to Substitute Home Trade Exclusive

John Harvey was a rackety young man and kept very late hours, but he had now joined the Regulars and was ordered to the front, and on bidding farewell to his beloved said to her:

"Darling, when I am far away wilt thou gaze at yon star every night and think of me?"

"I will indeed, dearest," she replied. "If I need anything to remind me of you, I should choose that very star."

"Why?" he asked.

"Because it is out so late at night and looks so pale in the morning."

\section{THEOLOGICAL SEMINARY CEDARVILLE. OHIO}

The Theological Seminary of the Reformed Presbyterian Church offers regular three years' courses in Theology ; and combined courses in Collegiate and Seminary work of five years, leading to the degree of A. B.

For information apply to

REV. W. R. MCCHESNEY. PH. D., D. D. CEDARVILLE, OHIO 


\title{
19
}

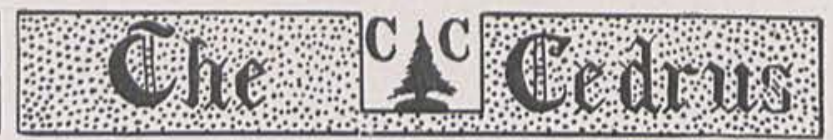

\section{STOP}

Come see what a DOLLAR will DO at a

Spot Cash Store

\section{W. W. Trout Grocery Co. CEDARVILLE, OHIO}

Senior: "I expect to have a very glowing future."

Freshman: "Yes, especially after you die."

Why did Paul raise a mustache before he proposed to Olive?

0 ! he wanted to keep a stiff upper lip if she turned him down.

With Ellen's hand upon the wheel,

I lounge, secure in her protection;

No fear of spills or jolts I feel-

She drives a Ford car to perfection.

\section{Swift's Company (Fertilizer) \\ Cleveland, Ohio}

"It Pays to Use Them"

\author{
LOCAL AGENT
}

\section{GEO. H. CRESWELL}

\author{
CEDARVILLE, OHIO
}



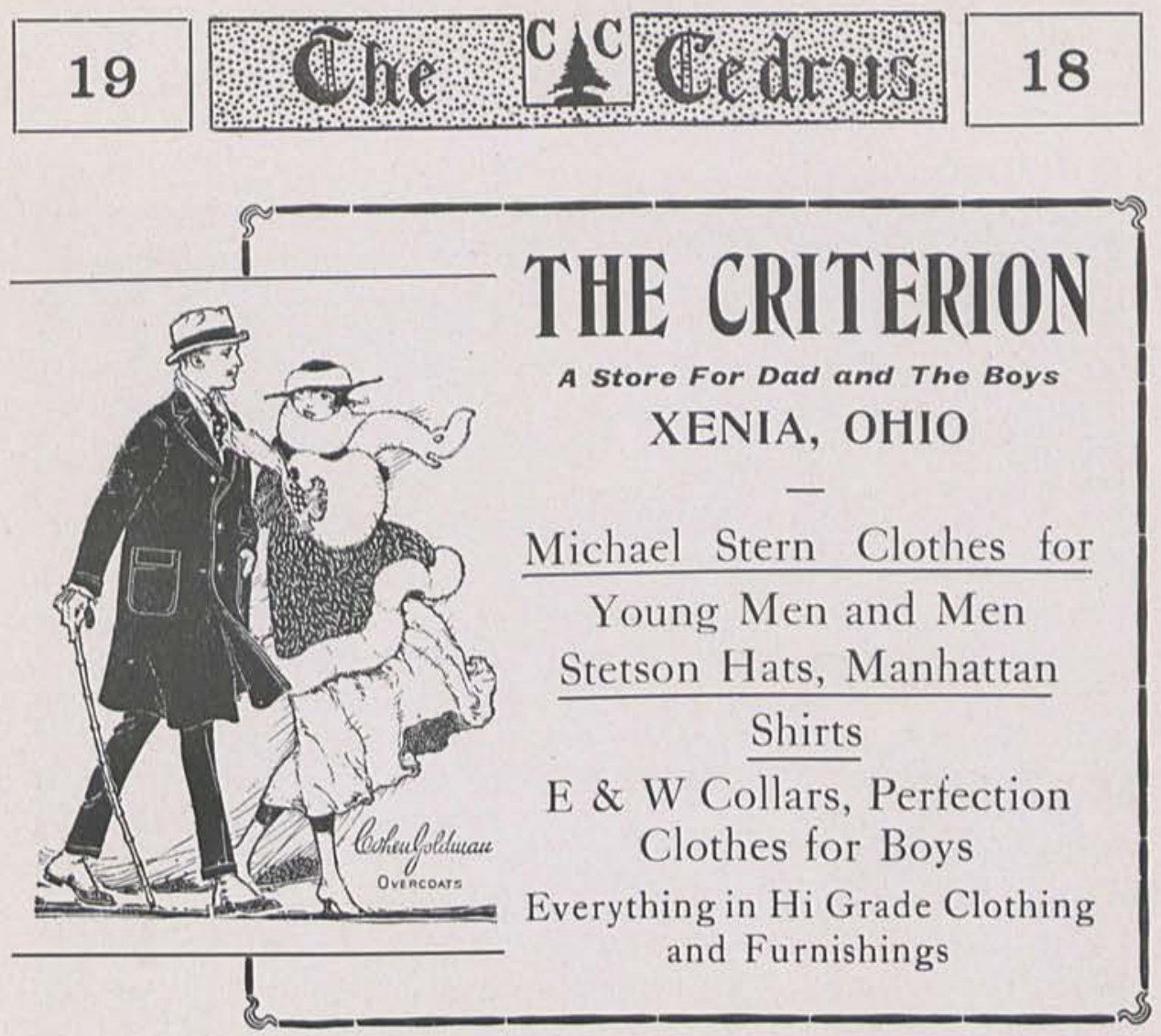

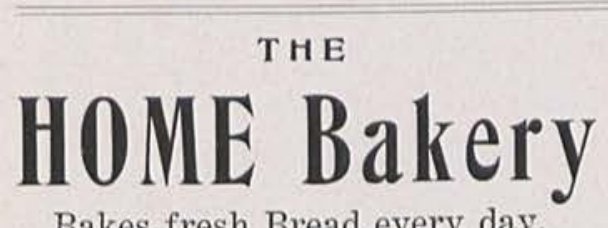

Bakes fresh Bread everv day. Delicious Pies, Cakes and Pastries a Specialty.

Delivery Every Day. JACOB SIEGLER

Phone 65 Cedarville, Ohio
When you want UP-TO-DATE PHOTOS call on

\section{CANBY}

Xenia's Leading PHOTOGRAPHER

34 E. MAIN ST. XENIA, 0.

The Cedarville Herald

ESTABLISHED 1878

\section{Commercial Printing of All Kinds}

Cedarville, Ohio 

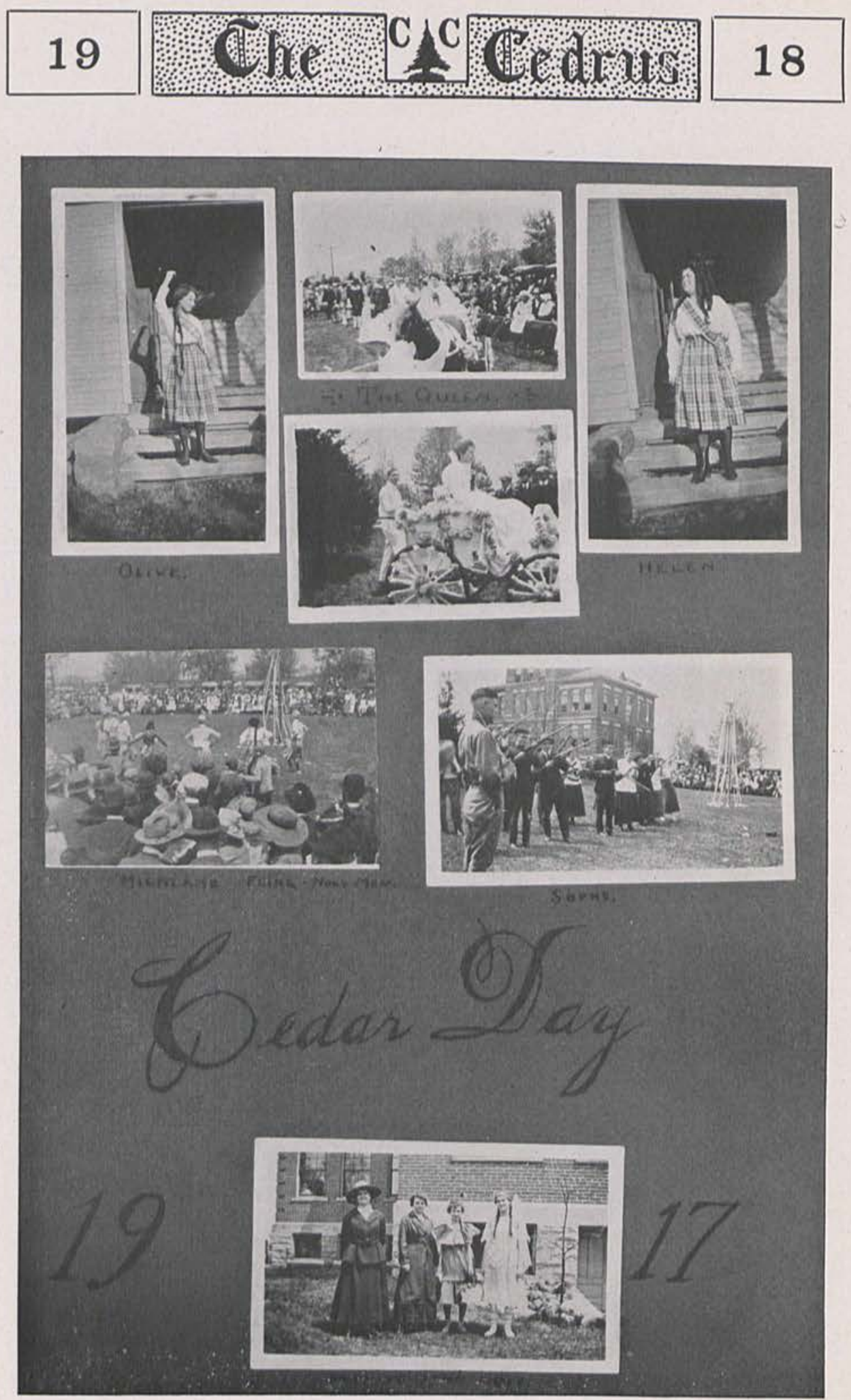


\section{9}

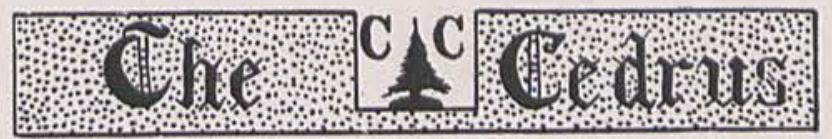

\section{8}

\section{The Tarbox Lumber Co.}

Have a complete line of BUILDING MATERIALS

Estimates cheerfully made. Best grades at

reasonable prices.

\section{Phone 33}

Cedarville, Ohio

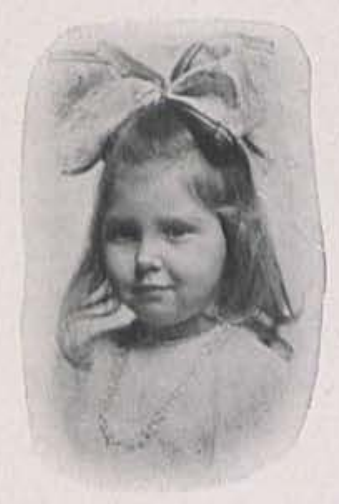

Most things can be anybody's gift-your portrait is distinctively, exclusively yours.

\section{Make that appointment today \\ The Wheeler Studio Xenia, Ohio}

Choose the instrument the world's greatest artists have chosen

Could you ask a safer guide? Certainly no one is better qualified to judge a musical instrument. They know music. Their life-work is music. And Melba, McCormack, Caruso, Farrar, Galli-Curci, Gluck, Homer and a host of other world-famed artists have chosen the Victrola to carry their superb art on Victor Records exclusively to all the world.

Victors and Victrolas $\$ 10$ to $\$ 400$. Call and let us give you a demonstration.

\section{Victrola

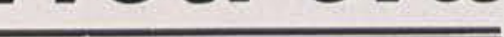

\section{R. D. Adair Xenia, Ohio}




\title{
19
}

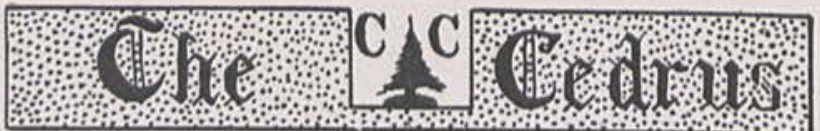

\section{FASHION PARK}

\author{
AND \\ HAR'T SCHAFFNER AND MARX \\ Suits and Overcoats \\ $\$ 22.50$ to $\$ 50.00$ \\ Clothcraft Clothes \\ $\$ 18.00$ to $\$ 25.00$

\section{A. WEA VER}

MAIN ST., OPP. GOURT HOUSE

XENIA, OHIO

\section{THE CEDARVILLE COLLEGE “AD” COLUMN}

Wanted-My Soldier Boy-Janet McClellan.

Wanted-A good "Wright" hand-Jim Chesnut.

Wanted-More work for my Poetry and Drama Class-Miss Schneder.

Wanted-More brains-The Freshman Class.

Wanted-More spreads-Sophomore Class.

Wanted-To appear as Seniors-Junior Class.

Wanted-A Book "To Make Him Understand"-Rebecca Marsh.

Wanted-Some real students-Prof. Sloan.

Wanted- $\$ \$ \$ \$ \$ \$ \$$ more $\$ \$ \$$-Prof. Jurkat.

Wanted-A girl-Duncan and Foster. *

Wanted-To know myself-Bob Colman.

Wanted-A diamond-Helen Oglesbee.

Wanted-Some one to love me-Margaret Elder.

Wanted-College "spirits"-Students.

Wanted-Freda-Bill Collins.

Wanted-Dates with a Senior Girl-Allen Turnbull.

Wanted-To live in Spring Valley-Patty Harris.

Wanted-A wedding dress-Marguerite Gilkey.

Wanted-A High School Prin.-Zelpha Dobbins, Clerk.

Wanted-An alarm clock, "Big Ben" preferred-Maud Goetting.

(* Other names appeared, but wants have been supplied recently-
ditor.) Editor.)

Compliments of

\section{Kerr \& Hastings Bros.}

Cedarville, Ohio 
TRADE US YOUR OLD PIANO FOR A PLAYER PIANO OR A COLUMBIA GRAFONOLA

CALL AND GET OUR PROPOSITION

\section{SUTTON MUSIC STORE}

New Location

Cor. E. Main and Whiteman Sts., XENIA, OHIO

\section{Rienarif́s' Drug Store \\ Students' \\ Headquarters}

Phone 203 Cedarville, Ohio
SEVEN CARDINAL SINS

1. Chewing gum in class.

2. Whispering on the sly.

3. Dragging your feet.

4. Talking in the halls.

5. Knitting in Biology.

6. A perfect recitation.

7. A pull with the Faculty.

Bell Phone 681

Citizens Phone 174

\section{FLOYD ANDERSON, FLORIST}

FLOWERS FOR ALL OCCASIONS

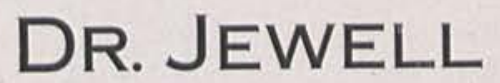

STEELE BUILDING XENIA, OHIO

\section{Galloway \& Cherry}

II East Main St.

Xenia $===$ Ohio

\section{Thorb Charters}

Jeweler

44 EAST
MAIN ST. Xenia, Ohio 


\section{9}

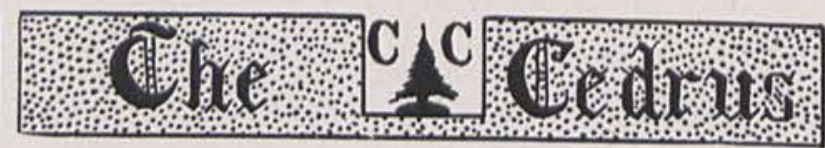

18

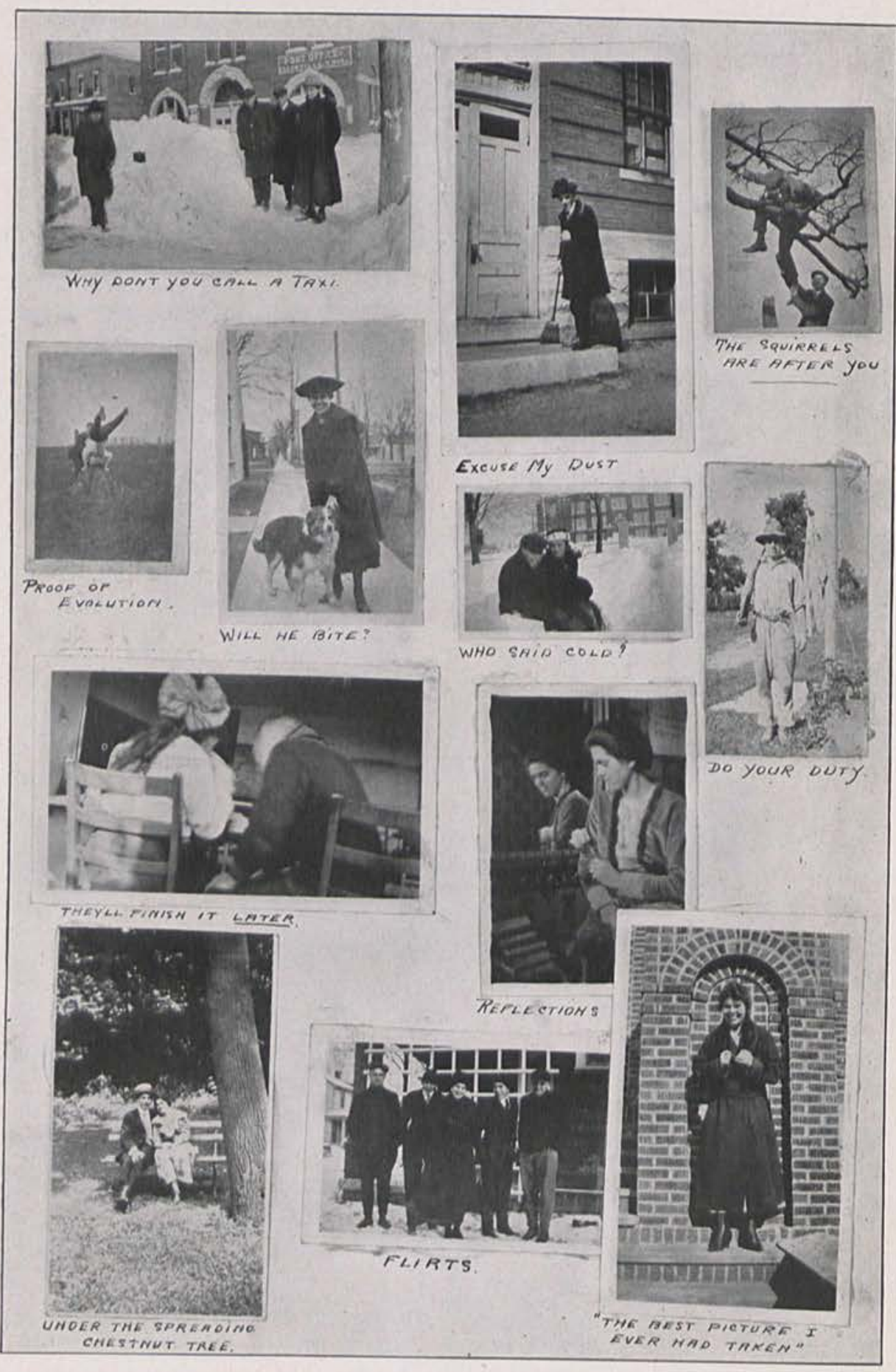



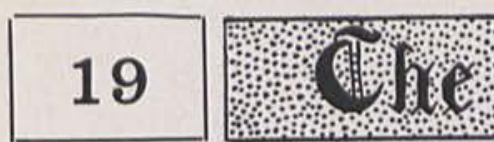

$1 \%$

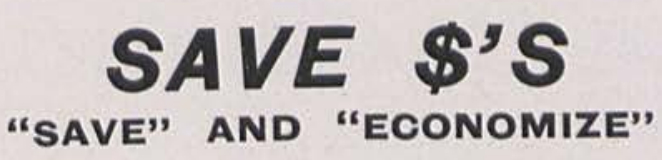

are the words of the hour. Our PROFIT SHARING PLAN will materially assist you in SAVING your \$'s in

\section{Clothing, Furnishing Goods \& Shoes}

We give you back $4 \%$ in Merchandise. Buy where RENTS and Running Expenses are LOW and SAVE your \$'s

\section{4\% \\ Home Clothing Co. TRADE AT HOME}

Both Telephones

010
J. H. WHITMER JOHNSON \& DEAN

FUNERAL DIRECTORS AND EMBALMERS

OFFICE OPEN DAY AND NIGHT

\section{HUTOHISON \& GIBNEY'S}

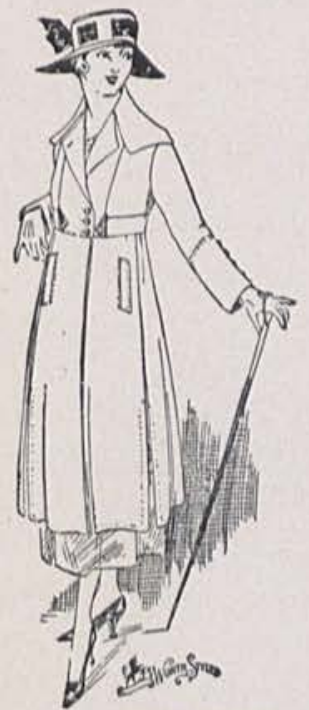

LARGEST AND
XENIA, OHIO

55 Years of Bargains

Silk-Table Linens

Rugs-Linoleum-Chinaware

Woodware-Curtains

Ready-to-Wear Suits, Coats, and Skirts

Percale Dresses-Corsets

Underwear.

BEST SELECTIONS THIS YEAR 

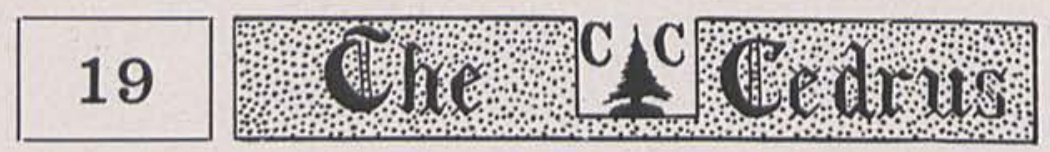

\section{8}

\section{ROBERT BIRD \& SONS CO.}

THE STORE THAT THE STUDENTS MAKE THEIR HEADQUARTERS

WE TRY TO PLEASE THEM

For the GIRLS

A full line of Furnishing Goods, Kid Gloves, Corsets, Silk Hosiery, etc.

\section{For All STUDENTS}

Tennis and Basket Ball Shoes,

Sweaters, Pennants, etc.

\section{For the BOYS}

Wilson Bro. Famous $\$ 1.50$

Shirts; Rice and Hutchins $\$ 5.00$ and $\$ 6.00$ Shoes; Royal Tailored Suits; Snappy, Stylish Hats and Caps; Nifty Neckties, Arrow Collars, P. Q. A. and Mentor Underwear, Silk Socks, Belts and other merchandise of merit.

We take this opportunity to thank all the students for their patronage.

$$
\text { COME AGAIN }
$$

\section{FOR SALE}

A perfectly good preacher, has had almost four months' experience. DOT SMITHSON.

A good cook, cheap, as I have moved and have no use for one.

HAROLD HAMMOND.

A dozen second-hand ladies' handkerchiefs, cheap.

NELSON THORN.

One "Pictoresca Espanol" as I have entered a partnership with a new firm. IDA REES.

A Reo automobile, price $\$ 25$. Owner moved near place of business.

A good photograph of Paul. BOB EDW ARDS.

Two hens, both of good blood, sisters won first prize at the Cedarville College Feed in 1918.

"THE BUNCH."

\section{The Missouri State Life Insurance Co. ST. LOUIS, MISSOURI} 1 HE Missouri State Life writes guaranteed contracts, with loan

Cash paid up, extended Insurance, and Loan Values the second year and every year thereafter.

The Policy contract has a provision in it for insuring Loans, provided the insured can give a certificate of good health. Then in case of death it cancels the Loan and the Policy is paid in full to the beneficiary. The Company closed 1917 with assets $\$ 14,-$ 142,052.49. Guarantee Fund to Policy holders \$2,708,397.65. Insurance in force, paid for basis, $\$ 129,199,279.00$.

\section{P. A. ALTLANT, General Agent Washington C. H., Ohio}




\section{9}

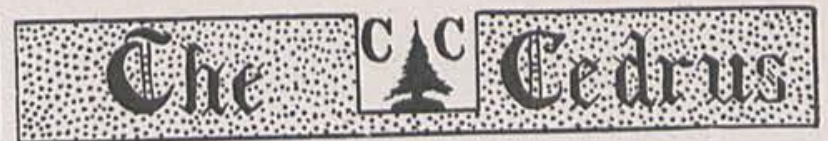

D. D. Doherty was heard to say that he would get a vacation if he got the measles.

The best way to give Dave a vacation would be to give him work. The change would do him good.

R. N. Colman spent a few days of his Xmas holidays at a hotel in Atlantic City. He wanted a rest and a change. The waiter got the change and the hotel got the rest.

Prof. McChesney (to class in Logic): "Remember class, that 'being' is anything that exists."

Mr. Elwood: "I have a question, Professor."

Prof. McChesney: "Very well, Mr. Elwood."

Mr. Elwood: "Since a being is a man and since a being is a pin, when a man is sitting on a pin, is the man being stuck? If so, what kind of a being is that?

\section{H. Bates \\ MEAT MARKET \\ Fresh and Smoked Meats \\ Phone 104 \\ Cedarville, Ohio}
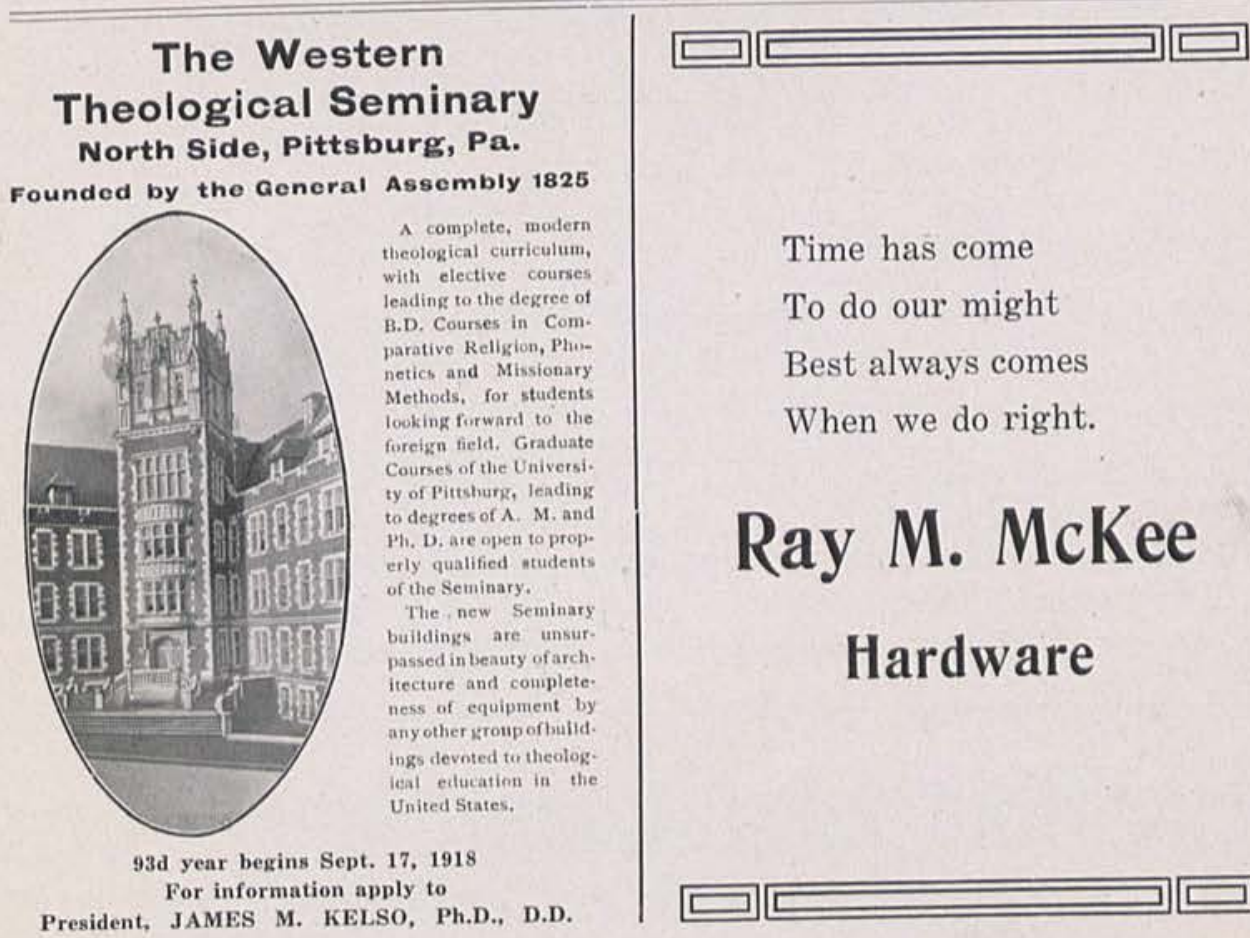

Time has come

To do our might

Best always comes

When we do right.

\section{Ray M. McKee}

\section{Hardware}




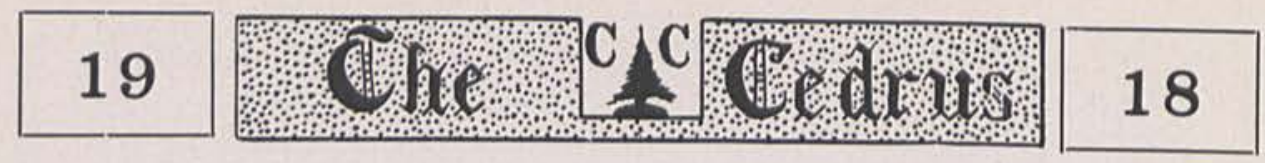

\section{Moore \& Ross Ice Cream}

The Best Cream of All Cream

Eat a Plate of Ice Cream Every Day

at

\section{A. J. Hinton's Restaurant}

\section{CEDARVILLE, OHIO}

Mrs. H.: "How can you stay away from home so late at night?"

Mr. H.: "O, easily, I acquired the habit while I was courting you, my dear."

$$
\text { (HEAD WORK) }
$$

He: "How does she get such high marks?"

She: "Takes all her subjects under instructors, smiles at them and calls them 'Doctor'."

\section{REAL PATRIOTISM}

Mary had a little bond,

She bought it for a dollar;

And when she clips the coupons off,

She makes the Kaiser holler.

Prof. Sloan: "Is a journey longer, or shorter, the first time you take it?"

Miss Elder: "That depends on whom you are with."

(We wonder how far she thinks it is to the cemetery.)

\section{The Ohio Educational Supply Co.} PAINESVILLE, OHIO 


\section{9}

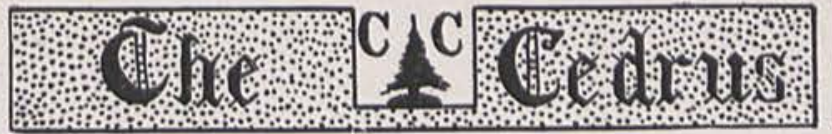

W. L. CLEMANS

REAL ESTATE, LOANS

$A$ N D

INSURA NCE AGENGY

Established 1896

GEDARVILLE, OHIO

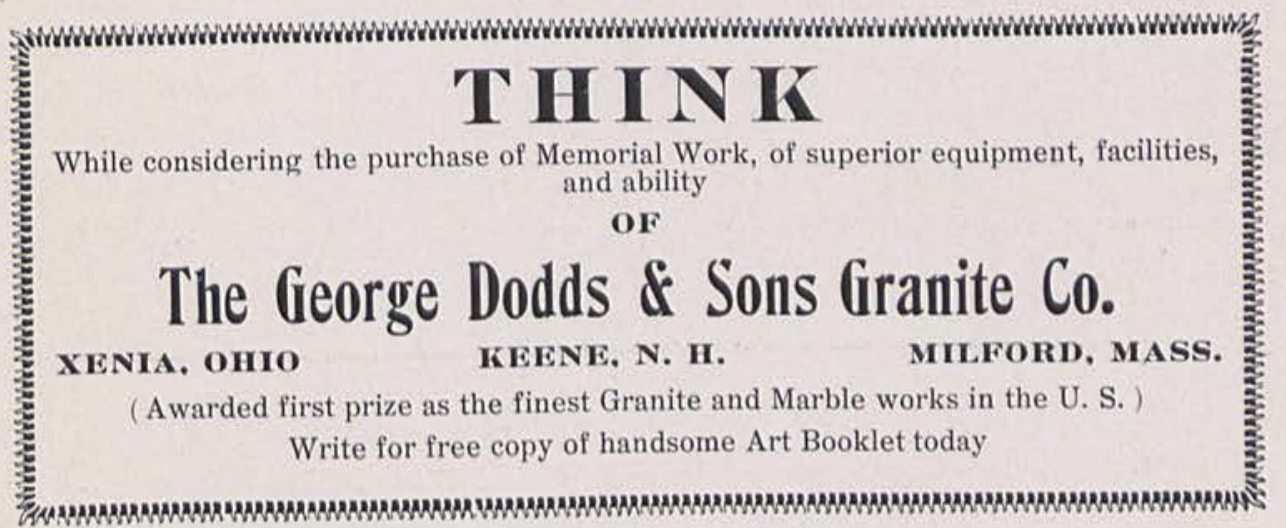

\section{BASTIAN BROS.,}

Manufacturers of

Class Emblems

Commencement Invitations

1036 Bastian Bldg
Rings

Programs
Athletic Medals

Visiting Cards, etc.

ROCHESTER, NEW YORK

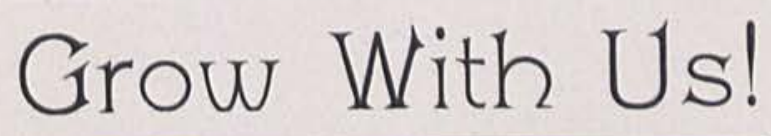

Place your savings with us on which we pay $4 \%$ interest compounded semi-annually

\section{THI EXCHANGE BANK \\ GEDARVILLE, OHIO}

GAPITAL AND SURPLUS $\$ 65.000 .00$
RESOURGES AND LIABILITIES $\$ 300,000.00$ 


\section{9}

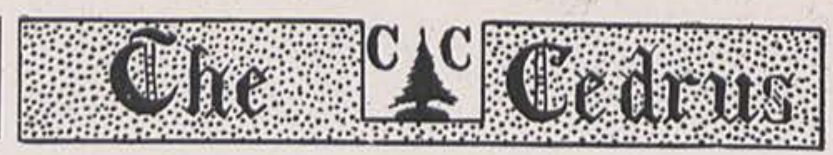

18

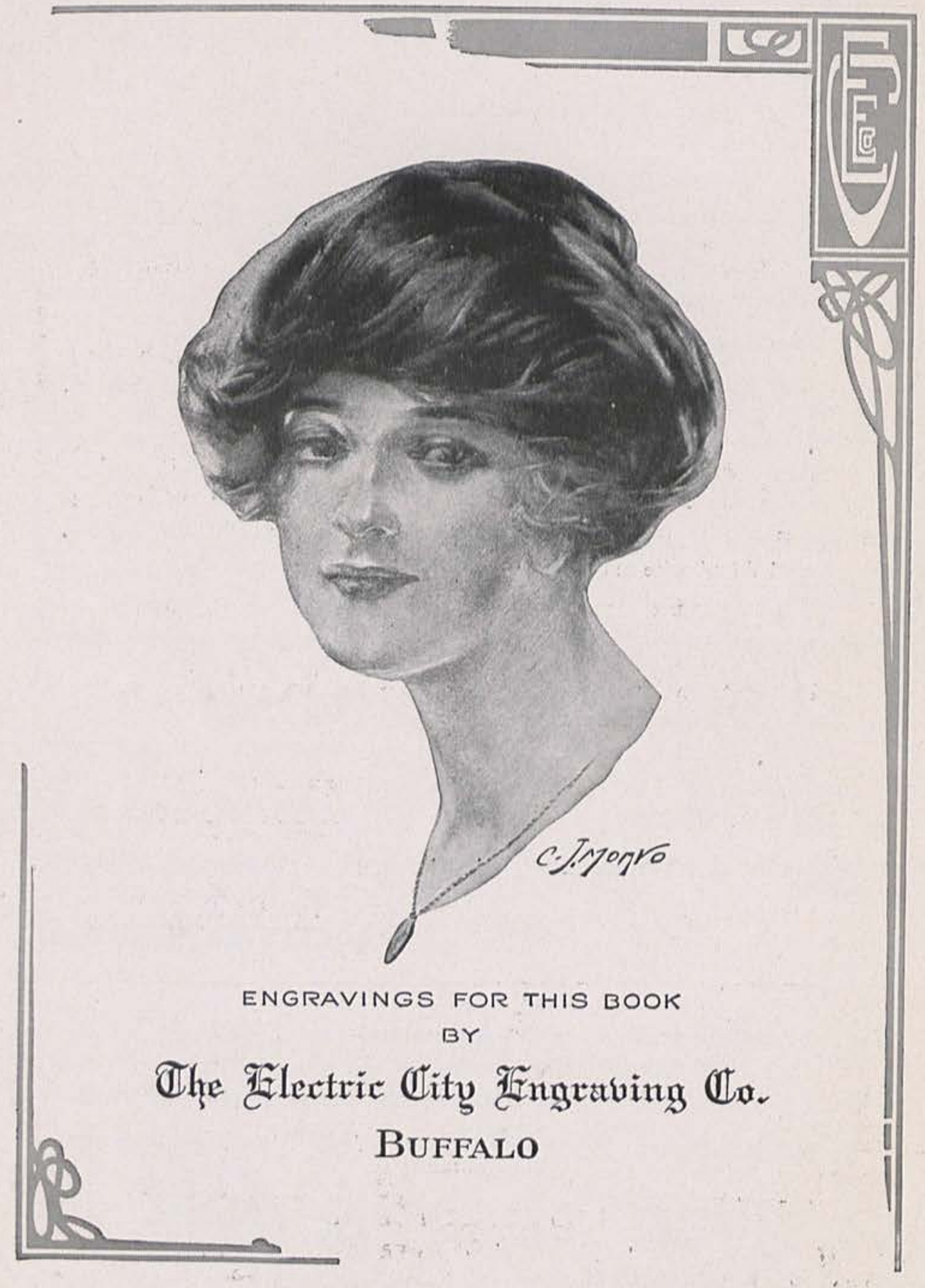




\section{9}

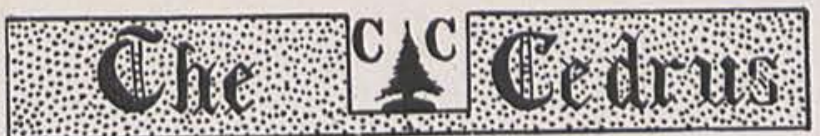

18

\section{Printers of this Annual}

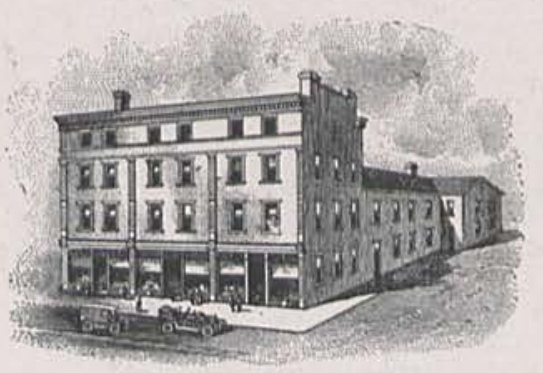

\section{The}

\section{Aldine Publishing House}

Geo. I. Graham \& Co.

College Publications

Printing - Fingraving - Binding

Samples and Prices on Request

19-23 S. Detroit St. Xenia, Ohio 


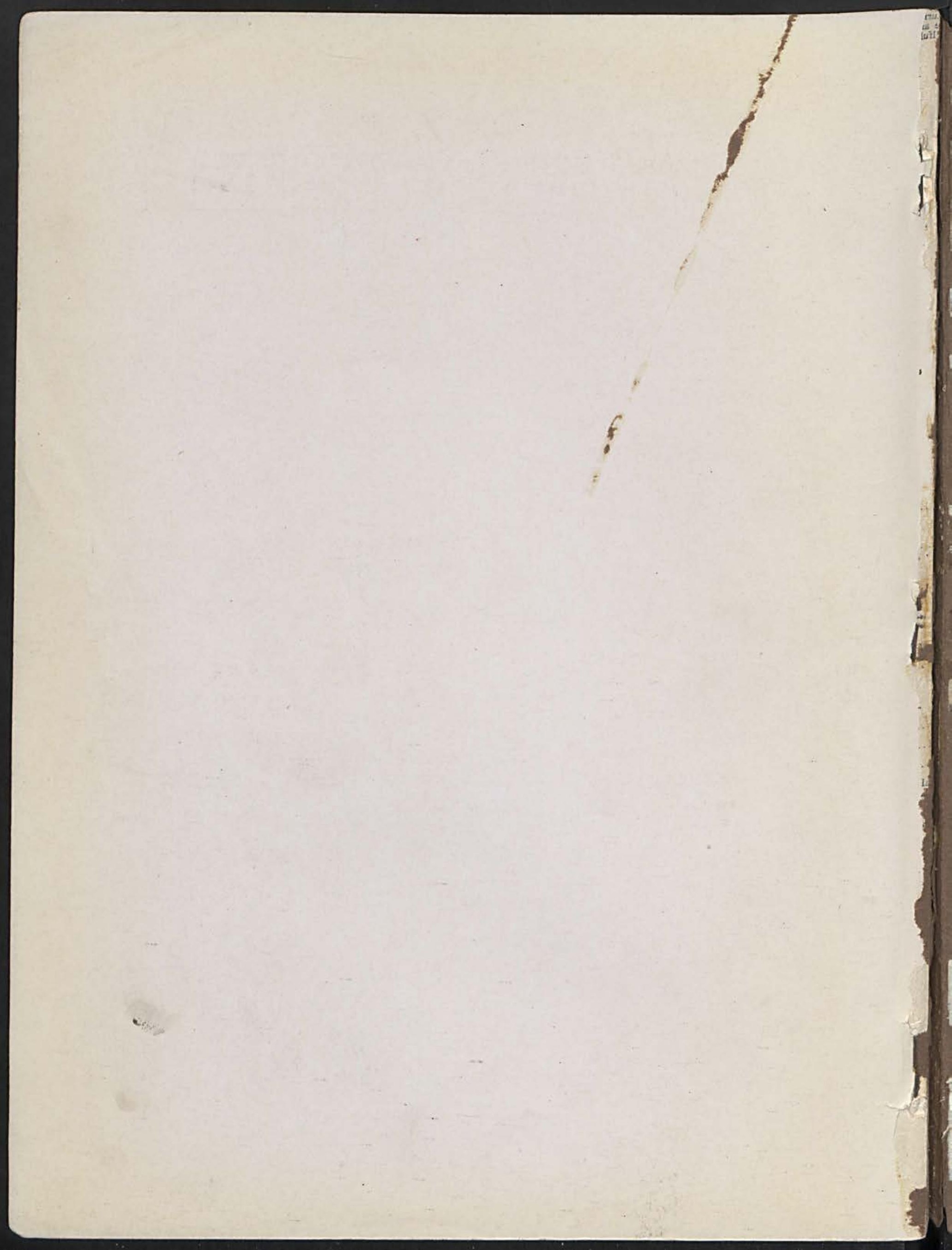




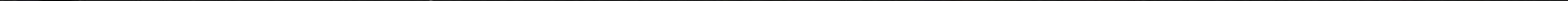


